A Journal of Agricultural Science Publisbed by the California Agricultural Experiment Station

BREEDING FOR RESISTANCE TO ONION DOWNY MILDEW CAUSED BY PERONOSPORA DESTRUCTOR

H. A. JONES, D. R. PORTER, and L. D. LEACH

\title{
A GENETIC ANALYSIS OF RED SEED-COAT COLOR IN PHASEOLUS VULGARIS
}

FRANCIS L. SMITH 


\section{A GENETIC ANALYSIS OF RED SEED-COAT COLOR IN PHASEOLUS VULGARIS \\ FRANCIS L. SMITH}





\title{
A GENETIC ANALYSIS OF RED SEED-COAT COLOR IN PHASEOLUS VULGARIS ${ }^{1,2,3}$
}

\author{
FRANCIS L. SMITH4
}

\section{INTRODUCTION}

SEVERAL VARIETIES of red beans are grown commercially in California. The market grades of these beans are determined largely by variations of the red color. The red changes to brownish red and brown after a year or two of storage. The occurrence of brown beans in these red varieties is considered by the trade to indicate old beans. Some varieties, especially Red Kidney, are easily discolored by the sun during the harvest so that occasionally newly threshed beans appear to be a year old.

The present study is a genetic analysis of red seed-coat color in the common bean (Phaseolus vulgaris L.) preliminary to a breeding program that might result in the introduction of factors that would stabilize the color of the Red Kidney variety. Commercial conditions are adverse to the introduction of varieties with new colors. The breeding problem, then, resolves itself into making more fast the red color without altering it. The ideal may be visualized as a color between the normal red and a darker red, and it was hoped that such an intermediate type could be developed. Crosses were made between red beans of several varieties. This paper reports the results obtained from these experiments.

\section{REVIEW OF LITERATURE}

The common bean is world-wide in distribution and is represented by hundreds of horticultural varieties with scores of seed-coat colors and a number of patterns of distribution of color. The species hybridizes easily. Therefore there is little wonder that the literature on the genetics of this species is voluminous and polylingual. Since different workers used different varieties and described the colors by various standards there is little wonder that the results, too, are variable and often apparently contradictory. There is no standard usage of symbols for the genes which have been analyzed; the same symbol has been used to mean a number of different characters. Beans were used by a number of the

\footnotetext{
${ }^{1}$ Received for publication June 21, 1938.

${ }^{2}$ Submitted in partial fulfillment of the requirements for the degree of Doctor of Philosophy.

${ }^{3}$ Assistance in planting, harvesting, and assembling data was provided by the Works Progress Administration, project nos. 433, 6129, and 8073.

"Junior Agronomist in the Experiment Station.
} 
early hybridists including Mendel (15). ${ }^{5}$ No attempt will be made here to unravel all the complications and disagreements extant in the literature. This task was undertaken by Kooiman (7) in his monograph on the genetics of the genus Phaseolus. Reference will be made, however, to earlier workers on those genes encountered in the present studies.

White Color.-Tschermak (26-29) was first to report on the white character. In crosses between colored and white beans he assumed a basic factor necessary for color. Later he (30) proposed the symbol $A$ to represent the presence or absence of this factor. Shull (22) used the symbol $P$ for yellow or brown pigment and $p$ for white; and Emerson $(2,3)$ used the same symbols to represent presence or absence of pigment. In his monograph, Kooiman ( 7 ) used the $A$ symbol to represent the presence of the primary color gene ; later workers $(9,17)$ have resorted to the use of $P$. Since the symbol has priority rights this gene will be referred to as $P$ in this paper. The conception of $P$ is that of a fundamental color gene which of itself gives no color. Thus two types of white beans are possible : $p$ whites lacking the fundamental color factor and $P$ whites which lack any complementary color genes. This will explain the results of Shaw and Norton (20) who obtained colored $\mathrm{F}_{1}$ plants by crossing two white varieties. Lamprecht (12) has obtained $P$ white experimentally. Most white varieties, however, are $p$ white.

Mottling.-The early workers were greatly concerned with the mottling character. From their results it soon became apparent that there were at least two genetic types of mottling-constant and inconstant.

Some bean varieties are mottled and this is a true breeding character. Tschermak (28) showed that mottling was a simple dominant in crosses between mottled and self-colored varieties. He considered the mottling distinct from the color genes. Shull (22) designated the symbol $M$ for mottled beans and $m$ for self-colored. This type of mottling has been studied by a number of workers. Another type of mottling which is similar in breeding behavior was reported by Tjebbes and Kooiman (25). The striping factor found in Cranberry beans they thought restricted the expression of the red color to stripes. It was given the symbol $S$. In a later paper Tjebbes (24) reported strong linkage between $S$, $B$, and $R$, the latter two being genes for seed-coat color.

Tschermak (28), Emerson (2), Shull (21) and numerous other workers found another type of mottling which was somewhat baffling. Its general characteristics may be seen by the breeding behavior of some crosses. Self-colored $\times$ self-colored gave mottled $F_{1}$; and $F_{2}$, ratio was 1 mottled: 1 self-colored. Self-colored $\times$ some white varieties gave mot-

\footnotetext{
"Italic numbers in parentheses refer to "Literature Cited" at the end of this paper.
} 
tled $\mathrm{F}_{1}$; and in $\mathrm{F}_{2}$ the ratios were 3 mottled: 3 self-colored: 2 white. Emerson (2) called this type of mottling $X$-mottled in contrast to the true-breeding $M$ type. Later he (3) proposed two closely linked genes $Y$ and $Z$ as being responsible for both types of mottling. In the mottled varieties both genes were present as dominants $P Y Z$. Self-colored races, each with one dominant and one recessive, when crossed would give the inconstant mottled type. For instance, $P y Z$ (self-colored) $\times P Y z$ (self-colored) would give a mottled $\mathrm{F}_{1}$, namely $\frac{P}{P} \frac{y Z}{Y Z}$. The $\mathrm{F}_{2}$ from such a cross would segregate into $1 \frac{P}{P} \frac{y Z}{y Z}$ (self-colored) $: 2 \frac{P}{P} \frac{Y z}{y Z}$ (mottled) $: 1$ $\frac{P}{P} \frac{Y z}{Y z}$ (self-colored). The genotype $P y z$, he thought, carries no mottling factors. White beans could carry any combination of mottling factors in a latent condition. Since the $y Z$ and $Y z$ were completely linked, the breeding behavior is the same as expected for a single heterozygous gene. No crossing-over was ever observed between these two hypothetical genes, so their existence could not be proved. Kooiman (6) offered a more likely theory of inconstant mottling. A bean with a heterozygous color gene $B$ is mottled. When homozygous for $B$ the color is darker, and when homozygous for $b$ it is lighter. To conserve space homozygous genes will here be represented by a single symbol and heterozygous by the symbols for the dominant and the recessive allelomorphs. The reaction of the $B$ gene can be shown in a single case taken from Kooiman's monograph (7) : $P B C=$ coffee brown, $P B b C=$ coffee brown mottled, $P b C=$ sallow yellow.

Kristofferson (8) used the symbol $K$ to represent the same thing: $P K=$ black ; $P K k=$ black mottled ; $P k=$ steel gray. This type of mottling has been worked out in great detail by Lamprecht (9-12). The color gene which causes mottling when heterozygous he called $C$. It also acts as a modifier in the presence of other color genes. Its action is illustrated in the following zygotic genotypes where mottling is indicated by a slant-line fraction, with the darker color as the numerator and the lighter color as the denominator: $P C J G B=$ argus brown ; $P C c J G$ $B=$ argus brown/buckthorn brown; and $P c J G B=$ buckthorn brown. Likewise, $P C J=$ chamois ; $P C c J=$ chamois/raw-silk yellow; and $P c J=$ raw-silk yellow. And finally, $P C=$ sulfur white $; P C=$ sulfur white/white ; and $P c=$ white.

In a later paper Lamprecht (14) presented data from a cross between Canadian Express and de la Chine. The color of the former was dark plum violet to Bordeaux red; the latter was sulfur white, which was 
shown in previous experiments to be $P C j g b v$. The $\mathrm{F}_{1}$ was weakly mottled, plum violet/chamois. This mottling could not be due to $C c$ because $P C j$ is sulfur white and $P c j$ is white. He supposed that the heterozygous gene pair $R r$ was the cause of mottling. The color reactions observed in $\mathrm{F}_{2}$ and $\mathrm{F}_{3}$ were : $P C J R$, dark plum violet; $P C J R r$, dark plum violet/chamois ; $P C J r$, chamois ; $P C j R$, light lilac ; $P C j R r$, light lilac/sulfur white; and $P C j r$, sulfur white.

Red Color.-Shaw and Norton (20) first called attention to red color inheritance in beans. They recognized two color series, the yellow-black and the red caused by anthocyanins which they represented by $\boldsymbol{M}$ and $M^{\prime}$ respectively. Further red modifiers were postulated: $E$ for purplish red as in the variety Mohawk, and $D$ for light red as in Red Valentine. The supposition of the $M$ and $M^{\prime}$ factors seems superfluous in the light of more recent work. Tjebbes and Kooiman (25) used three genes to account for the color in Cranberry beans, namely, $R, B l$, and $Z$. Their interactions were represented as follows : $R r$, pale red; $R$, red; $R, Z$, brownish black ; $R r B l$, violet ; $R b l$, purple ; $R r B l Z$, bluish gray ; $R B l Z$, black. The color due to $r$ only was not indicated. Tjebbes (24) described wine red as $R c$ and Burgundy red as $R C$. The genes $R$ and $S$ ( $S$ for striping) were linked with about 1 per cent crossing-over. Reference has already been made to Lamprecht's (14) red gene and its phenotypic expression. In some of the crosses reported in the present paper there is segregation for a gene which is similar to Lamprecht's (14) $R$ because beans heterozygous for this red gene are mottled. Therefore the symbol $R$ is used, assuming it is the same gene as Lamprecht's $R$.

Gloyer (5) reported progeny tests from a cross, White Kidney $\times$ Red Kidney. He made no attempt to analyze the genetics of color, but merely presented his data. Since his data support those obtained in this work they will be summarized later. The red color of Red Kidney behaved as a recessive, the dominant allelomorph being buff. This gene will hereafter be designated as $R k$.

Eyed Beans.-Emerson (3) studied the heredity of partial color in beans. Self-colored $\times$ eyed, gave self-colored in the $F_{1}$; and in the $F_{2}$ they segregated into 3 self-colored : 1 eyed. White $X$ eyed gave self-colored in the $F_{1}$, and in the $F_{2}$ they segregated into 9 self-colored: 3 eyed : 4 white. He postulated two genes, $P$, the primary pigmentation factor, and $T$ a gene which restricted color to the area about the hilum. The interaction was $9 P T$, self-colored: $3 P t$, eyed: $4 p$, white. In addition, he proposed the symbol $E$ for self-colored, and $e$ for eye pattern. Tschermak (30) used the symbol $Z$ to represent this pair of genes. Surface (23) grew progenies from natural hybrids between New Improved Yellow 
Eye (large-eye pattern) and Old Fashioned Yellow Eye (small-eye pattern). The $\mathrm{F}_{1}$ was piebald, with the color irregularly dispersed over most of the seed. In $\mathrm{F}_{2}$ he observed 146 piebald : 50 large eye : 70 small eye. He thought the low number in the large-eye class was due to linkage of the pattern factor and a lethal; but his hypothesis was not proved. If the data are fitted to a $2: 1: 1$ ratio by $\chi^{2}$ goodness of fit test, the probability value is .12. The secondary assumption therefore seems ungrounded. The results of Shaw and Norton (20) were explained by Emerson's (3) $P T$ hypothesis. Sax (19) believed the eye pattern was due to a double recessive condition for $t$ and $e$, because white $X$ eyed gave an $\mathrm{F}_{2}$ which fitted the ratio of 45 colored: 3 eyed : 16 white better than it did a $9: 3: 4$ ratio. Miyaki, et al., (16) crossed two partially colored types, saddle $\times$ bald, and in $\mathrm{F}_{2}$ obtained a ratio of 12 bald: 3 saddle: 1 eyed. Lamprecht (13) found five genes responsible for twenty-two partial color patterns. These genes were independent of four color genes. In pattern his partial-colored types varied from a dot on either end of the hilum scar to almost complete self color. The dot type was due to the recessive condition of the bip (bipunctata) gene; the dominant Bip had a "virgarcus" pattern. In the experiments reported in this paper there is but one eye pattern which is similar to Lamprecht's "virgargus" (plate 1 , figs. 34, 35). It will be represented by the symbol $E$ (self-colored) and $\boldsymbol{e}$ (eyed) following Emerson's (3) nomenclature.

Colored Hilum Ring.-According to Lamprecht (12) three color genes also color the hilum ring in the presence of the ground factor $P$. These are $B, J$, and $G$. Prakken (17) also noted colored hilum rings with his genes, $S, C$, and $V$ (probably identical to Lamprecht's $B$ ). In the studies reported here segregation for hilum ring was found only in some crosses involving the variety Mexican Red which has a black hilum ring.

\section{MATERIALS AND METHODS}

The crosses made to provide material for genetic analysis involved varieties of red beans, mottled beans that were predominantly red, white beans, and derivatives from these crosses. In the hybrids it was soon found that some standard of color must be employed to designate the different tints and shades. Ridgway's (18) Color Standards and Color Nomenclature was used. In order to save time in matching, each time a new color type appeared it was matched with the color book and a specimen sample placed in a Riker mount and labeled with the color name; the beans in each progeny were then matched with the type specimens. These standards represented modal classes, allowing for slight variations. The distinguishable colors are more numerous than the pheno- 
types so that the grouping of several closely related colors is necessary to avoid confusion in studying the actual phenotypes. This becomes apparent in $\mathrm{F}_{3}$ progeny tests made from beans which were classified for color in $\mathrm{F}_{2}$.

The varieties used in these crosses together with the author's accession numbers were :

\author{
Red Kidney 4370 (plate 1, fig. 1) \\ Red Kidney 4395 \\ Geneva Red Kidney 4387 \\ Nagazura 4390 (plate 1, fig. 2) \\ Speckled Kidney $50(51) 30$ (plate 1 , \\ fig. 5) \\ Long Roman 4521 (plate 1, fig. 3) \\ Red Eye 4387 (plate 1, fig. 34) \\ White Kidney 4516 (plate 1, fig. 33)
}

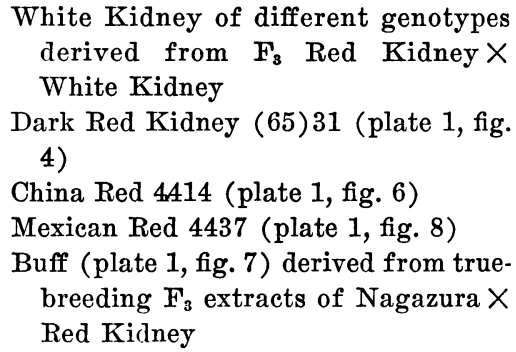

\section{RESULTS}

In this discussion of results the colors of mottled beans are written as a fraction as explained in the section "Review of Literature"; this usage has already been accepted in the literature as indicating mottling. In the tables the zygotic genotypes are represented as follows : heterozygous genes are shown as a fraction, the dominant allelomorph as the numerator and the recessive as the denominator; homozygous genes, either dominant or recessive, are represented by a single symbol. This method makes it easier for the reader to see which genes are segregating. The $\chi^{2}$ method was used as a measure of goodness of fit. The probability values $(P)$ shown in the tables were taken from Fisher's table for the $\chi^{2}$ values (4). Interpolations of probability were made for $\chi^{2}$ values which were intermediate between any two values given in the table.

The genetic analysis of the crosses made are discussed in the following paragraphs. Each cross is treated separately and where possible the genotypes of the parents are indicated by symbols in the topic heading.

\section{NAGAZURA $\times$ RED KIDNEY}

(Formula: $P M R k b l \times P m r k B l$ )

Nagazura is a red/buff mottled bean (plate 1, fig. 2). The $F_{1}$ was purple/buff (plate 1, figs. 9, 10,11). It is assumed, therefore, that the Red Kidney (plate 1, fig. 1) carries a gene which changes the red in a mottled bean to purple. This gene is similar in action to the $B l$ described by Tjebbes and Kooiman (25) and will therefore be designated by this symbol. In the presence of the recessive $b l$, mottled beans are red-mottled. Since both these varieties are colored, they both carry $P$. Nagazura 
carries $M$, the mottling gene. In the $\mathrm{F}_{2}$ only two self-colored classes were obtained, buff (plate 1, fig. 7) and testaceous, like the Red Kidney (plate 1, fig. 1). Since other red colors will be encountered later, this shade of red will be known as testaceous. This gene pair is represented by $R k$ (buff) $r k$ (testaceous). The $\mathrm{F}_{2}$ should segregate for three genes : $M, R k$, and $B l$. Since the red parent contributed $B l$ the buff phenotypes may be $P m R k B l$ or $P m R k b l$ and the testaceous, $P m r k B l$ or $P m r k b l$. In other words, the presence of $B l$ cannot be distinguished in the self-colored segregates. In the mottled beans four classes can be distinguished as follows : $P M R k B l$ purple/buff, $P M r k B l$ purple/testaceous, $P M$ $R k b l \mathrm{red} / \mathrm{buff}$, and $P M r k b l \mathrm{red} / \mathrm{testaceous.} \mathrm{Thus,} \mathrm{the} R k$ gene can be distinguished in both mottled and self-colored beans, $m R k$ being buff self-colored, $M R k$ mottled on buff background, $m r k$ testaceous selfcolored, and $M r k$ mottled on testaceous background. The $B l b l$ pair can be distinguished only in the mottled types, $M B l$ being purple-mottled and $M b l$ red-mottled. The expected ratio in $\mathrm{F}_{2}$ should be $27 P M R k B l$ purple/buff : $9 P M r k B l$ purple/testaceous : $9 P M R k b l$ red/buff : 3 $P M r k b l$ red/testaceous: $12 P m R k$ buff : $4 P m r k$ testaceous. $\mathrm{F}_{3}$ progeny tests were made of a few $\mathrm{F}_{2}$ phenotypes. The results of $\mathrm{F}_{2}$ and $\mathrm{F}_{3}$ from this cross are presented in table 1 .

If the assumptions in respect to the genotypes are correct, the purple/ buff ( $P M R k B l$ ) should segregate for all three, any two, any one, or none of the genes $M, R k, B l$. In the progenies tested one segregated for $M, R k, B l$; one for $M, B l$; one for $M R k$; and one for $B l$.

The purple/testaceous ( $P M r k B l$ ) should segregate for either one or both of the genes $M$ and $B l$. No purple/buff, red/buff, or buff segregates are expected because all $\mathrm{F}_{2}$ beans of this phenotype are homozygous for $r k$. Only one progeny test was made. It segregated for $M$ and $B l$. The red/buff ( $P M R k b l$ ) should segregate for only two genes at most, $M$ and $R k$. No purple mottled are expected in any of the progeny because they all carry $b l$. One of those tested segregated for $M$ and $R k$ and another bred true. The buff phenotype ( $P m R k$ ) should segregate for $R k$ or breed true. Four progeny tests were made; three segregated for $R k$, the other bred true. The testaceous phenotypes $(P m r k)$ should all breed true, and four progeny tests made of this phenotype did so.

\section{SPECKLED KIDNEY $\times$ RED KIDNEY}

(Formula: $P M R k b l \times P m r k B l$ )

The maternal parent of this cross (plate 1 , fig. 5 ) is red/buff. The $F_{1}$ was purple/buff (plate 1, fig. 9). The $\mathrm{F}_{2}$ should segregate $27 P M R k B l$ purple/buff : $9 P M r k B l$ purple/testaceous : $9 P M R k b l$ red/buff : 3 
[Vol. 12, No. 9

\begin{tabular}{|c|c|c|c|c|c|c|c|c|c|c|c|c|c|c|c|}
\hline & & 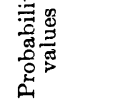 & & $\stackrel{7}{\circ}$ & & $\begin{array}{l}\overline{0} \\
\dot{0}\end{array}$ & $\stackrel{8}{\circ}$ & $\begin{array}{l}\stackrel{8}{\infty} \\
\stackrel{0}{0}\end{array}$ & $\stackrel{\circ}{\circ}$ & $\begin{array}{l}\infty \\
\infty \\
0\end{array}$ & $\begin{array}{l}1 \\
\infty \\
0 \\
0\end{array}$ & & $\begin{array}{l}\text { 尺े } \\
\text { Oे }\end{array}$ & & $\vdots$ \\
\hline & & $\begin{array}{l}\text { 吾 } \\
0 \\
0\end{array}$ & & 念 & & $\varrho$ & $\stackrel{9}{\longrightarrow}$ & $\simeq$ & $\infty$ & $\because 2$ & $=$ & os & $\vec{N}$ & 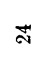 & 128 \\
\hline & & 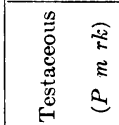 & & 은 & & 0 & : & : & 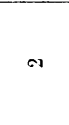 & + & : & : & 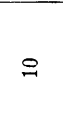 & : & 's \\
\hline & & 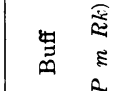 &. & లో & $\stackrel{5}{g}$ & $\infty$ & $\sim$ & & 0 & : & $\sim$ & : & tే & $\mathbb{N}$ & \\
\hline & 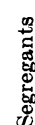 & 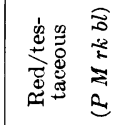 & 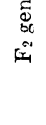 & $\cong$ & 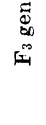 & $\sigma$ & : & $:$ & : & + & : & : & : & $:$ & \\
\hline 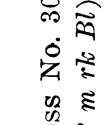 & & 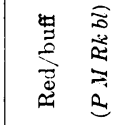 & & 유 & & $\because$ & - & + & - & : & $\sigma$ & 0 & : & : & : \\
\hline 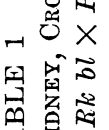 & & 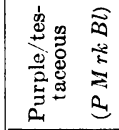 & & ๓ & & - & : & : & : & $1-$ & : & : & : & $:$ & : \\
\hline 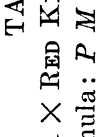 & & 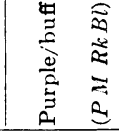 & & $F$ & & $\infty$ & $\stackrel{\oplus}{\circ}$ & $\infty$ & סה & : & : & : & : & : & : \\
\hline 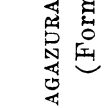 & & 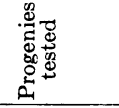 & & $\sigma$ & & $\rightarrow$ & -1 & - & - & - & -1 & - & $\infty$ & - & $\pi$ \\
\hline & & 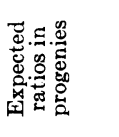 & & 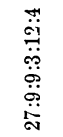 & & 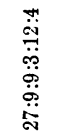 & 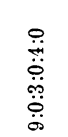 & 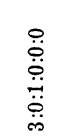 & $\begin{array}{l}\overrightarrow{\ddot{o}} \\
\ddot{\phi} \\
\dot{\varphi} \\
\dot{\phi}\end{array}$ & 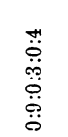 & $\begin{array}{l}\stackrel{0}{\ddot{0}} \\
\stackrel{\ddot{0}}{0} \\
\ddot{0}\end{array}$ & $\begin{array}{l}\overline{7} \\
\stackrel{\sigma}{0} \\
\stackrel{0}{0}\end{array}$ & $\begin{array}{l}\ddot{\ddot{o}} \\
\ddot{0} \\
\ddot{0} \\
\ddot{0}\end{array}$ & 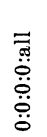 & 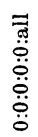 \\
\hline & & 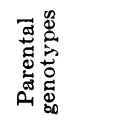 & 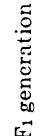 & 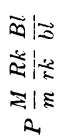 & 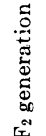 & 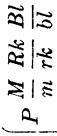 & 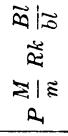 & 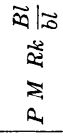 & 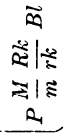 & 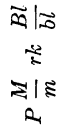 & 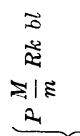 & $\begin{array}{l}\overrightarrow{0} \\
\overrightarrow{0} \\
= \\
0\end{array}$ & 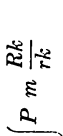 & 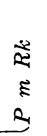 & $\begin{array}{l}3 \\
3 \\
\vdots \\
2\end{array}$ \\
\hline & & 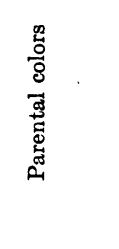 & & 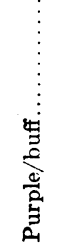 & & & 8 & & & 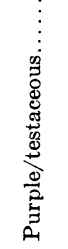 & 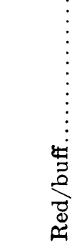 & & $\infty$ & & 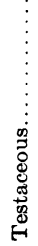 \\
\hline
\end{tabular}


$P M r k b l$ red/testaceous : $12 P m R k$ buff : $4 P m r k$ testaceous, as did the last cross. Results are shown in table 2 . The $\mathrm{F}_{2}$ with 275 plants gave a probability value of 0.05 fitted to such a ratio. In $\mathrm{F}_{3}$ the same results should be expected as reported in table 1 . Five purple/buff $\mathrm{F}_{3}$ progenies segregated for $M, R k$, and $B l$; one for $M$ and $R k$; three for $M$ and $B l$; three for $R k$ and $B l$; and three for $R k$. The purple/testaceous had one progeny segregating for $M$ and $B l$; two for $M$; and three for $B l$. Two bred true. Three red/buff segregated for $M$ and $R k$, one for $R k$, and two bred true. Four red/testaceous progenies segregated for $M$. In one of these progenies, there unexpectedly appeared two purple/testaceous plants ; these were probably due to natural hybridization with a purplemottled bean. Three red/testaceous $\mathrm{F}_{2}$ plants bred true in $\mathrm{F}_{3}$. Five progenies from buff segregated for $R k$ and six bred true. Eight testaceous progenies bred true as expected.

\section{RED KIDNEY $\times$ LONG ROMAN}

(Formula: $P m r k B l \times P M R k b l$ )

There are two crosses grouped together in table 3. Long Roman (plate 1 , fig. 3) is red/buff. The $F_{1}$ was purple/buff, so similar results are expected in these crosses as in the preceding ones. The probability value for $\chi^{2}$ is very small. For this reason the calculated numbers are here given for each color group. The major discrepancy is the low number of purple/testaceous plants and the high number of red/testaceous. The self-colored testaceous class is also low. Is this discrepancy due to some disturbing genetic conditions or could it be due to errors in classification? The three segregating genes are $M, R k$, and $B l$. There were 256 mottled $(M)$ and 78 self-colored $(m)$. This fits a $3: 1$ ratio with a probability value of 0.49 . The total number of beans with $R k$ were 262 and with $r k, 72$. This fits a $3: 1$ ratio with a probability value of 0.16 . Only mottled beans show reaction for the $B l$ gene. There were $168 \mathrm{Bl}$ and 88 $b l$. For a $3: 1$ ratio, $192: 64$ is expected. The probability value is 0.05 . Thus it appears that each gene taken separately fits the expected ratios fairly well.

Linkage between $M$ and $B l$ cannot be measured because $B l$ is not apparent in self-colored $(m)$ beans. Segregation for $M$ and $R k$ was : 196 $M R k, 60 M r k, 66 m R k$, and $12 m r k$. Fitted to a $9: 3: 3: 1$ ratio the expected numbers are $187.87: 62.63: 62.63: 20.87$, respectively, with a probability value of 0.22 , indicating no linkage. Segregation for $R k$ and $B l$ can be studied only in the mottled beans. The segregation of $R k$ and $B l$ was : $144 R k B l, 52 R k b l, 24 r k B l$, and $36 r k b l$. For a $9: 3: 3: 1$ ratio the calculated numbers for these classes are 144: 48: $48: 16$. Thus the 
[Vol. 12, No. 9

\begin{tabular}{|c|c|c|c|c|c|c|c|c|c|c|c|c|}
\hline & & 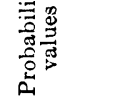 & & 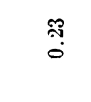 & $\stackrel{m}{0}$ & '̊: & & $\vec{Z}$ & $\stackrel{\infty}{\dddot{\oplus}}$ & $\stackrel{\infty}{\dddot{g}}$ & 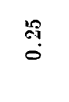 & $\begin{array}{l}\mathscr{0} \\
0\end{array}$ \\
\hline & & $\begin{array}{l}\bar{J} \\
\stackrel{5}{0}\end{array}$ & & : & $\stackrel{\infty}{g}$ & $\stackrel{18}{\mathrm{i}}$ & & 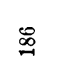 & $\ddot{\infty}$ & $\stackrel{乛}{9}$ & ఫ్తి & $\vec{\infty}$ \\
\hline & & 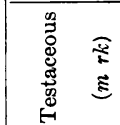 & & מת & $\cong$ & $\stackrel{\mathscr{A}}{\sim}$ & & $\stackrel{2}{2}$ & $\rightarrow$ & : & : & : \\
\hline & & 焗 & & $\mathcal{ส ~}$ & $\hat{\text { mे }}$ & 品 & & జి & $\infty$ & $\stackrel{\infty}{\sim}$ & : & : \\
\hline 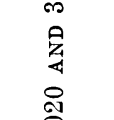 & 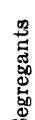 & 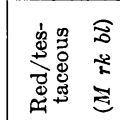 & 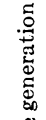 & - & 0 & $n$ & 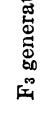 & $=$ & : & . & $\infty$ & : \\
\hline 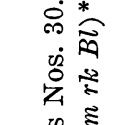 & & 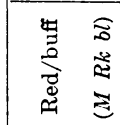 & & $\exists$ & ले & $\stackrel{\infty}{\not \rightarrow}$ & & $\ddot{\infty}$ & : & $\ddot{\varnothing}$ & $\stackrel{4}{*}$ & : \\
\hline 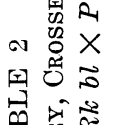 & & 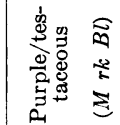 & & $=$ & $\approx$ & $\stackrel{\sim}{\infty}$ & & สี & 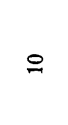 & : & ఇ๊ & ఇ \\
\hline 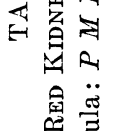 & & 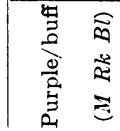 & & $\tilde{N}$ & $\infty$ & $\stackrel{20}{=}$ & & $\stackrel{\infty}{\sim}$ & $\stackrel{\oplus}{\circ}$ & $\approx$ & 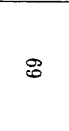 & $\vec{\sigma}$ \\
\hline 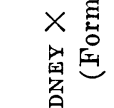 & & 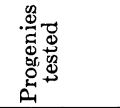 & & $\rightarrow$ & $\pi$ & مו & & is & - & $\infty$ & $\infty$ & $\infty$ \\
\hline 触 & & 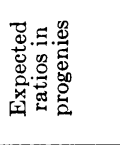 & & 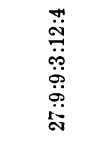 & 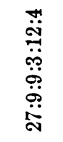 & 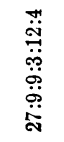 & & 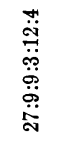 & $\begin{array}{l}\ddot{\ddot{o}} \\
\stackrel{0}{0} \\
\ddot{\varphi} \\
\ddot{o}\end{array}$ & $\begin{array}{l}\stackrel{0}{\ddot{0}} \\
\stackrel{\ddot{\varphi}}{0} \\
\ddot{0}\end{array}$ & 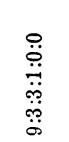 & \\
\hline & & 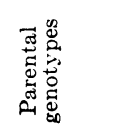 & 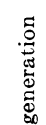 & 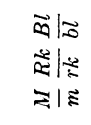 & 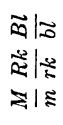 & 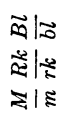 & 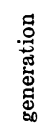 & 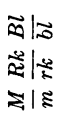 & $\begin{array}{l}\vec{\infty} \\
\vec{a} \mid: \\
\Sigma \mid \Xi\end{array}$ & 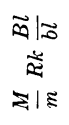 & $\begin{array}{l}\overrightarrow{0} \mid \overrightarrow{0} \\
\overrightarrow{2} \mid: \\
=\end{array}$ & $\begin{array}{l}\overrightarrow{0} \\
\vec{z} \mid= \\
z\end{array}$ \\
\hline & & 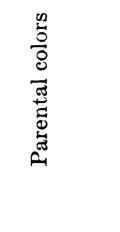 & & 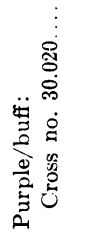 & 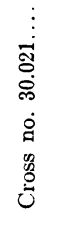 & 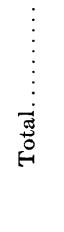 & & & & 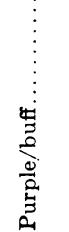 & & \\
\hline
\end{tabular}




\begin{tabular}{|c|c|c|c|c|c|c|c|c|c|c|c|c|c|}
\hline 兑 & $\begin{array}{l}8 \\
0 \\
0\end{array}$ & 思 & $\vdots$ & $\begin{array}{l}\vec{t} \\
0\end{array}$ & P & ஸీ & $\vdots$ & 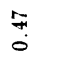 & $\vdots$ & $\vdots$ & 苛 & $\vdots$ & $\vdots$ \\
\hline$\stackrel{\infty}{\sim}$ & $\infty$ & $\stackrel{0}{1}$ & $\overrightarrow{6}$ & $\exists$ & $\stackrel{\Re}{\dddot{q}}$ & ন & $F$ & 2ㅗㅇ & $\stackrel{\infty}{\sim}$ & 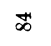 & 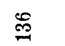 & $\vec{\infty}$ & ஜ్ఞ \\
\hline$\infty$ & 로 & : & : & مa & : & : & : & $\Re$ & $\nabla$ & : & 요 & : & ஜึ๊ \\
\hline : & : & : & : & คి & : & $\theta$ & : & : & : & : & $\mathscr{Z}$ & $\underset{\infty}{=}$ & : \\
\hline$N$ & : & శి & : & 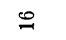 & $\mathscr{A}$ & : & : & ๙ & $\stackrel{\sim}{-1}$ & 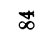 & : & : & : \\
\hline : & : & : & : & " & ப' & 尺ి & $F$ & : & : & : & : & : & : \\
\hline$\cong$ & $\stackrel{F}{*}$ & 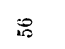 & $\overrightarrow{0}$ & : & : & : & : & : & \pm & : & : & : & : \\
\hline & : & : & : & : & : & : & : & : & : & : & : & : & : \\
\hline- & $\infty$ & $\infty$ & ค & $\infty$ & مמ & - & $N$ & $\infty$ & $\rightarrow$ & $\infty$ & م20 & 0 & $\infty$ \\
\hline 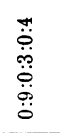 & $\begin{array}{l}\ddot{0} \\
\ddot{0} \\
\ddot{0} \\
\ddot{0}\end{array}$ & 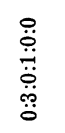 & ": & $\begin{array}{l}\ddot{\ddot{\varphi}} \\
\ddot{\leftrightarrow} \\
\ddot{\phi} \\
\ddot{0}\end{array}$ & & 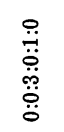 & 蕓 & 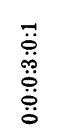 & 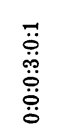 & & 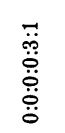 & 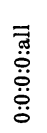 & 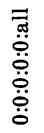 \\
\hline$\tilde{\Delta}: \vec{s}$ & $\vec{\infty}$ & $\vec{\infty} \mid \approx$ & $\overrightarrow{0}$ & $\approx$ & $\approx$ & $\approx$ & $\approx$ & $\overrightarrow{0}$ & $\approx$ & $\approx$ & & & \\
\hline$\doteqdot$ & $\dot{\Xi}$ & $\dddot{\sharp}$ & $\dddot{2}$ & 齐|: & 岕|心 & एँّ & $\dot{2}$ & $\$$ & $\rightleftarrows$ & 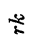 & 䓛| & स्ट & $\rightleftarrows$ \\
\hline 71 . & $\sum 1 E$ & $\beth$ & $\mathcal{Z}$ & $\sum$ & $\Sigma$ & $\Sigma 1 E$ & $z$ & $\underline{Z I E}$ & $\underbrace{215}$ & $\Sigma$ & $\underbrace{E}$ & $\leftleftarrows$ & $\xi$ \\
\hline & 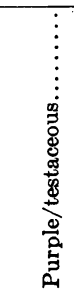 & & & & 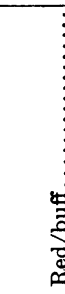 & & & & 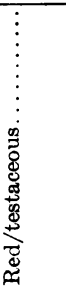 & & 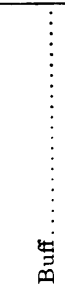 & & 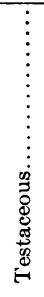 \\
\hline
\end{tabular}




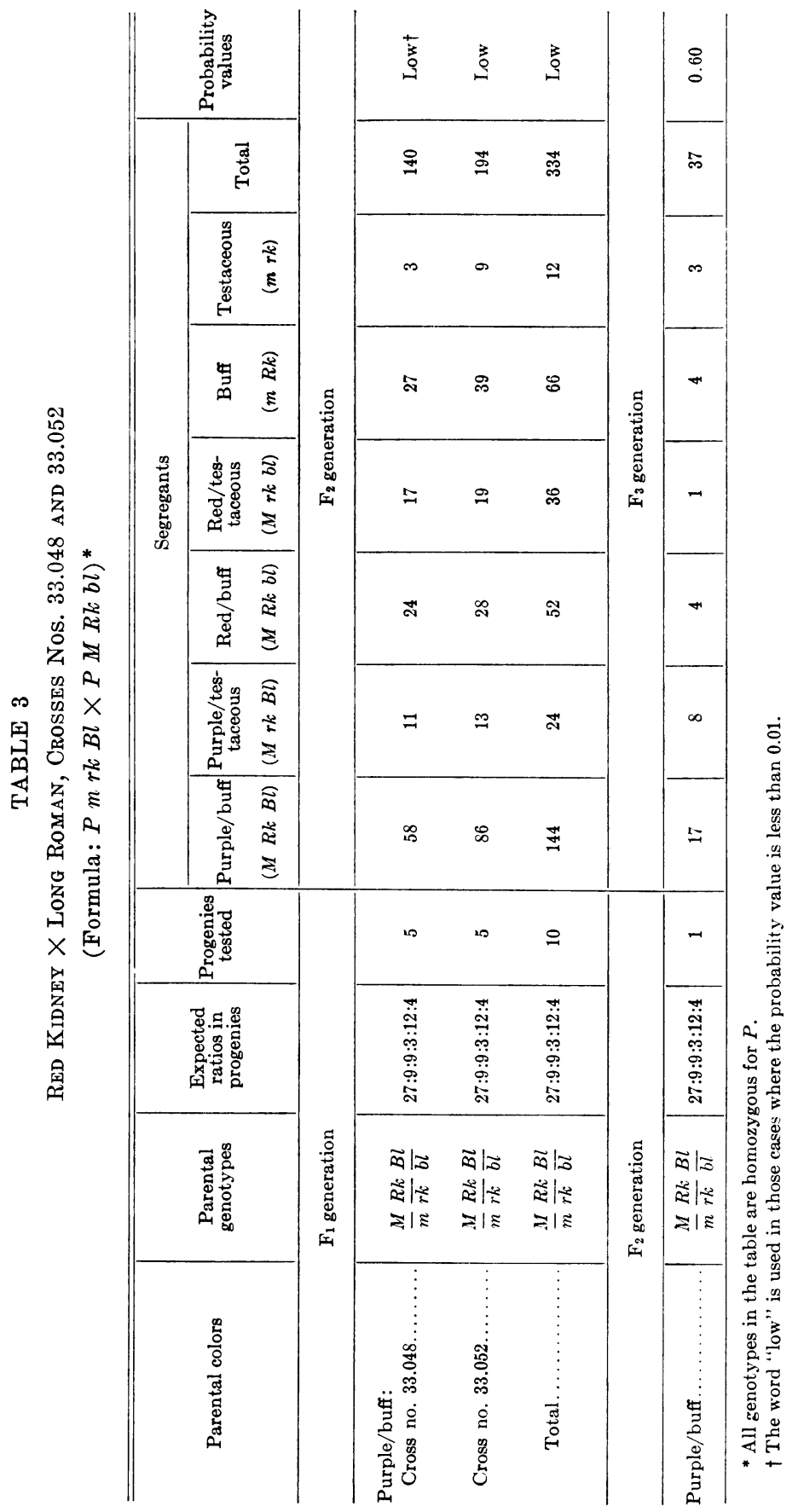


purple/testaceous $(r k B l)$ class is too small and the red/testaceous ( $r k$ $b l$ ) class is too large for a good fit. The probability value is very low when these data are fitted to such a ratio. Since the $R k$ gene came from one parent, and the $B l$ from the other, the double recessive class $r k b l$ should be low if linkage were the cause of the poor fit. As a matter of fact the reason for the poor fit is that this class is too large, which leaves no explanation for the discrepancy except a failure to accurately distinguish between purple/testaceous and red/testaceous color classes.

A single $\mathrm{F}_{2}$ purple/buff was tested in $\mathrm{F}_{3}$. Fitted to the expected ratio for three independently segregating genes these data showed no discrepancy as observed in the $\mathrm{F}_{2}$, the probability value being 0.60 .

\section{RED EYE $\times$ RED KIDNEY}

(Formula: $P$ e $r k \times P E r k$ )

Red Kidney is testaceous self-colored (plate 1, fig. 1); Red Eye is a white kidney bean with a red eye pattern like Lamprecht's (13) "virgarcus" (plate 1, figs. 34, 35).

Now if the red color is genetically the same in both varieties, we should expect a monohybrid segregation for eye pattern, $e$. The $\mathrm{F}_{1}$ was testaceous self-colored. The $\mathrm{F}_{2}$ and $\mathrm{F}_{3}$ ratios are shown in table 4 . The probability value for $\mathrm{F}_{2}$ data fitted to a $3: 1$ ratio was 0.33 and for nine segregating families in $\mathrm{F}_{3}$ it was 0.84 . Twelve $\mathrm{F}_{3}$ families from testaceous $\mathrm{F}_{2}$ were tested; 9 segregated testaceous eye and 3 bred true. The probability value is 0.55 when these data are fitted to the expected $2: 1$ ratio.

The red color in Red Eye is therefore genetically the same as in Red Kidney. These varieties differ only in the gene $e$ for eye pattern. As pointed out by Lamprecht (13) this type of pattern may in fact be due to a dominant Bip ("virgarcus") gene, the recessive bip (bipunctata) not being present. The genotype for Red Kidney then is $P E B$ Bip rk and for Red Eye $P$ e Bip $r k$.

\section{BUFF $\times$ RED EYE, AND RECIPROCAI}

(Formulas: $P E R k \times P e r k$ and $P$ erk $\times P E R k$ )

The buff beans used in these reciprocal crosses were true-breeding $\mathrm{F}_{3}$ extracts from the cross reported in table 1 and were therefore of the genetic constitution $P m R k$. If the assumptions are true for the cross reported in table 4 , the results can be predicted for these. The $\mathrm{F}_{1}$ should be buff self-colored and the $\mathrm{F}_{2}$ should segregate into $9 P E R k$ buff selfcolored : $3 P e R k$ buff eye : $3 P E r k$ testaceous self-colored: $1 P e r k$ testaceous eye. The results are shown in table 5 . They are in conformity with expectations. These results prove that the red (testaceous) found 
[Vol. 12, No. 9

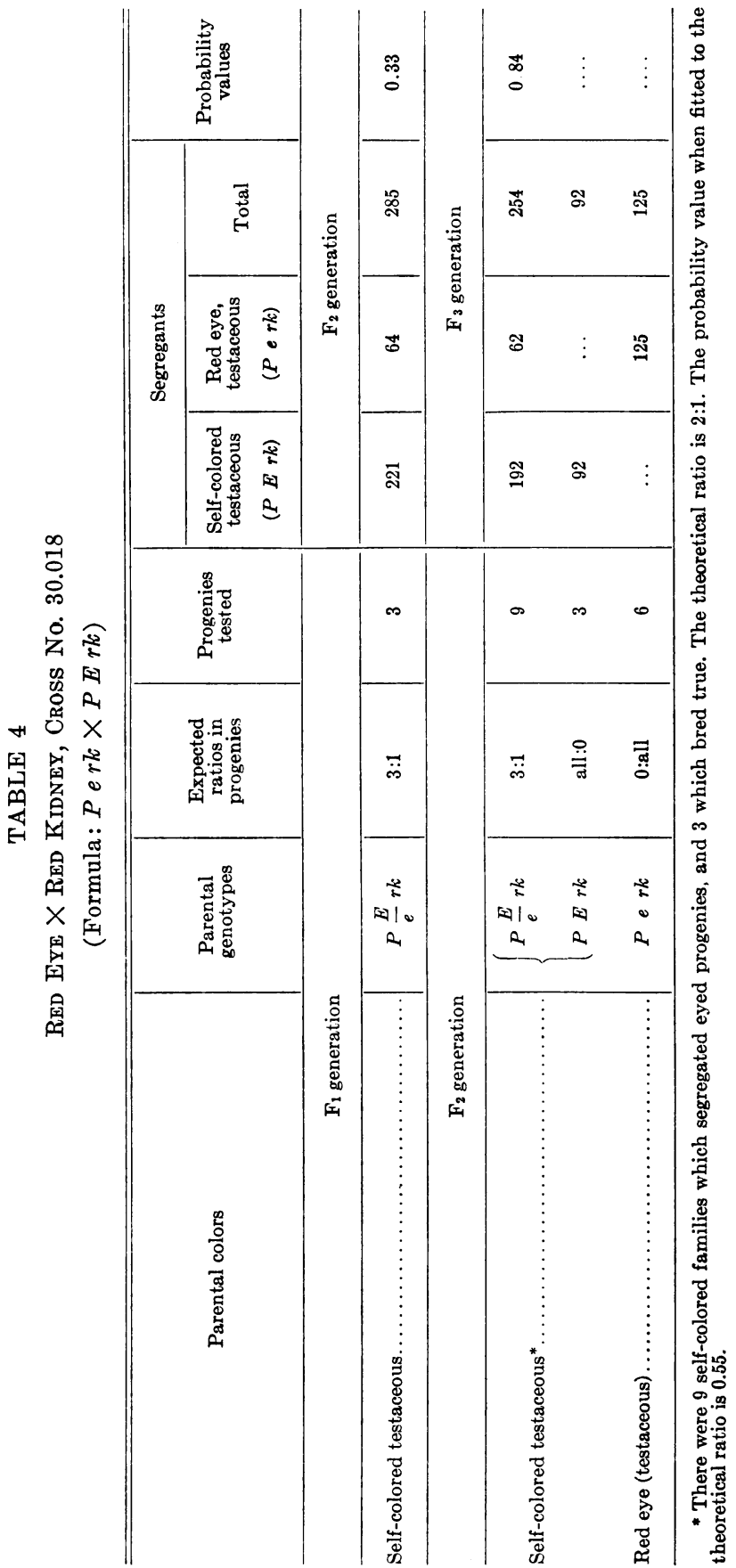




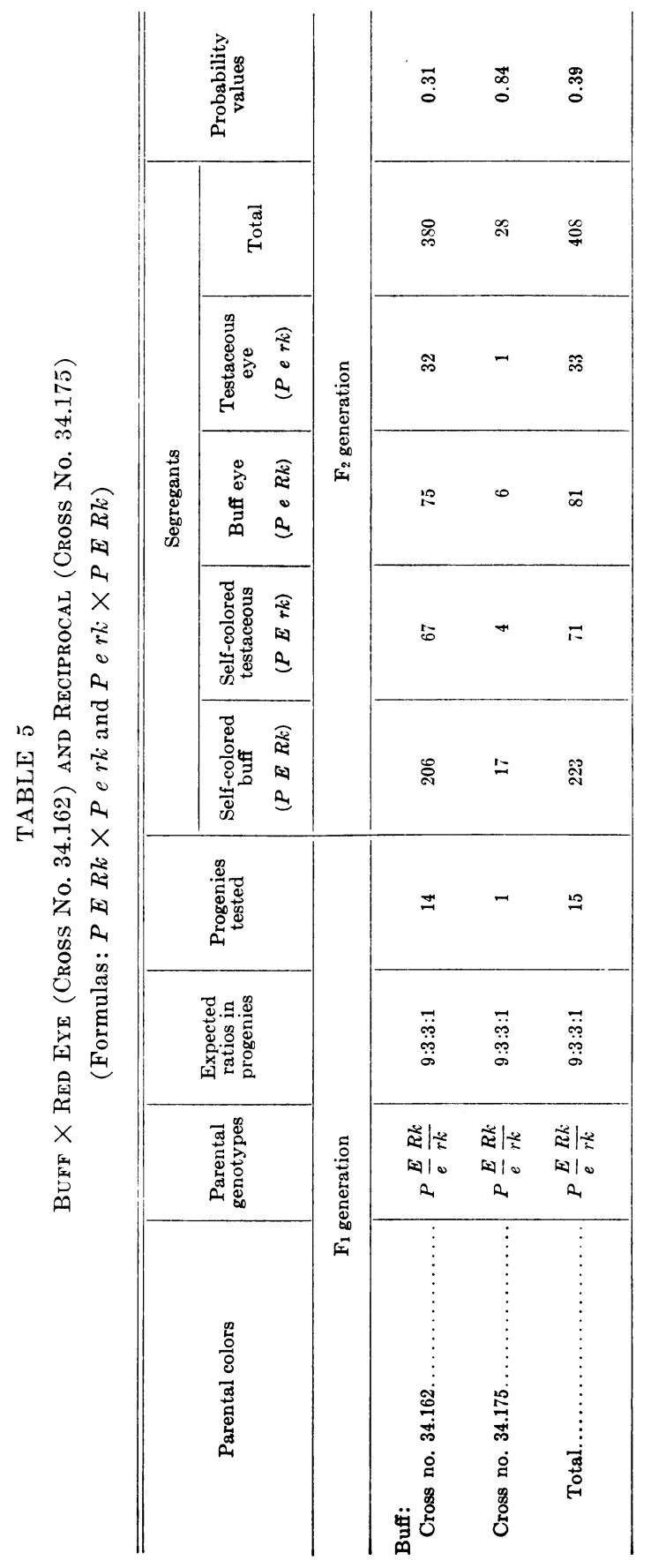


[VoL. 12 , No. 9

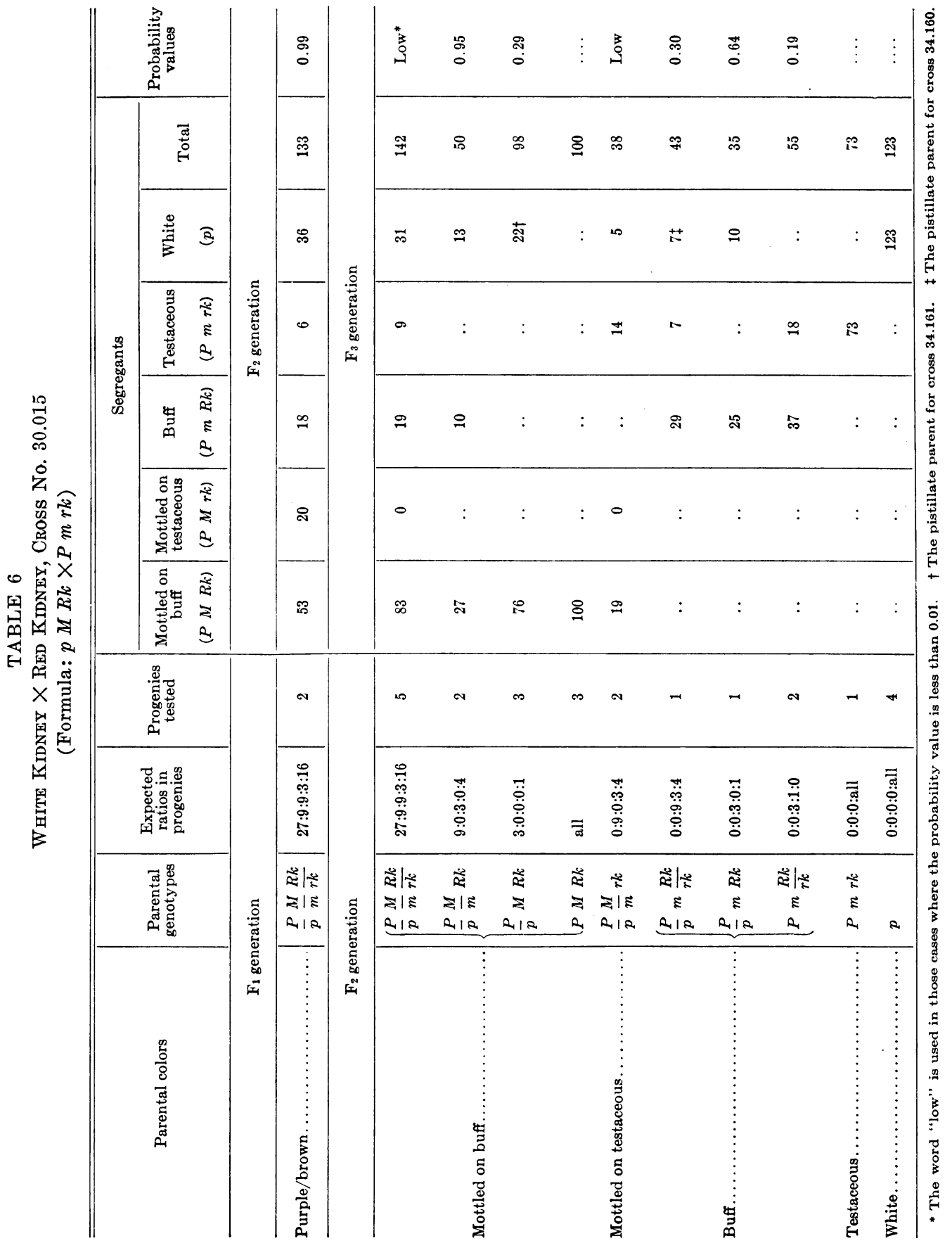


in Red Kidney is due to the expression of a recessive gene, the dominant allelomorph being buff, which is represented by the symbol $R k$ (buff) $r k$ (testaceous). A recessive gene $e$ is responsible for eye pattern demonstrated first by Emerson (3). Its dominant allelomorph, $E$ makes beans self-colored. There is no indication of linkage between $R k$ and $E$.

\section{WHITE KIDNEY $\times$ RED KIDNEY}

(Formula: $p M R k \times P m r k$ )

The $F_{1}$ in this cross was mottled purple/buff. The white parent therefore carried $M$ and $R k$ and one of the two parents carried $B l$; it is impossible to know which, because the $B l$ reaction is not evident in either testaceous or white beans. In $\mathrm{F}_{2}$ there were a number of purple-mottled types ranging from bluish to dark red. These colors were not described accurately enough in the author's original notes to enable one to follow the segregation of $B l$ or its modifiers. The genes segregating in this cross were $P, M$, and $R k$. The results are shown in table 6 . Since all genotypes homozygous for $p$ are white, the $M$ and $R k$ genes can only be followed in three-fourths of the population. The expected ratio for this cross is 27 $P M R k$ mottled on buff : $9 P M r k$ mottled on testaceous : $9 P m R k$ buff : $3 P m r k$ testaceous : $16 p$ white. In an $\mathrm{F}_{2}$ population of 133 , a probability value of 0.99 was obtained, when fitted to this ratio. In $\mathrm{F}_{3}$, five progenies from mottled on buff were segregating for $P, M$, and $R k$. No mottled-on-testaceous beans were found in a population of 142 although there were 9 self-colored testaceous. The absence of this mottled class made a very poor fit for the expected ratio. Perhaps some mottled-ontestaceous beans were misclassified. Two $\mathrm{F}_{2}$ mottled-on-buff types segregated for $P$ and $M$. Three segregated for $P$ and three bred true.

Only two mottled-on-testaceous $\mathrm{F}_{2}$ plants were submitted to progeny tests. Both segregated for $P$ and $M$. The results here are spurious because the mottled offspring were all expected to be mottled on testaceous. There were none of this class but there were 19 mottled on buff which were not expected. This discrepancy may have been due to misclassification of the $\mathrm{F}_{2}$ plant. The buff $\mathrm{F}_{2}$ plants could segregate for $P$ and $R k$ or breed true. Four were tested in $\mathrm{F}_{3}$. One segregated for $P$ and $R k$; one for $P$; and one for $R k$. One testaceous $\mathrm{F}_{2}$ plant and four whites bred true in $\mathrm{F}_{3}$.

The results of this cross show segregation for $P, M$, and $R k$. In $\mathrm{F}_{3}$ progeny tests, the number of plants mottled on testaceous background ( $P M$ $r k$ ) was usually low. This low number may have been due to misclassification but it is possible that the presence of modifiers altered the segregation of $P M r k$ types. 


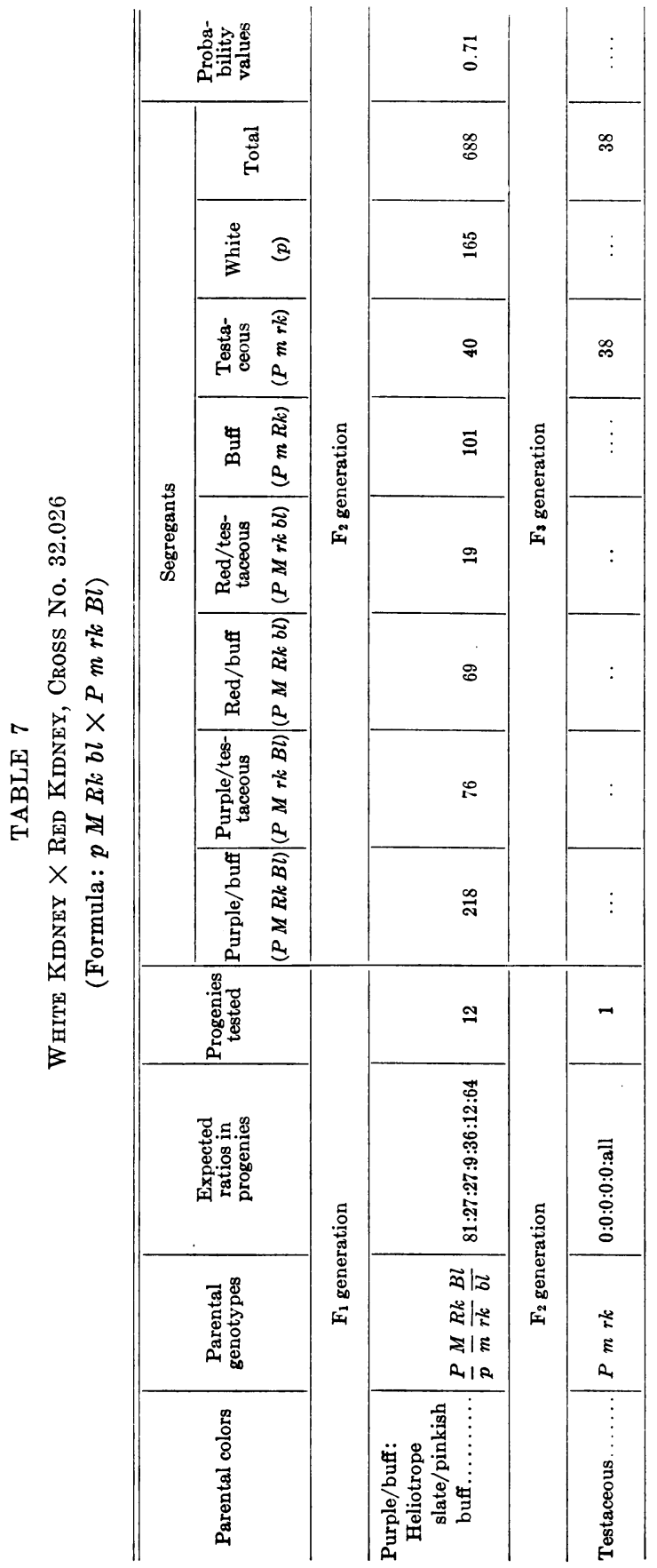




\section{WHITE KIDNEY $\times$ RED KIDNEY}

(Formula: $P M R k b l \times P m r k B l$ )

This cross is the same as the one just discussed; the colors in the $\mathrm{F}_{2}$ were more carefully classified so the segregation of $B l$ could be followed. Table 7 gives a summary of the results. This summary, however, fails to show all the variability encountered. Some phenotype classes contain several colors. The purple/buff class had 54 dark Yvette violet/pinkish buff, 56 Urania blue/pinkish buff, and 108 Ramier blue/pinkish buff, making a total of 218 plants. The purple/testaceous class consisting of 76 plants included 52 analine black/testaceous and 24 dark Corinthian purple/ocher red. The red/buff class had 69 plants which were divided into 19 dark vinaceous-purple/pinkish buff and 50 vinaceous-purple/ pinkish buff. The color names indicate that these beans were purple. They showed a slight tinge of purple but were predominantly red. The other colored classes were more uniform, all the red/testaceous were classified as oxblood red/testaceous, all the buff as light pinkish cinnamon, all testaceous as testaceous, and white as white.

There were no $\mathrm{F}_{3}$ progeny tests made in this cross so it is not possible to say whether the classification made was absolutely correct. Four independent genes were segregated, namely, $P, M, R k$, and $B l$.

\section{GLOYER'S CROSS, WHITE KIDNEY $\times$ RED KIDNEY}

(Formulas: $p C R k \times p c r k$ and $P c r k \times p C R k$ )

In 1928, Gloyer (5) reported on a cross between these two varieties. Inasmuch as the $R k$ gene was encountered, his results are given in table 8. He made no attempt to classify the genotypes, so this has been done from his data. The $F_{1}$ was mottled brown/buff; it might be supposed, therefore, that White Kidney contributed $M$ and $R k$. In the $\mathrm{F}_{2}$, however, the segregation was 103 mottled: 102 self-colored: 56 white. This is much nearer a $6: 6: 4$ ratio than to a $9: 3: 4$. The mottling, then, was due to a heterozygous gene like Lamprecht's $C$. The $\mathrm{F}_{1}$ was brown/buff; and, since brown/buff, brown/red, buff, red, and white were obtained in $\mathrm{F}_{2}$, this cross obviously segregated for $R k$ as well as for $P$ and $C$. In the $\mathrm{F}_{2}$ a number of brown segregates were found-bronze, brown, dark brown, and seal brown. In $\mathrm{F}_{3}$ there was no consistency in the way these brown beans segregated. Bronze, for instance, segregated into bronze, brown, and seal brown, but so did seal brown. For purposes of classification the browns may be grouped together. This classification undoubtedly oversimplifies the situation as will appear later. The browns may be considered to be homozygous for $C$. They may be either $P C R k$ or $P C r k$. The 


\begin{tabular}{|c|c|c|c|c|c|c|c|c|c|c|c|c|}
\hline & 苞 & 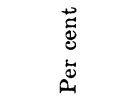 & & & & $\stackrel{\oplus}{-}$ & & $\stackrel{\circ}{-}$ & $\dddot{0}$ & & $\vdots$ & $\vdots$ \\
\hline & 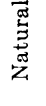 & $\frac{\dot{\Phi}}{\stackrel{\Xi}{\Xi}}$ & & : & & N & : & $\stackrel{2}{2}$ & $r$ & : & : & : \\
\hline & & 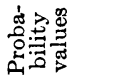 & & $\begin{array}{l}\stackrel{0}{\circ} \\
\stackrel{0}{0}\end{array}$ & & $\stackrel{8}{8}$ & $\stackrel{9}{0}$ & 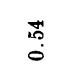 & $\begin{array}{l}\overrightarrow{0} \\
\dot{0}\end{array}$ & $\begin{array}{l}\mathscr{8} \\
\stackrel{0}{0}\end{array}$ & $\begin{array}{l}\infty \\
\stackrel{0}{0} \\
0\end{array}$ & 官 \\
\hline $\begin{array}{l}\overrightarrow{4} \\
\text { J }\end{array}$ & & 莨 & & $\overrightarrow{\mathrm{s}}$ & & $\mathbb{I}$ & Fi & \& & 菬 & $\mathscr{F}$ & 疍 & \& \\
\hline 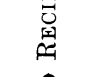 & & $\stackrel{\stackrel{ \pm}{3}}{\Xi}$ & & in & & q & 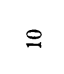 & : & : & : & \% & : \\
\hline 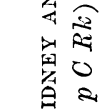 & & 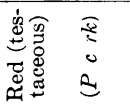 & 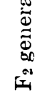 & $\stackrel{\infty}{\sim}$ & 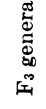 & $\infty$ & & tr & & : & $\mathscr{\infty}$ & $\stackrel{0}{\circ}$ \\
\hline 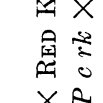 & 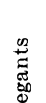 & 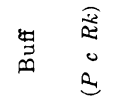 & & ஓి & & 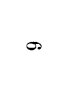 & 10 & $\approx$ & $\overleftrightarrow{N}$ & $\cong$ & : & $:$ \\
\hline 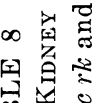 & $\begin{array}{l}\infty \\
\text { के }\end{array}$ & 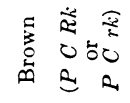 & & : & & 尺: & $\infty$ & 18 & iี & $\infty$ & $\mathscr{\wp}$ & $\approx$ \\
\hline 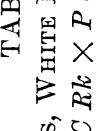 & & 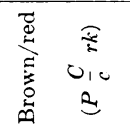 & & $\dot{m}$ & & \pm & : & $\infty$ & : & : & مَ' & ๙্ \\
\hline 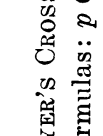 & & 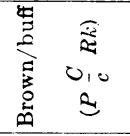 & & 8 & & $\stackrel{8}{R}$ & : & 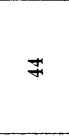 & is & ส & : & $:$ \\
\hline 葛焉 & & 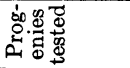 & & $\sigma$ & & + & r & $\sigma$ & 0 & - & 0 & $\infty$ \\
\hline 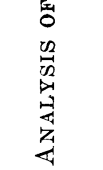 & & 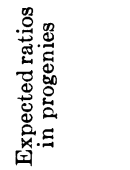 & & 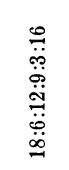 & & 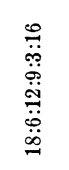 & $\begin{array}{l}\stackrel{\pi}{0} \\
\stackrel{0}{0} \\
\ddot{0} \\
\dot{0}\end{array}$ & 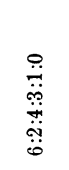 & 芦 & 兑 & 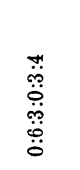 & 芦 \\
\hline & & 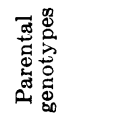 & 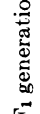 & $\begin{array}{l}\text { 焉|: } \\
010 \\
0112\end{array}$ & 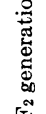 & $\begin{array}{l}\text { 焉1: } \\
010 \\
218\end{array}$ & $\begin{array}{l}\text { एक } \\
010 \\
218\end{array}$ & 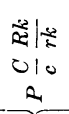 & $\begin{array}{l}0 \\
010 \\
0\end{array}$ & $\begin{array}{c}* \\
010 \\
010 \\
2 \\
\end{array}$ & $\begin{array}{l}2 \\
010 \\
212\end{array}$ & $\begin{array}{c}2 \\
010 \\
2\end{array}$ \\
\hline & & 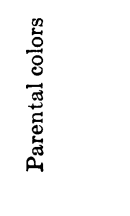 & & 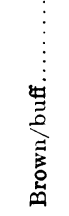 & & & & 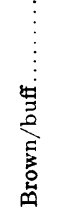 & & & 总 & \\
\hline
\end{tabular}




\begin{tabular}{|c|c|c|c|c|c|c|c|c|c|c|c|c|c|}
\hline$\vdots$ & $\stackrel{0}{-}$ & $\vec{\sigma}$ & $\stackrel{0}{-}$ & $\vdots$ & $\vec{i}$ & $\stackrel{\sim}{+}$ & $\dot{0}$ & $\begin{array}{l}\infty \\
\text { ai }\end{array}$ & $\ddot{m}$ & $\vdots$ & $\vdots$ & $\stackrel{0}{\circ}$ & \\
\hline : & -1 & N & - & : & N & - & $\infty$ & - & $\infty$ & : & $:$ & $\infty$ & \\
\hline$\stackrel{5}{\mathfrak{n}}$ & $\vdots$ & $\vdots$ & $\stackrel{\$}{\infty}$ & $\vdots$ & $\vdots$ & 薄 & 㞧 & $\stackrel{\mathscr{T}}{0}$ & $\vdots$ & $\stackrel{\infty}{0}$ & $\vdots$ & $\vdots$ & \\
\hline "̈ & ชั & สี & $\Xi$ & 识 & in & $\vec{N}$ & to & $\mathscr{్}$ & జు & $\stackrel{\varnothing}{\circ}$ & $t$ & $\vec{S}$ & \\
\hline 음 & $:$ & : & ల్ల & 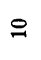 & : & - & : & $:$ & $:$ & $\cong$ & $:$ & $\vec{\Phi}$ & 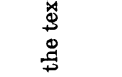 \\
\hline : & $\infty$ & : & : & - & : & $\Rightarrow$ & $=$ & - & : & $\Re$ & $\widehat{Ð}$ & : & 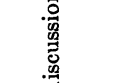 \\
\hline : & $\stackrel{\sim}{\sim}$ & : & : & $\infty$ & : & $\cong$ & 용 & $\stackrel{乛}{~}$ & 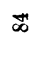 & : & : & : & \\
\hline$\vec{N}$ & $\mathscr{H}$ & ส & $\mathscr{\sigma}$ & $\bar{F}$ & in & : & : & : & : & : & : & : & \\
\hline : & : & : & : & : & $:$ & : & : & : & : & : & : & : & 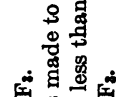 \\
\hline : & : & : & : & : & : & : & : & : & : & : & : & : & 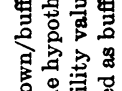 \\
\hline N & N & a & סמ & - & $\rightarrow$ & - & $\sim$ & - & $\infty$ & - & N & $\cong$ & 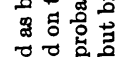 \\
\hline $\begin{array}{l}\ddot{0} \\
\ddot{0} \\
\ddot{g} \\
\ddot{0}\end{array}$ & $\begin{array}{c}\vdots \\
\vdots \\
\vdots\end{array}$ & 苛 & $\begin{array}{l}\ddot{\ddot{o}} \\
\ddot{\ddot{o}} \\
\ddot{0}\end{array}$ & $\begin{array}{c}\vdots \\
\vdots \\
\vdots\end{array}$ & 苛 & $\begin{array}{l}\ddot{0} \\
\stackrel{0}{0} \\
\ddot{0} \\
\ddot{0}\end{array}$ & $\begin{array}{l}\stackrel{\circ}{\ddot{0}} \\
\stackrel{0}{\ddot{0}} \\
\ddot{0}\end{array}$ & 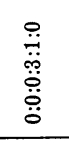 & 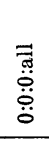 & $\begin{array}{l}\ddot{\ddot{o g}} \\
\ddot{0} \ddot{0} \\
\ddot{0}\end{array}$ & $\begin{array}{l}\stackrel{\bar{\sigma}}{0} \\
\ddot{0} \\
\ddot{0}\end{array}$ & 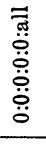 & 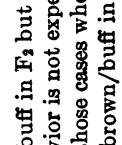 \\
\hline $\begin{array}{c}3 \\
0 \\
018 \\
0\end{array}$ & $\begin{array}{r}\vdots \\
\vdots \\
\vdots\end{array}$ & $\begin{array}{l}3 \\
0 \\
0 \\
3\end{array}$ & $\begin{array}{r}3 \\
0 \\
0 \\
018 \\
\end{array}$ & $\begin{array}{c}\leftarrow \\
\vdots \\
\vdots\end{array}$ & $\begin{array}{l}3 \\
0 \\
0\end{array}$ & $\begin{array}{l}R_{2}^{2} \mid: 2 \\
0 \\
018\end{array}$ & $\begin{array}{r}0 \\
0 \\
0\end{array}$ & $\begin{array}{c}m \\
0 \\
0 \\
0\end{array}$ & $\begin{array}{c}0 \\
0 \\
0 \\
0\end{array}$ & $\begin{array}{r}3 \\
0 \\
212 \\
\end{array}$ & $\begin{array}{l}2 \\
\vdots \\
0\end{array}$ & 2 & 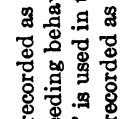 \\
\hline & 5 & & & 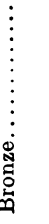 & & & 官 & & & 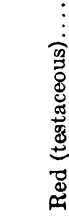 & & $\begin{array}{c}\vdots \\
\vdots \\
\vdots \\
\vdots \\
\vdots \\
\vdots \\
\vdots\end{array}$ & 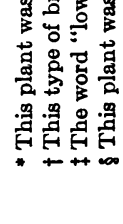 \\
\hline
\end{tabular}


buff and red colors are homozygous for $c$, buff being $P c R k$ and red, $P c$ $r k$. Furthermore, in the mottled beans the brown/buff is $P C c R k$ and the brown/red $P C c r k$. Whites, of course, are homozygous for $p$.

Using these assumptions, the $\mathrm{F}_{2}$ of this cross should segregate as follows : $18 P C c R k$ brown/buff : $6 P C c r k$ brown/red: $12 P C R k$ and $P C r k$ brown : $9 P$ $c R k$ buff : $3 P c r k$ red: $16 p$ white. The probability value, when the $\mathrm{F}_{2}$ data on 261 plants were fitted to this theoretical ratio, was 0.03 .

Gloyer presented $\mathrm{F}_{3}$ and $\mathrm{F}_{4}$ data. In his tables he included plants which were obviously different in color from the major part of the populations. These few cases should be disregarded because they were undoubtedly due to natural hybridization in the field. In a total population of $1,810 \mathrm{~F}_{3}$ plants, 28 of these off-types were obtained. This would be 1.5 per cent natural cross-pollination. $\mathrm{F}_{4}$ data need not be considered here because they were presented in such a way that one cannot judge whether the $\mathrm{F}_{4}$ progenies were from single plants. Some were numerically so large as to preclude such an assumption. The data on $\mathrm{F}_{3}$ plants are also summarized in table 8 . If the assumptions made to explain the $F_{2}$ ratios are correct, the $F_{3}$ ratios should fall into certain patterns. The mottled types should not breed true but should segregate mottled and self-colored in the ratio of $1: 1$.

In the brown/buff, segregation for $P, C$, and $R k$ is expected. Four progenies segregated for these three genes. Four progenies also segregated for $P$ and $C$. In these cases no red or mottled-on-red beans are expected. Four progenies segregated for $C$ and $R k$. Here no whites are expected. Six progenies segregated for only $C$, giving 1 brown : 2 brown/ buff : 1 buff. The fit to this ratio was not very close, the probability value being 0.01 . One progeny test of a buff $\mathrm{F}_{2}$ behaved as a brown/buff segregating for $C c$. It was probably misclassified in $\mathrm{F}_{2}$.

$\mathrm{F}_{3}$ progenies from the brown/red should have segregated for only $P$ and $C$. No buff or buff-mottled beans are expected in any of the progenies. Six progenies segregated for $P$ and $C$ and three for $C$ only.

The brown $\mathrm{F}_{2}$ were grouped into two color classes, seal brown and bronze. If all browns are classed together the breeding behavior is similar in both types. According to the assumptions here proposed by the present author these browns are of the constitution $P C R k$ or $P C r k$. They should segregate for the $P$ gene only. As a matter of fact, some buffs and reds appeared in the progeny tests-a result not expected on these assumptions because buffs and reds are both homozygous for $c$. In order to segregate these colors the brown beans would have to be $P C c$ $R k r k$; but brown beans cannot be heterozygous for $C$, for these are al- 
ways mottled. It is likely, therefore, that these assumptions will have to be amplified to explain the breeding behavior of the brown segregates. Since Gloyer recognized a number of brown colors presumably due to other modifiers this is not fatal to the remainder of the hypothesis.

The buff plants may segregate for $P$ and $R k$. One segregated for both and two for $R k$ only. In addition, one progeny test was made of a brown/ buff $\mathrm{F}_{2}$ which behaved as a buff in $\mathrm{F}_{3}$, segregating for $R k$. The red (testaceous) plants should segregate for $P$ or breed true. One segregated for $P$ and two bred true. The whites, being $p$ white, should all breed true and the results of twelve progeny tests agreed with the expectation. However, 3 plants with colored beans were found in 491 white $\mathrm{F}_{3}$ plants ; these were undoubtedly due to natural hybridization.

The assumption of three segregating genes, $P, C$, and $R k$ will explain most of the results of this cross. A supplementary hypothesis must be made to explain the breeding behavior of some brown beans. This, however, is beyond the purpose of this review which was made to show that the $R k$ gene has been noted in the literature but the relation between the dominant and recessive allelomorphs was not recognized.

\section{WHITE KIDNEY $\times$ NAGAZURA}

White segregates taken from $F_{3}$ White Kidney $\times$ Red Kidney, were used as parents in crosses with Nagazura. The white used as the pistillate parent in cross 34.160 was a segregate in an $F_{3}$ population from a buff $\mathrm{F}_{2}$ (table 6 ). This buff was segregating for $P$ and $R k$. These whites could be $p m R k$ or $p m r k$. The presence of $B l$ or $b l$ could not be told since $B l$ does not modify the color of buff beans. The white used as the pistillate parent in cross 34.161 segregated from a purple/buff $\mathrm{F}_{2}$ plant (table 6). This white should be $p M R k B l$ since the $\mathrm{F}_{3}$ test showed segregation for $P$ only. These two whites differed in that one carried $M$, the other $m . \mathrm{F}_{2}$ populations of these crosses showed there were actually four white genotypes : $p m r k B l, p m R k B l, p M r k B l$, and $p M R k B l$. The results of these genotypes used in crosses with Nagazura ( $P M R k b l$ ) are shown in tables 9-11.

The third type of segregation was hardly expected because in the $\mathrm{F}_{3}$ family in which the white parental strain appeared there were no testaceous or testaceous mottled beans, so they were assumed to be $R k$. Possibly the $\mathrm{F}_{3}$ population was not large enough to recover the $r k$ genotypes. All the whites used were homozygous for $B l$.

In cross $34.160 a$ (formula : $p m r k B l \times P M R k b l$ ), four genes should segregate. The $\mathrm{F}_{2}$ data fitted to a $81: 27: 27: 9: 36: 12: 64$ ratio gave a probability value of 0.27 . The results of $\mathrm{F}_{2}$ and $\mathrm{F}_{3}$ are summarized in 
[Vol. 12, No. 9

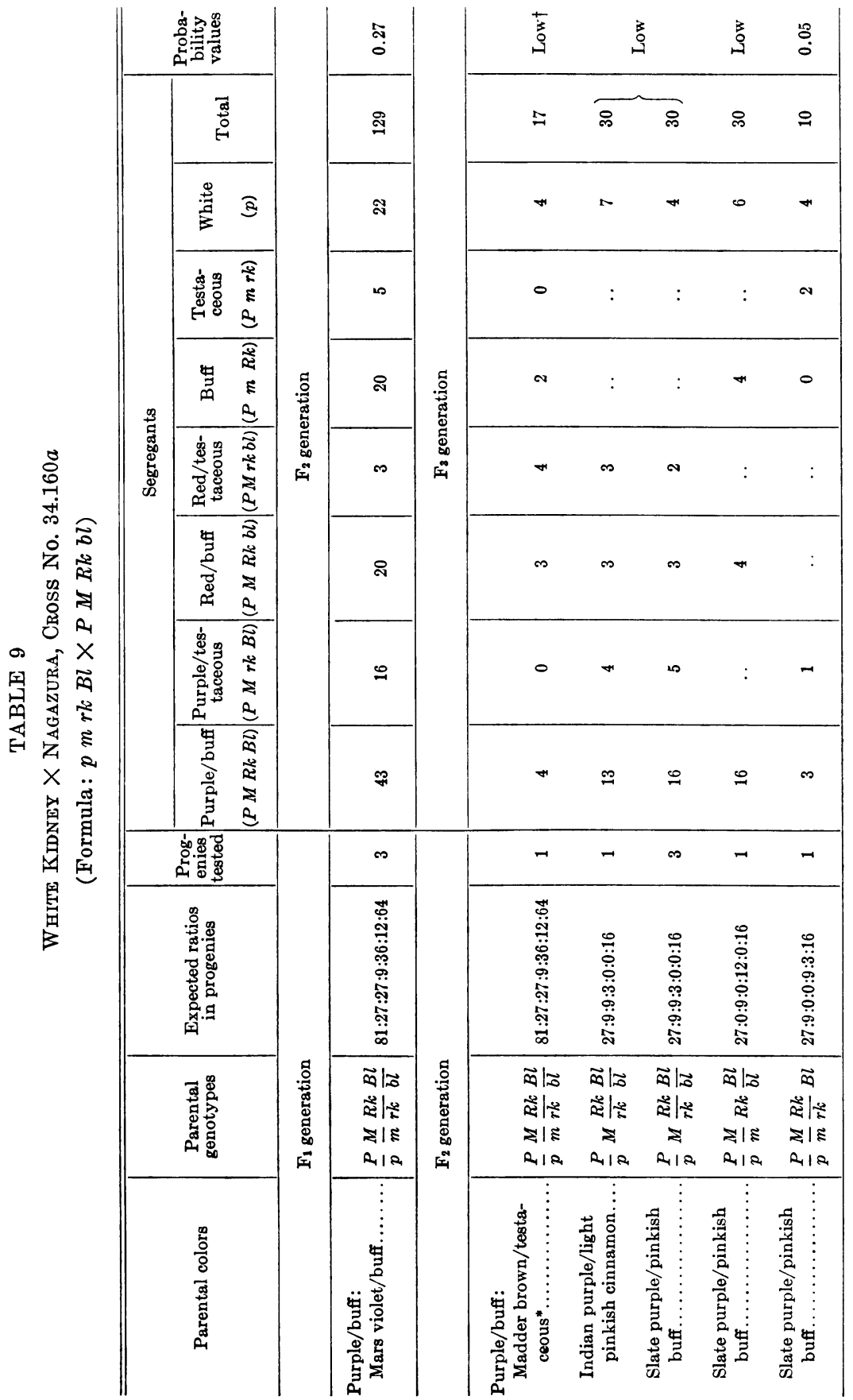




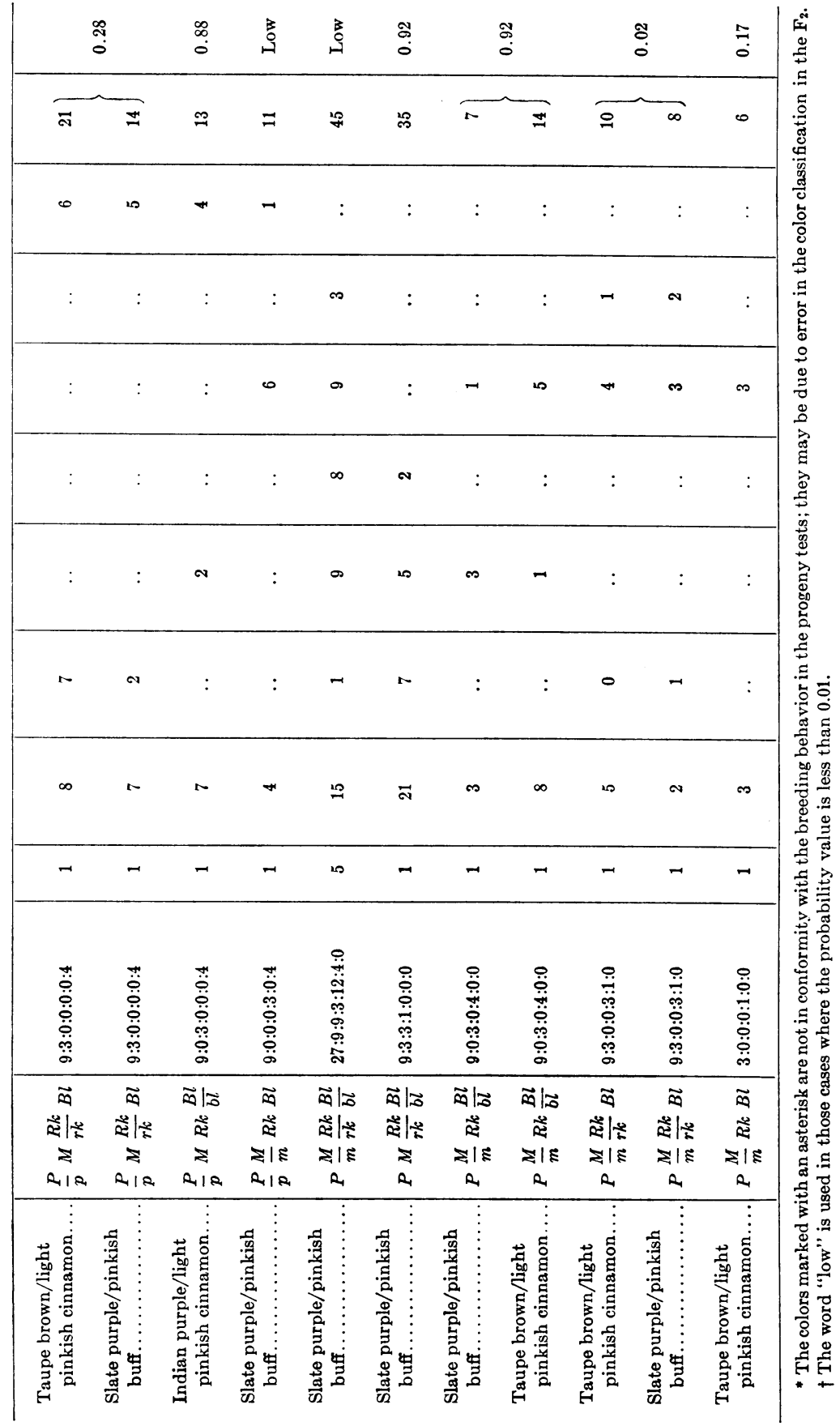




\begin{tabular}{|c|c|c|c|c|c|c|c|c|c|c|c|c|c|}
\hline & & 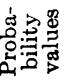 & & & & 은 & 苂 & $\frac{9}{0}$ & $\stackrel{28}{0}$ & & $\begin{array}{l}\circledast \\
0 \\
0\end{array}$ & $\stackrel{\mathscr{*}}{0}$ & $\begin{array}{l}0 \\
0 \\
0\end{array}$ \\
\hline & & 永 & & & $\infty$ & $\dddot{m}$ & 으 & $\infty$ & $\infty$ & $\widehat{ล}$ & $F$ & $\Xi$ & 10 \\
\hline & & & $\widehat{2}$ & & $\infty$ & $\infty$ & $N$ & : & : & $N$ & $\infty$ & + & - \\
\hline & & 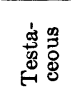 & 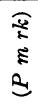 & & $\infty$ & $\infty$ & : & $\infty$ & : & : & : & : & : \\
\hline & $\stackrel{+2}{ \pm=}$ & $\stackrel{4}{\Xi}$ & 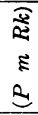 & : & : & : & : & : & : & on & $\infty$ & : & $:$ \\
\hline $\begin{array}{l}0 \\
8 \\
0 \\
+1\end{array}$ & 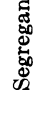 & 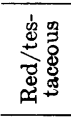 & $\begin{array}{l}5 \\
5 \\
5 \\
5 \\
5\end{array}$ & 点 & $r$ & $\infty$ & 0 & $\infty$ & $\omega$ & : & : & $\infty$ & : \\
\hline 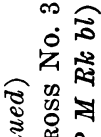 & & 峞 & $\begin{array}{l}5 \\
0 \\
3 \\
3 \\
3 \\
3\end{array}$ & & : & : & : & : & : & $\stackrel{20}{\prime}$ & ন & + & $H$ \\
\hline 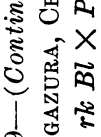 & & 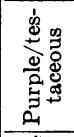 & 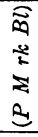 & & N & $\nabla$ & N & $\sim$ & 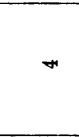 & : & : & : & : \\
\hline 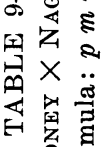 & & 崖 & 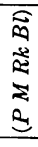 & & $:$ & : & : & : & : & : & : & : & $:$ \\
\hline 四 & & 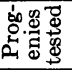 & & & - & - & - & - & $\rightarrow$ & N & $N$ & $\neg$ & $\rightarrow$ \\
\hline$\stackrel{9}{3}$ & & 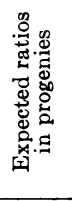 & & & 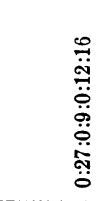 & 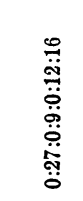 & 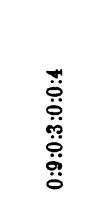 & 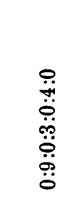 & & 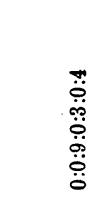 & 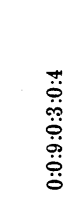 & 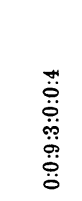 & 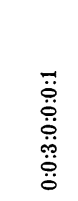 \\
\hline & & 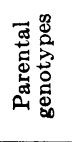 & & 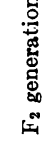 & $\begin{array}{c}\overrightarrow{0} 1: 5 \\
\vdots \\
21 E \\
218\end{array}$ & 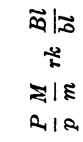 & 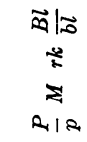 & 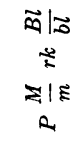 & $\begin{array}{c}\vec{\nabla} \mid \approx 0 \\
\vdots \\
\vdots \\
2\end{array}$ & $\begin{array}{c}\overrightarrow{0} \\
\overrightarrow{2} \\
\Sigma 15 \\
018\end{array}$ & 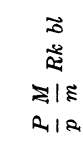 & 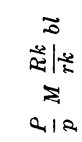 & $\begin{array}{l}\overrightarrow{0} \\
\overrightarrow{2} \\
\Sigma \\
0,18\end{array}$ \\
\hline & & 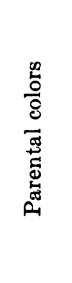 & & & 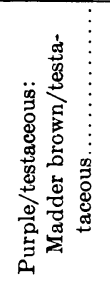 & 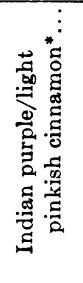 & 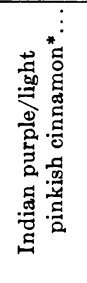 & 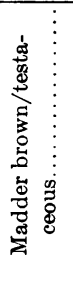 & 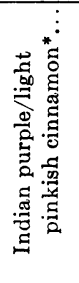 & 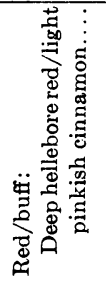 & 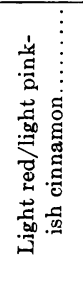 & 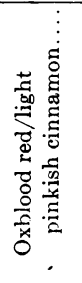 & 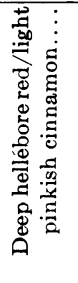 \\
\hline
\end{tabular}




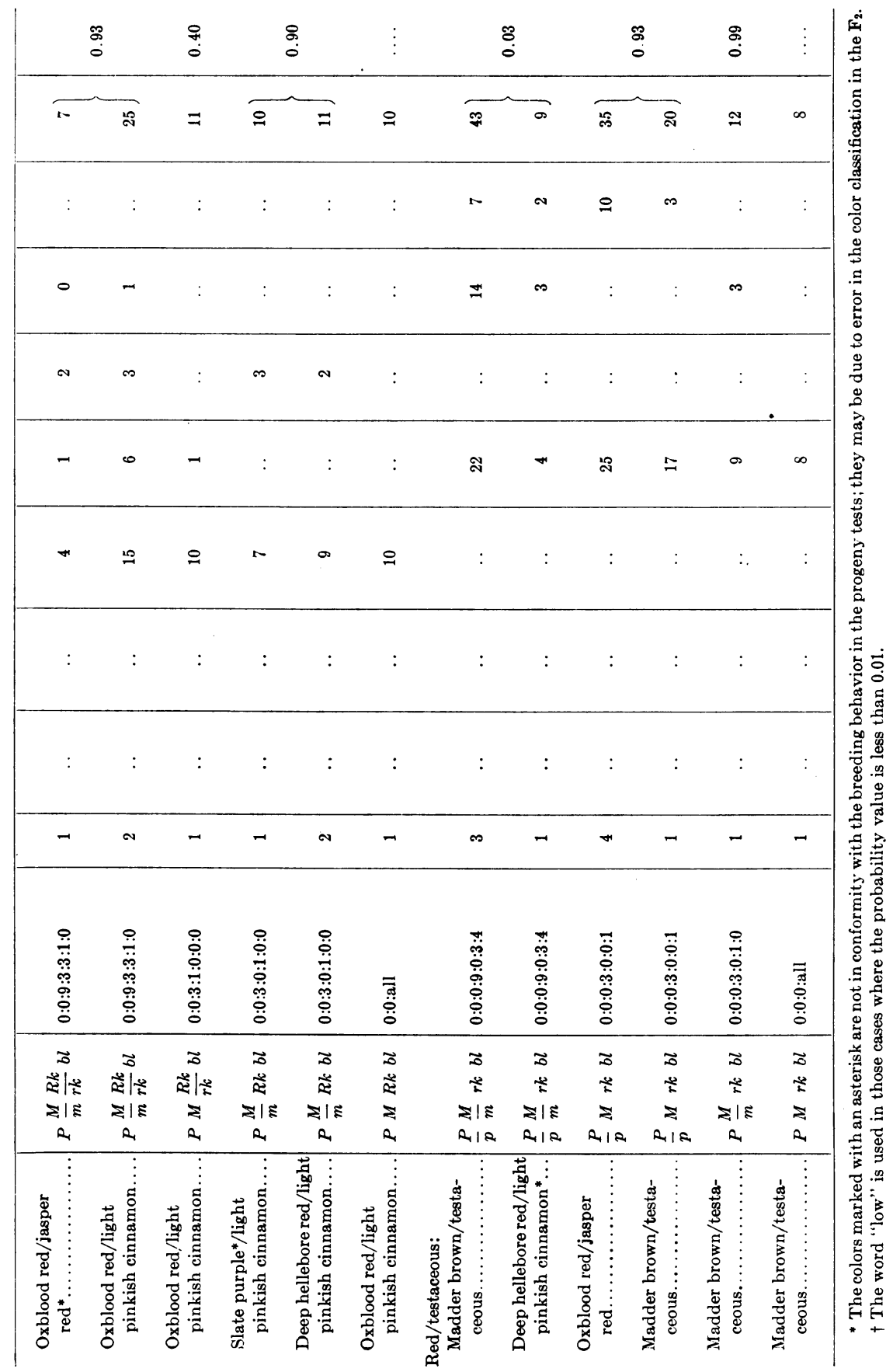


table 9 . There were a number of colors in $\mathrm{F}_{3}$ which were grouped in the following way : purple/buff included raisin black/pinkish buff (plate 1, fig. 9) ; Indian purple/pinkish buff (plate 1, fig. 10); and dark heliotrope slate/pinkish buff (plate 1, fig. 11). Purple/testaceous included raisin black/testaceous (plate 1, fig. 12) and Indian purple/testaceous (plate 1, fig. 13). Red/buff included oxblood red/pinkish buff (plate 1, fig. 15), maroon/pinkish buff (plate 1, fig. 14) ; and deep hellebore red/ pinkish buff (plate 1, fig. 16). Red/testaceous included oxblood red/ testaceous (plate 1, fig. 22) and maroon/testaceous (plate 1, fig. 17). Buff was classed as pinkish cinnamon (plate 1, fig. 7), testaceous as testaceous (plate 1, fig. 1) and white as white (plate 1, fig. 33).

The $\mathrm{F}_{2}$ color descriptions in general were similar to those of $\mathrm{F}_{3}$. In one case madder brown was chosen as the standard color. This was an unfortunate choice because both reddish purple and reds were classed in this group. Had colors been chosen a little farther off this borderline description, the $\mathrm{F}_{3}$ results would appear more convincing. As it is, some madder-brown mottled beans showed in their breeding behavior to be carrying $B l$ and others were homozygous for $b l$. Progeny tests also showed that $P M R k$ and $P M r k$ genotypes were not always clearly distinguishable. Some beans described as mottled on buff bred as mottled on testaceous and vice versa. $\mathrm{F}_{3}$ progeny tests of the purple/buff phenotype showed that one $\mathrm{F}_{2}$ plant was segregating for $P, M, R k$, and $B l$. The poor fit is due to the small number of 17 plants, where 256 were needed to recover all genotypes. Four segregated for $P, R k$, and $B l$. Here a poor fit was obtained because fewer red/buff types appeared than were expected. One segregated for $P, M$, and $B l$; one for $P, M$, and $R k$; two for $P$ and $R k$; one for $P$ and $B l$; one for $P$ and $M$; five for $M, R k$, and $B l$; one for $R k$ and $B l$; two for $M$ and $B l$; two for $M$ and $R k$; and one for $M$.

Of the purple/testaceous $\mathrm{F}_{2}$ plants subjected to progeny tests, two segregated for $P, M$, and $B l$; one for $P$ and $B l$; and one for $B l$. In the $\mathrm{F}_{3}$ progenies from red/buff four segregated for $P$ and $M$; one for $P$ and $R k$; one for $P$, three for $M$ and $R k$; one for $R k$; three for $M$; and one bred true. Four progenies of red/testaceous segregated for $P$ and $M$; five for $P$; one for $M$; and one bred true.

With some exceptions, probably caused by misjudgment of color of $\mathrm{F}_{2}$ plants, these results bear out the assumption that the white parent was $p m r k B l$. In some cases the size of the population in $\mathrm{F}_{3}$ was too small for very good agreement with expectancy.

In the $\mathrm{F}_{1}$ of cross $34.160 b$ (formula: $p m R k B l \times P M R k b l$ ), $R k$ was homozygous, so no mottled-on-testaceous or self-colored testaceous beans were expected. Three genes were segregating in $\mathrm{F}_{2}, P, M$, and $B l$, 
giving a $27: 9: 12: 16$ ratio. The $\mathrm{F}_{2}$ results fitted to this ratio gave a probability value of 0.13 .

The purple/buff $\mathrm{F}_{2}$ plants were slate-purple/pinkish buff and Indian purple/light pinkish cinnamon (plate 1, fig. 10). Both gave results in conformity with expectation. This phenotype may segregate for $P, M$, and $B l$. Two segregated for $P, M$, and $B l$; three for $P$ and $M$; three for $P$ and $B l$; two for $M$ and $B l$; four for $P$; two for $B l$; two for $M$; and one bred true. The red/buff phenotypes were oxblood red/light pinkish cinnamon (plate 1, fig. 15) and light red/light pinkish cinnamon. This phenotype should segregate for only $P$ and $M$. Three progenies segregated for $P$ and $M$; four for $M$; and five bred true. These results, as shown in table 10, are all in conformity with the assumption that the white parent was $p m R k B l$.

In cross $34.161 a$ (formula: $P M r k B l \times P M R k b l$ ), $M$ was homozygous so no self-colored types were expected. The segregating genes were $P, R k$, and $B l$. The $\mathrm{F}_{2}$ results from two progenies of this cross were as follows : Purple/buff, 73 ; purple/testaceous, 12 ; red/buff, 26 ; red/ testaceous, 8 ; and white, 26. Fitted to the theoretical ratio of $27: 9: 9: 3$ : 16 there should be in a population of $145,61.2$ purple/buff, 20.4 purple/ testaceous, $20.4 \mathrm{red} / \mathrm{buff}, 6.8 \mathrm{red} /$ testaceous, and 36.2 white plants. The probability value for such a fit is $0.07 . \mathrm{No}_{3}$ progeny tests were made of this cross.

In cross $34.161 b$ (formula: $p M R k B l \times P M R k b l$ ), $M$ and $R k$ were both homozygous ; therefore segregation for only $P$ and $B l$ was expected in the hybrid. No self-colored or mottled beans with a testaceous background were expected. The results of this cross are presented in table 11. The $\mathrm{F}_{2}$ results fitted to a $9: 3: 4$ ratio gave a probability value of 0.01 , owing to the small number of white beans. However, the results from $\mathrm{F}_{3}$ fitted the expectations very well. The purple/buff were all slate purple/ pinkish buff. Four progenies in $\mathrm{F}_{3}$ segregated for $P$ and $B l$; two for $P$; four for $B l$; and one bred true. The red/buff which were classified as oxblood red/light pinkish cinnamon in $\mathrm{F}_{2}$ should have segregated for $P$ or bred true because $M$ and $R k$ were homozygous. Two progenies tested in $\mathrm{F}_{3}$ segregated for $P$ and five bred true.

The experiments with the whites of known genotypes bear out the conclusions made in the earlier tests. Mottling is due to the presence of a single gene, $M$; in the presence of its recessive allelomorph $m$, the beans are self-colored. The $R k$ gene can be distinguished in both mottled and self-colored beans. In mottled beans the ground color is buff if $R k$ is present and testaceous if $r k$ is present; in self-colored beans $R k$ is buff and $r l k$ is testaceous. $B l$ may be carried in white, testaceous, and buff 


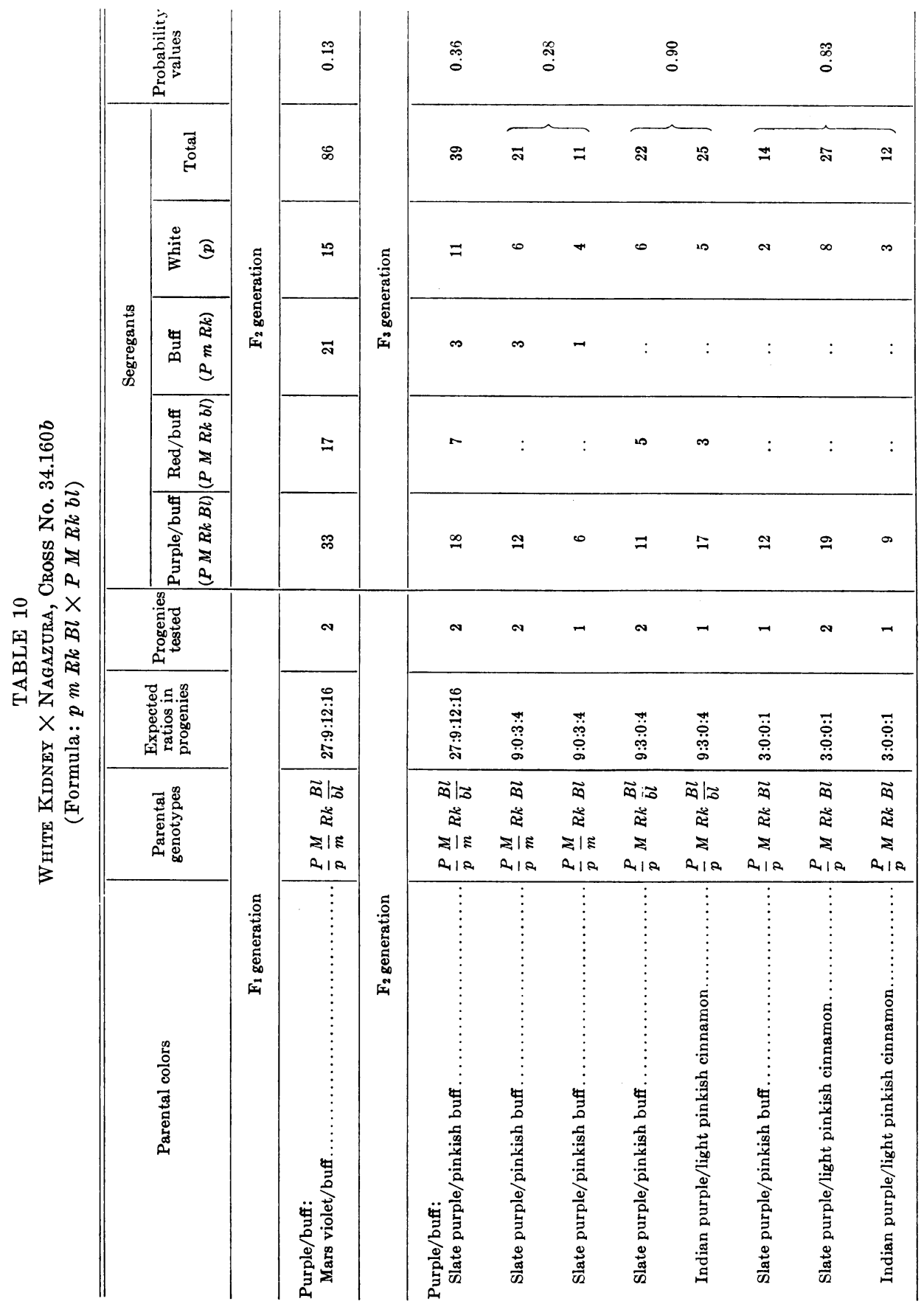




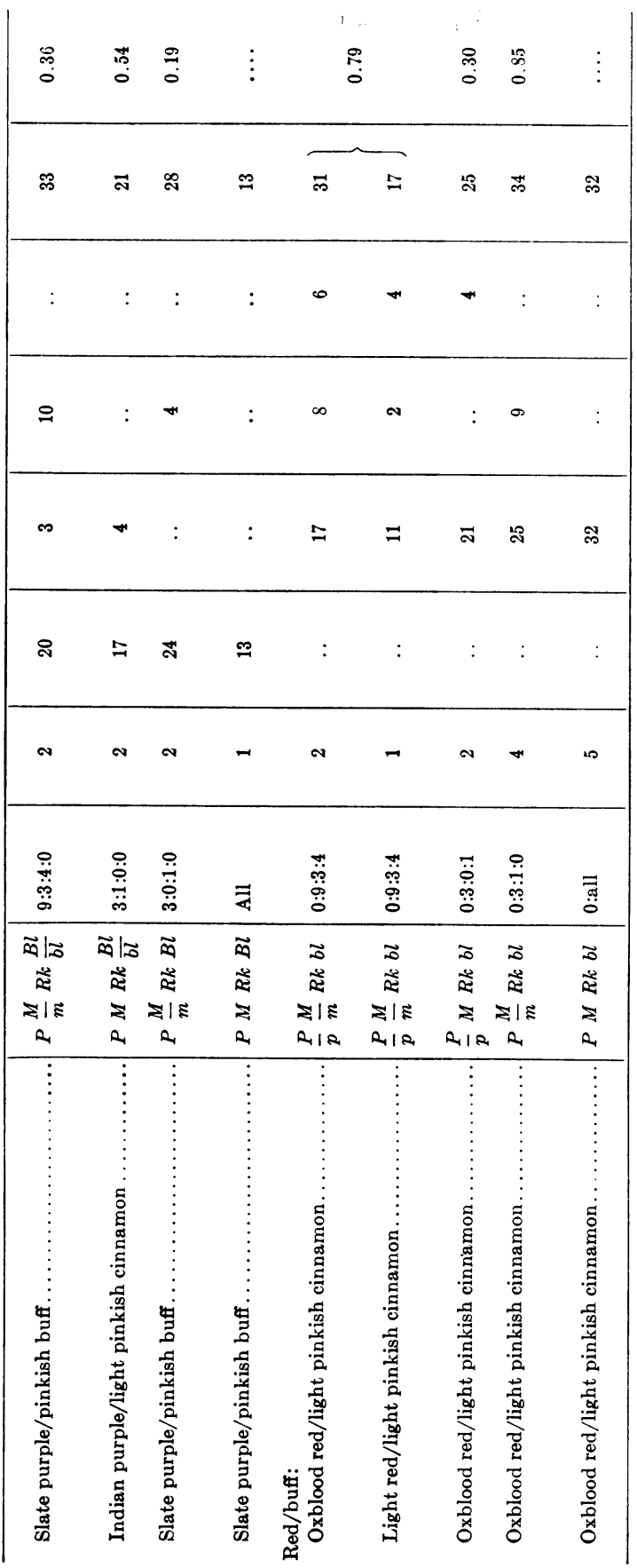


[VoL. 12, No. 9

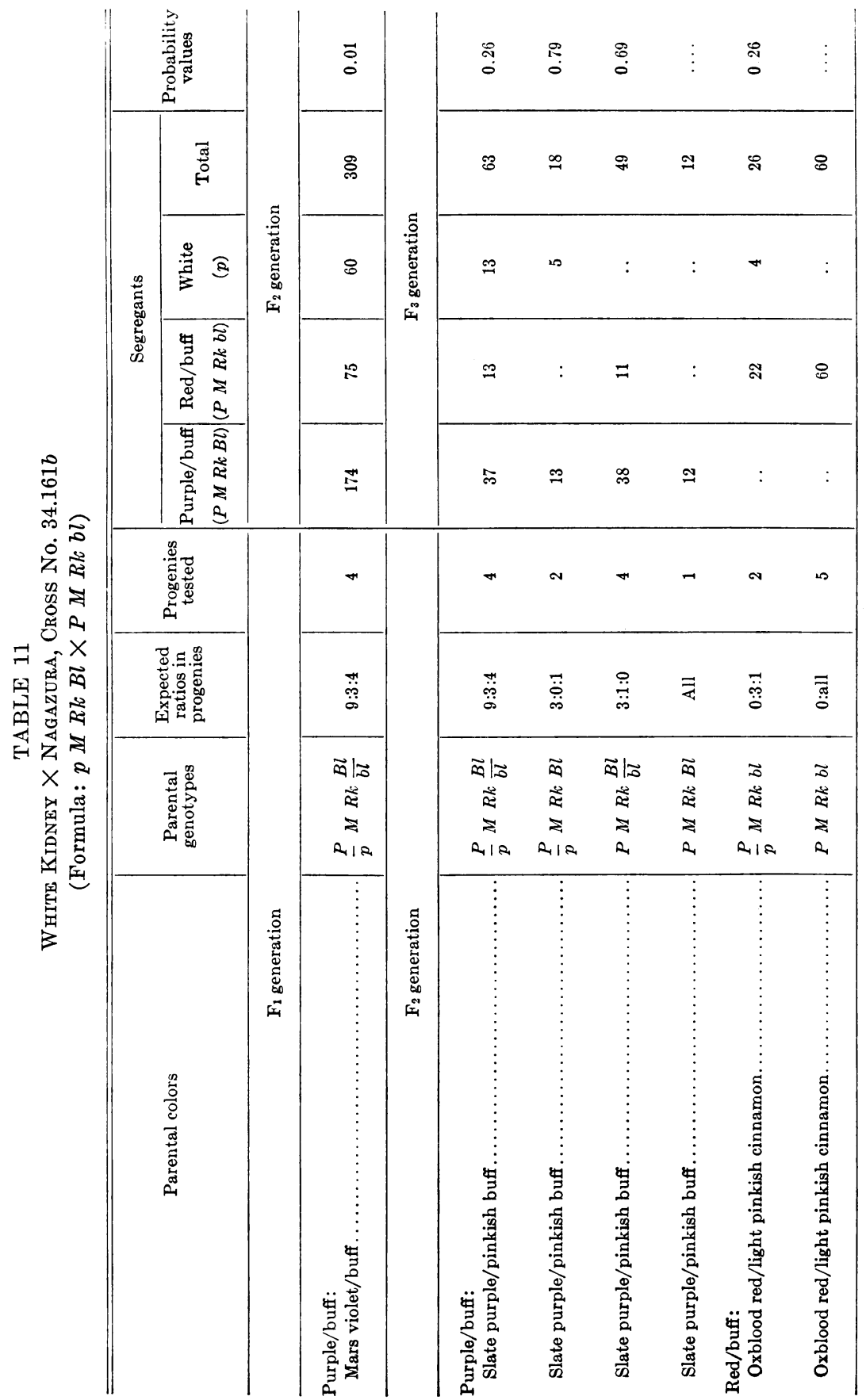


beans with no modification in the expression of color. When $B l$ is added to a red-mottled bean the mottling is changed from red to purple. There is no indication of linkage between $M, B l$, or $R k$.

\section{RED KIDNEY $\times$ CHINA RED, AND RECIPROCAL}

(Formulas: $P r r k B l \times P R R k b l$ and $P R R k b l \times P r r k B l$ )

Since both of these varieties were colored they were homozygous for $P$. The China Red is a dark-red bean (plate 1 , fig. 6 ) which matches very closely Ridgway's (18) oxblood red or is even a little darker-Victoria lake. The $\mathrm{F}_{1}$ plants of these crosses were all mottled. If this mottling were due to a heterozygous color gene the ratio of mottled to self-colored in $\mathrm{F}_{2}$ should be $1: 1$; actually it was $134: 107$. In the $\mathrm{F}_{2}$ segregants eight color types were obtained. Among these were the familiar buff and testaceous. This cross then, was segregating for $R k$. The presence of $R k$ explains the two ground colors, buff and testaceous in the mottled beans. The action of $B l$ can also be seen in the mottled beans, some being purple mottled, others red. Two other self-colors were obtained in $\mathrm{F}_{2}$ : purple (plate 1, figs. 23, 24) and oxblood red (plate 1, fig. 25). To account for these, the assumption was made that China Red has a red gene similar to, if not identical with Lamprecht's (14) $R$ which produces mottling when heterozygous; Red Kidney is homozygous for $r$. Segregation for three genes explained the results if the following assumptions for the genotypes were made : $R r R k B l$ is purple/buff; $R r r k B l$ is purple/testaceous ; $R r R k b l$ is red/buff and $R r r k b l$ is red/testaceous. Purple may be $R R k B l$ or $R r k B l$; oxblood red may be $R R k b l$ or $R r k b l$; buff may be $r R k B l$ or $r R k b l$; and testaceous, $r r k B l$ or $r r k b l$. The expected ratio should be $18: 6: 6: 2: 12: 4: 12: 4$, respectively, for the eight colors. These assumptions were tested in progenies from $\mathrm{F}_{2}$ plants. All mottled $\mathrm{F}_{2}$ beans should segregate mottled and self-colored in the ratio of 1:1. The colors would depend on the interaction of $R k$ and $B l$.

The purple/buff $\mathrm{F}_{2}$ should segregate for $R, R k$, and $B l$. Since the mottling is due to $R r$, no mottled types should breed true. It is possible, however, for some to be homozygous for $R k$ or $B l$. Some $\mathrm{F}_{2}$ progenies bred in $\mathrm{F}_{3}$ as purple/buff but the colors noted for the $\mathrm{F}_{2}$ plants were not purple/buff. These plants are indicated in table 12 by an asterisk following the color which is not in conformity with the breeding behavior.

Seventeen $\mathrm{F}_{2}$ purple/buff segregated for $R, R k$, and $B l$ in $\mathrm{F}_{3}$; six segregated for $R$ and $R k$; three for $R$ and $B l$; and four for $R$.

Thirteen $\mathrm{F}_{2}$ purple/testaceous plants were tested in $\mathrm{F}_{3}$; since $r k$ was present in this genotype segregation for only $R$ and $B l$ was expected. Nine segregated for $R$ and $B l$ and four for $R$. 


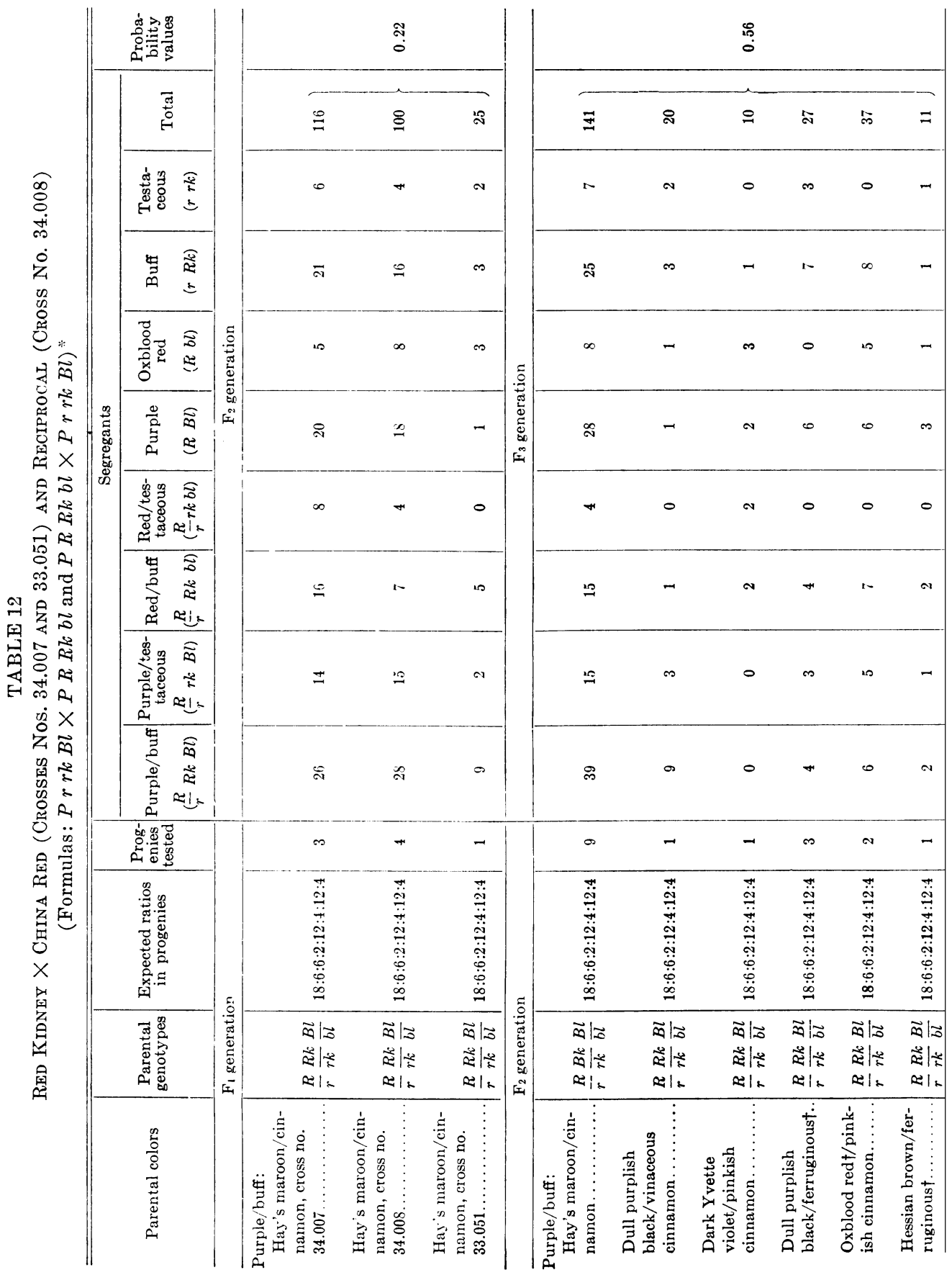




\begin{tabular}{|c|c|c|c|c|c|c|c|c|c|c|c|c|c|}
\hline \multicolumn{4}{|c|}{$\begin{array}{l}= \\
0\end{array}$} & \multicolumn{3}{|c|}{ 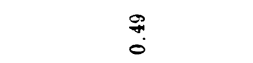 } & \multicolumn{3}{|c|}{$\div$} & \multicolumn{3}{|c|}{$\vec{b}$} & $\begin{array}{l}\text { की } \\
\Xi\end{array}$ \\
\hline $\overrightarrow{~ ह ै ~}$ & $\underset{ల}{\infty}$ & สิ & 0 & $\stackrel{\infty}{\sim}$ & $\cong$ & $\infty$ & ন & 0 & $\infty$ & م) & 安 & $\vec{n}$ & \\
\hline 0 & מת & מo & - & : & : & : & : & : & : & $\cong$ & os & $\cong$ & \\
\hline$\infty$ & $\infty$ & 0 & 0 & $\sigma$ & 0 & $\omega$ & os & $\infty$ & $\therefore$ & : & : & : & \\
\hline : & : & : & : & - & - & - & : & : & : & $\omega$ & $\infty$ & $\infty$ & \\
\hline I & $=$ & $\sigma$ & $\infty$ & $\sigma$ & $\sigma$ & $\infty$ & is & 0 & - & $\cong$ & $=$ & 우 & \\
\hline : & : & : & : & : & : & : & : & : & : & 0 & D & 웅 & \\
\hline : & : & : & : & + & N & : & : & : & : & : & : & : & \\
\hline 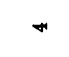 & N & 0 & 0 & : & : & : & : & : & : & ล & 9 & $\mathscr{1}$ & \\
\hline$\stackrel{7}{ }$ & $\cong$ & 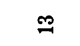 & ๙ & $\infty$ & 0 & 0 & 으 & $\infty$ & מمו & : & : & : & \\
\hline$\sim$ & N & - & - & - & - & - & N & - & - & r & $\infty$ & $\sim$ & \\
\hline 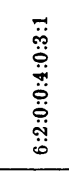 & 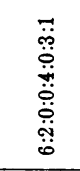 & 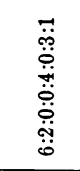 & 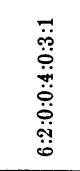 & 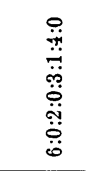 & 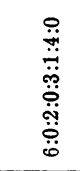 & 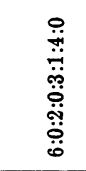 & & 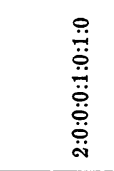 & بِّبة & 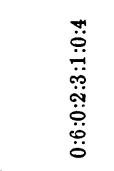 & 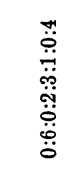 & 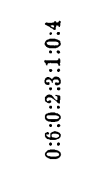 & 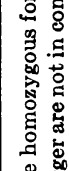 \\
\hline 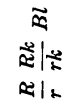 & 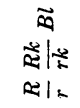 & 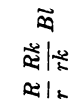 & 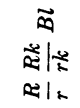 & 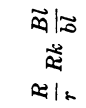 & 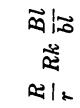 & 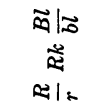 & \begin{tabular}{l}
$\vec{a}$ \\
\multirow{2}{*}{} \\
21.
\end{tabular} & 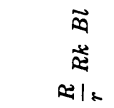 & $\begin{array}{l}\vec{\infty} \\
\overrightarrow{x^{2}} \\
0=1 \text {. }\end{array}$ & 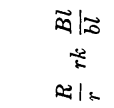 & 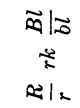 & 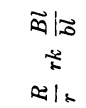 & 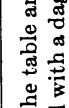 \\
\hline 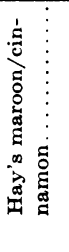 & 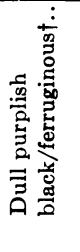 & 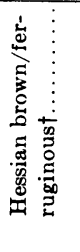 & 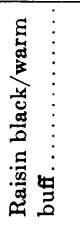 & 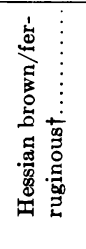 & 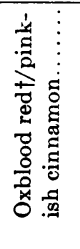 & 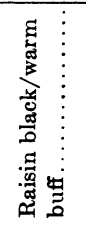 & 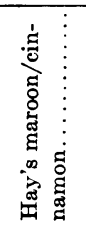 & 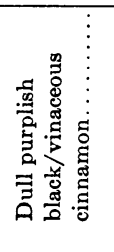 & 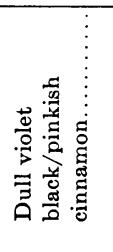 & 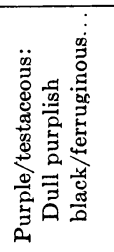 & 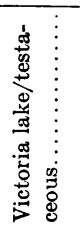 & 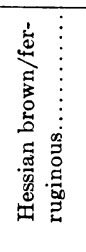 & 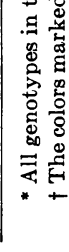 \\
\hline
\end{tabular}




\begin{tabular}{|c|c|c|c|c|c|c|c|c|c|c|c|c|}
\hline & & 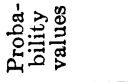 & & & $\begin{array}{l}\stackrel{0}{\circ} \\
\dot{0}\end{array}$ & & & & & & $\stackrel{\ddot{\oplus}}{\circ}$ & \\
\hline & & ${ }_{\vec{H}}^{\bar{\sigma}}$ & & 8 & $\infty$ & $F$ & is & $\stackrel{\varrho}{\sim}$ & ฒ & $\dddot{m}$ & 용 & $\approx$ \\
\hline $\begin{array}{c}\infty \\
8 \\
\stackrel{0}{0}\end{array}$ & & 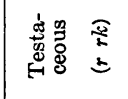 & & $\infty$ & $\boldsymbol{N}$ & 0 & $N$ & $\rightarrow$ & 0 & $:$ & : & : \\
\hline $\begin{array}{l}\dot{0} \\
Z_{2} \\
v_{2}\end{array}$ & & 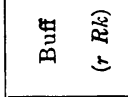 & & : & : & $\dddot{1}$ & $\infty$ & $\infty$ & מת & $\infty$ & tis & 10 \\
\hline 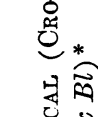 & & $\begin{array}{ll}\ddot{8} & \approx \\
0 & 0 \\
0 & 0 \\
0\end{array}$ & & : & : & $\sigma^{\prime \prime}$ & 오 & + & $\infty$ & 오 & s & $\approx$ \\
\hline 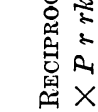 & 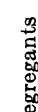 & 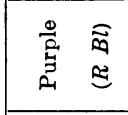 & 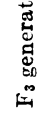 & $\overrightarrow{\mathrm{N}}$ & -1 & : & : & : & : & : & : & : \\
\hline 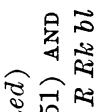 & ఝ & 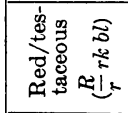 & & : & : & $\infty$ & $\exists$ & -1 & + & : & : & : \\
\hline 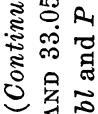 & & 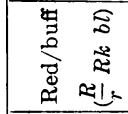 & & : & : & $\overrightarrow{\text { N }}$ & $\approx$ & $n$ & 0 & $\stackrel{20}{-2}$ & $\overrightarrow{7}$ & $\approx$ \\
\hline 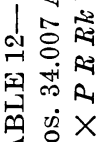 & & 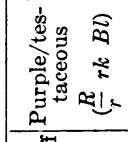 & & ฉ્స & os & : & : & : & : & $:$ & : & : \\
\hline 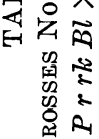 & & 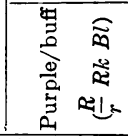 & & : & : & : & : & : & : & : & : & : \\
\hline 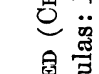 & & 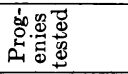 & & $\infty$ & $\neg$ & $\infty$ & $H$ & - & N & $\neg$ & $\pi$ & N \\
\hline 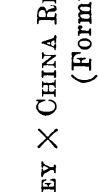 & & 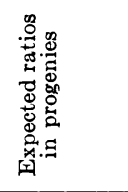 & & 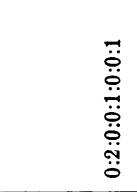 & 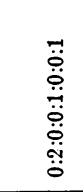 & 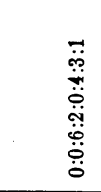 & 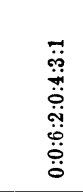 & 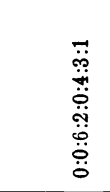 & 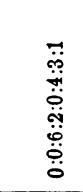 & 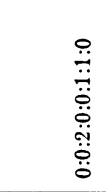 & 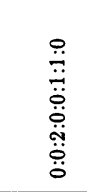 & 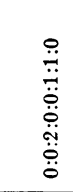 \\
\hline 㼙 & & 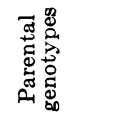 & 宽 & 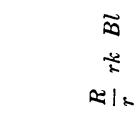 & $\begin{array}{c}\vec{\infty} \\
\vdots \\
2=1=\end{array}$ & $\begin{array}{l}\overrightarrow{0} \\
\overrightarrow{2} \mid: 2 \\
21:\end{array}$ & $\begin{array}{l}\overrightarrow{0} \\
\overrightarrow{2} \mid+2 \\
2=1:\end{array}$ & $\begin{array}{l}\overrightarrow{0} \\
\overrightarrow{02} \mid ث \\
01 .\end{array}$ & \begin{tabular}{l}
$\approx$ \\
\multirow{2}{*}{$\mid \stackrel{2}{2}$} \\
सा
\end{tabular} & 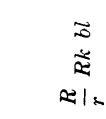 & 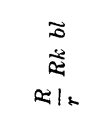 & 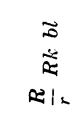 \\
\hline & & 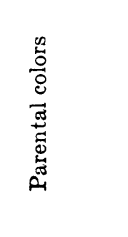 & & 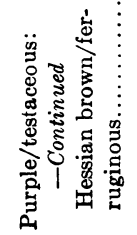 & 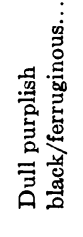 & 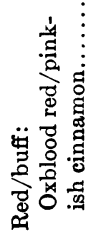 & 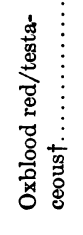 & 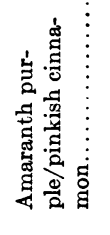 & 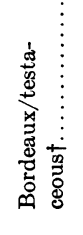 & 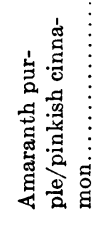 & 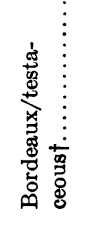 & 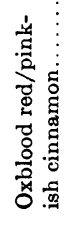 \\
\hline
\end{tabular}




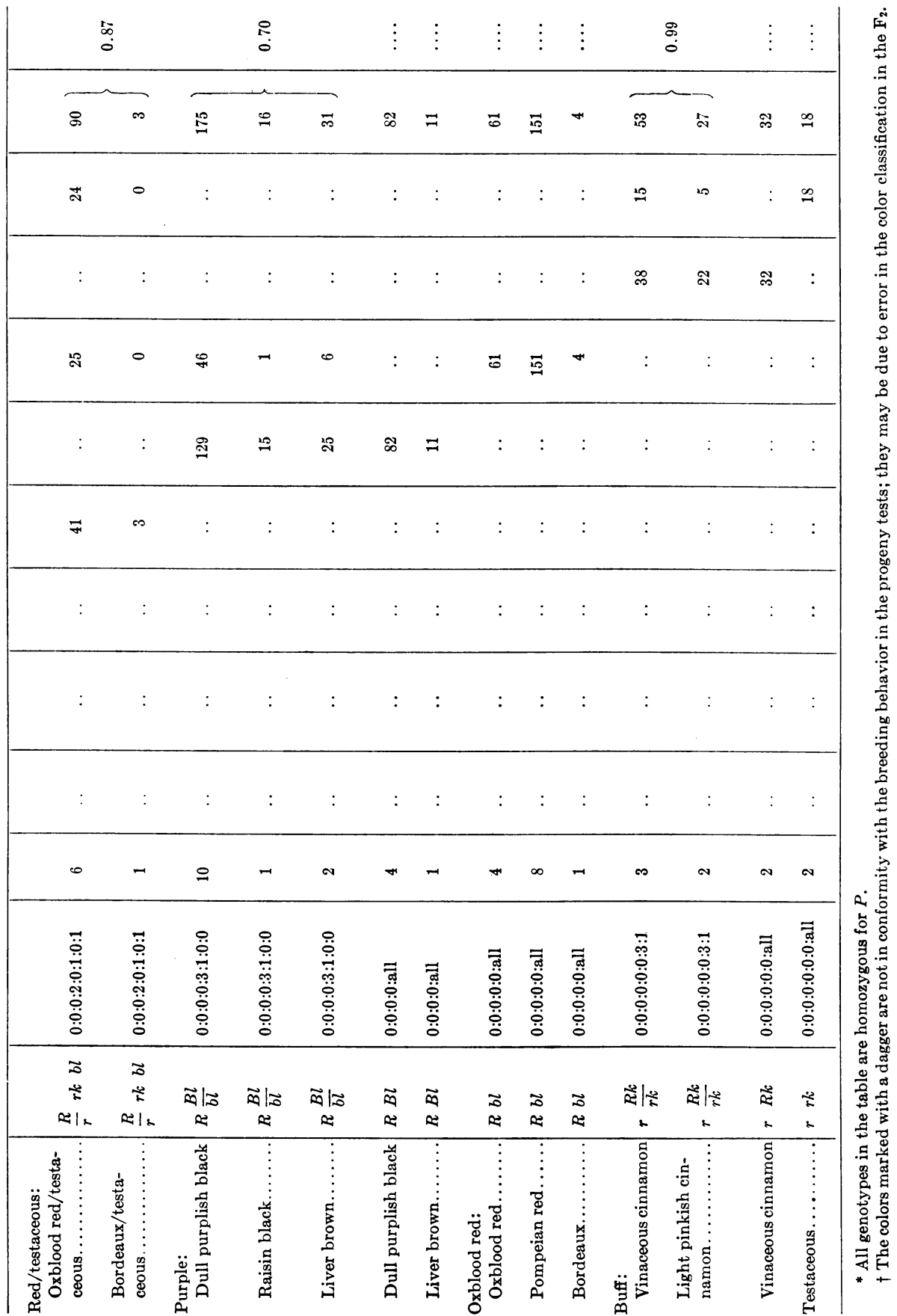


Seventeen $\mathrm{F}_{2}$ red/buff were tested in $\mathrm{F}_{3}$. Some of these had been misclassified as red/testaceous in $\mathrm{F}_{2}$. Since red/buff is $R r R k b l$ segregation for only $R$ and $R k$ is possible. Ten progenies segregated for $R$ and $R k$, and seven for $R$.

Seven red/testaceous $\mathrm{F}_{2}$ plants were tested in $\mathrm{F}_{3}$. This genotype, being $R r r k b l$, should segregate for $R$ only, giving $1 R r k b l$ oxblood red: $2 R r r k b l$ red/testaceous : $1 r r k b l$ testaceous. The numbers obtained were $25: 44: 24$. If the assumptions made were correct, the purple $\mathrm{F}_{2}$ should segregate for $B l$ only. Thirteen progenies segregated for $B l$ and five bred true. All oxblood red phenotypes should breed true. The thirteen tested conformed to expectation. The buff phenotypes should segregate for $R k$ or breed true. Five segregated for $R k$ and two bred true. Only two testaceous $\mathrm{F}_{2}$ were grown in $\mathrm{F}_{3}$ and they bred true as expected.

\section{CHINA RED $\times$ RED KIDNEY}

(Formula: $P R r k b l \times P r r k B l$ )

In this cross the $\mathrm{F}_{1}$ was purple/testaceous rather than purple/buff as in the crosses reported in table 12. The China Red in this cross must have been $P R r k b l$ while in the others it was $P R R k b l$. The $\mathrm{F}_{2}$ was in conformity with expectations in that no buff or mottled-on-buff beans appeared. The $\mathrm{F}_{3}$ progenies grown from $\mathrm{F}_{2}$ plants were all homozygous for $r k$. Seventeen purple/testaceous $\mathrm{F}_{2}$ plants were tested in $\mathrm{F}_{3}$. Eight of them segregated for $R$ and $B l$ and nine segregated for $R$ only. Seven red/testaceous segregated for $R$ as expected. Five purple $\mathrm{F}_{2}$ segregated in $\mathrm{F}_{3}$ for $\mathrm{Bl}$ and three bred true. One oxblood red bred true as did three testaceous.

The color of China Red, then, is due to the presence of $R$. This variety may carry $R k$ (table 12) or $r k$ (table 13). In all crosses there was segregation for the purple gene $B l$, the dominant allelomorph coming from Red Kidney. Only one strain of China Red has been used in the crosses but the results found here prove that within the variety there are at least two genotypes. Since the presence of $R k$ does not alter the color of the bean, this genetic variation in the variety cannot be detected by examination of the beans themselves.

\section{CHINA RED $\times$ GENEVA RED KIDNEY}

The $F_{1}$ and $F_{2}$ data from this cross are given in table 14. The Geneva Red Kidney is a testaceous segregate from the cross White Kidney $X$ Red Kidney made by Gloyer (5). A summary of his results regarding color segregation was given in table 8 . Owing to its origin, this variety may carry brown modifiers, at least $c$, and probably others which could 


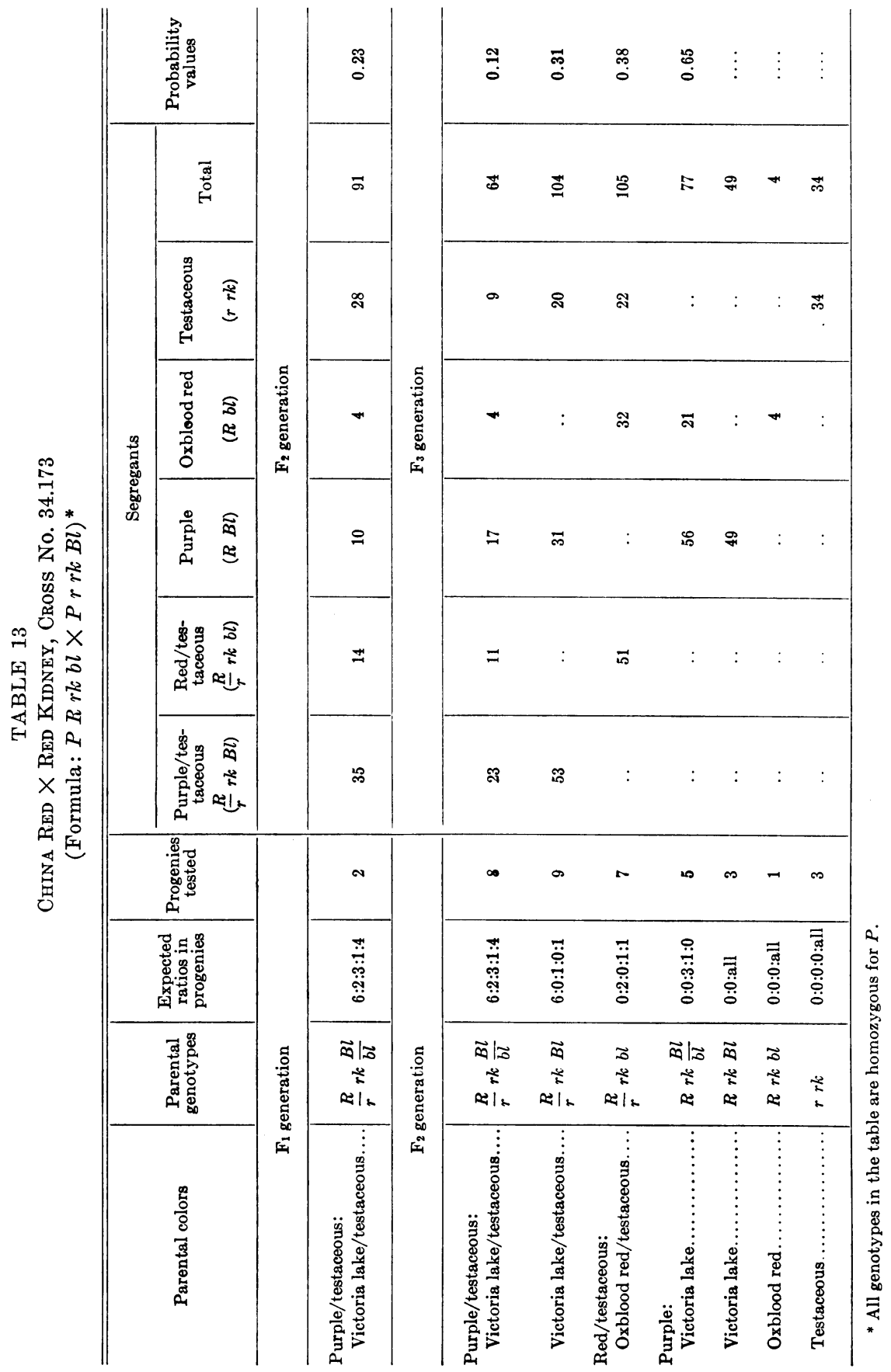




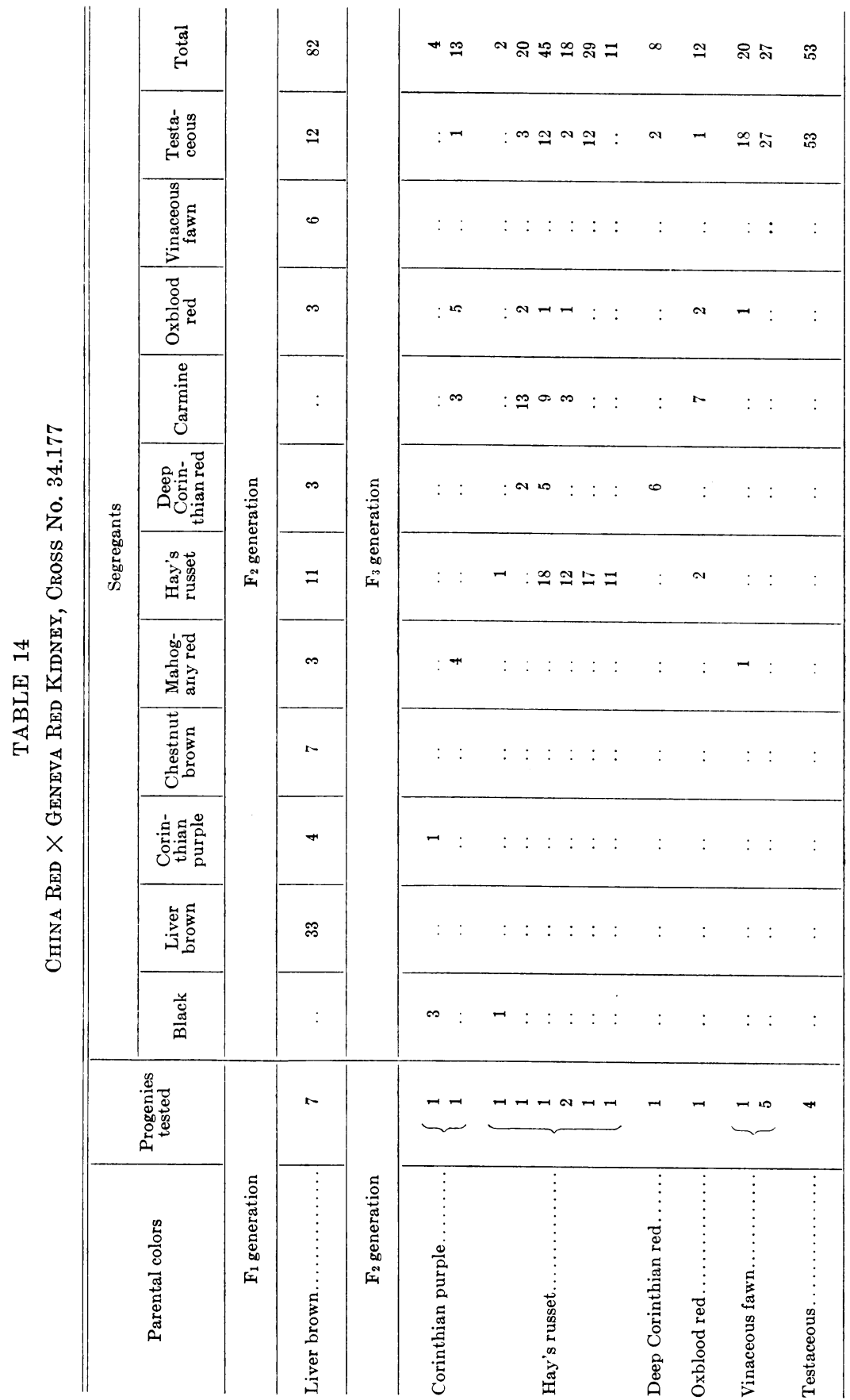


very likely give different results from those obtained with other Red Kidney beans.

The $\mathrm{F}_{1}$ of this cross was not mottled so that neither the $R$ nor the $C$ genes were segregating. This is rather disconcerting because the presence of $R$ has been shown to be the reason for the oxblood red color in the China Red variety in crosses with other strains of Red Kidney. This cross was different in other respects as well. In the $\mathrm{F}_{2}$ population of 82 plants, nine colors were recognized : Corinthian purple (plate 2, fig. 46) ; liver brown (plate 2, fig. 47) ; chestnut-brown (plate 2, fig. 48); mahogany red; Hay's russet (plate 2, fig. 49) deep Corinthian red (plate 2 , fig. 50) ; oxblood red (plate 2, fig. 51) ; vinaceous-fawn (plate 2, fig. 52 ) ; and testaceous (plate 2, fig. 53). The occurrence of liver brown and Corinthian purple indicates that $B l$ is segregating ; similarly the brown segregates indicates the presence of some brown color modifiers. Oxblood red was reclaimed only three times in the population, hinting that its expression is due to a double recessive condition of two genes; the number expected for a 15:1 ratio in a population of 82 is 5.1. Only one oxblood red was tested in $\mathrm{F}_{3}$. This one did not breed true as expected on the above hypothesis. It segregated 1 Hay's russet and 1 testaceous in a population of 12 .

The vinaceous-fawn color was proved to be a variation of testaceous because $\mathrm{F}_{3}$ progenies from this color all bred true for testaceous except one which had 1 oxblood red and 1 mahogany red plant in a population of 20. This could be explained as a natural outcross in the $\mathrm{F}_{2}$ generation. The vinaceous-fawn and testaceous colors, then, can be combined in $\mathrm{F}_{2}$, giving a total of 18 plants. This is about one-fourth of the population. The number expected on a $3: 1$ ratio is 20.5 ; this fits the expected ratio with a probability value of 0.53 .

Hay's russet showed in the $\mathrm{F}_{3}$ tests that it may segregate both oxblood red and testaceous colors. It, therefore, carries brown modifiers which are able to alter the colors in red beans.

It is interesting to note that seven of the ten $\mathrm{F}_{3}$ progeny rows tested, segregated testaceous. The number of testaceous plants segregated in these seven progenies was 33 in a total population of 145 . When these data are fitted to a $3: 1$ ratio the probability value is 0.54 .

\section{DARK RED KIDNEY $\times$ RED KIDNEY}

(Formula: $P R R k B l \times P r r k b l$ )

This cross segregated like the crosses involving China Red. Dark Red Kidney is reddish purple classed as Indian purple (plate 1, fig. 4). It should therefore carry $\mathbf{B l}$. Since this cross segregated purple and red 


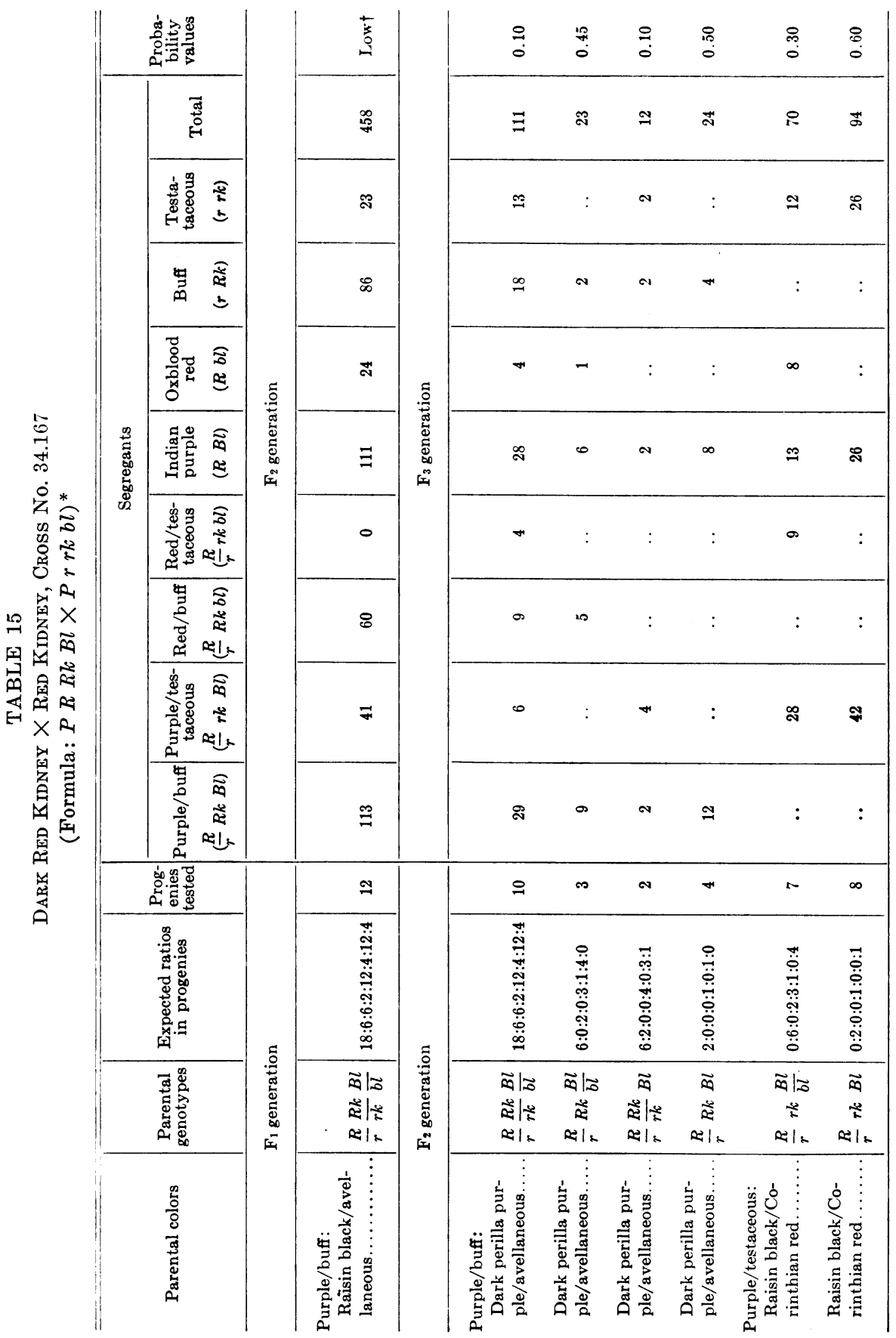




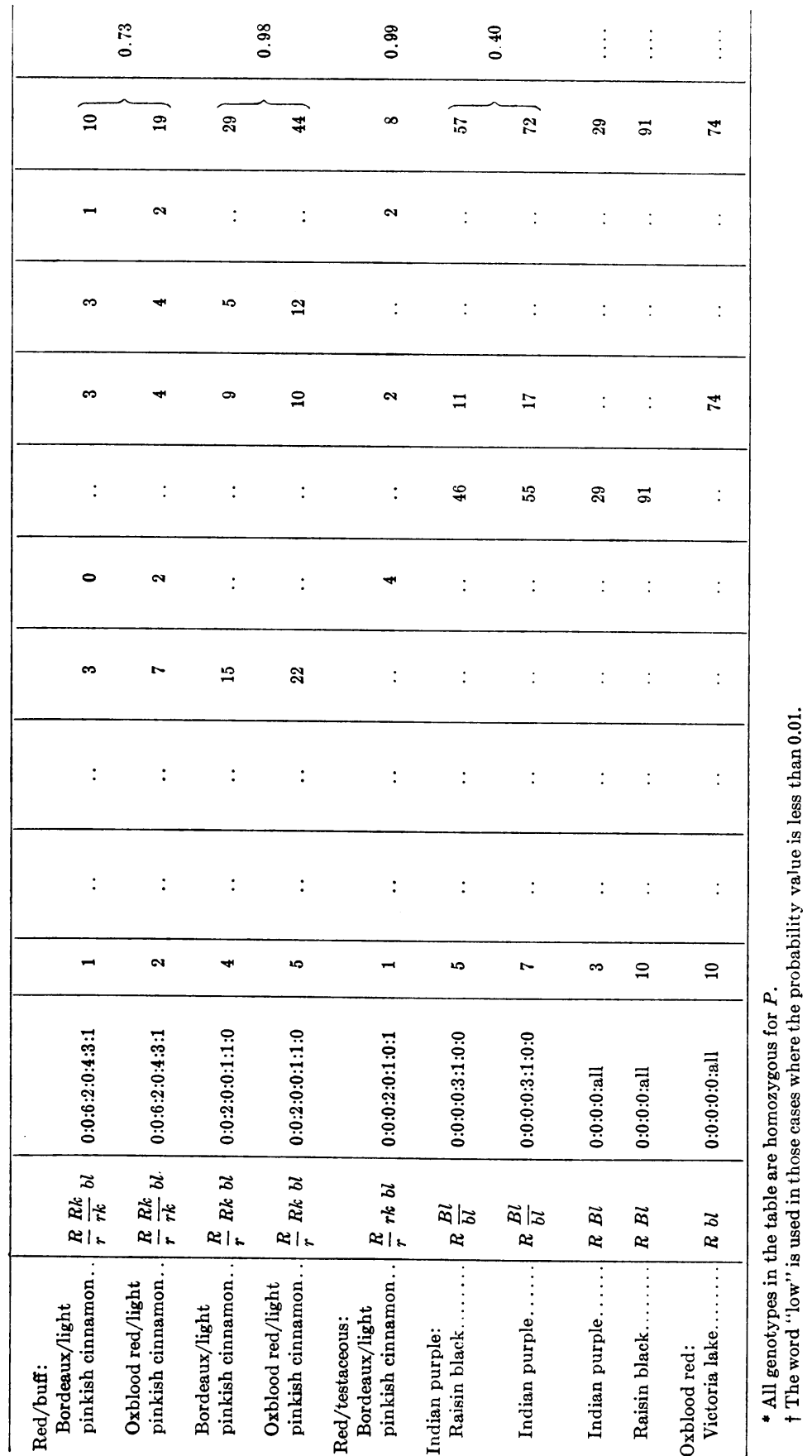


self-colored beans it must be assumed that $b l$ came from Red Kidney. The segregation of $B l$ is somewhat surprising because in all other crosses involving Red Kidney $\mathrm{Bl}$ is present. The results of this cross are summarized in table 15. In $F_{2}$ purple/buff was described as raisin black/ avellaneous and in $\mathrm{F}_{3}$ as raisin black/light pinkish cinnamon (plate 1, fig. 26). The purple/testaceous class was described as raisin black/Corinthian red in $\mathrm{F}_{2}$ and as Indian purple/testaceous in $\mathrm{F}_{3}$ (plate 1, fig. 13). The red/buff phenotype was divided into Bordeaux/light pinkish cinnamon and oxblood red/light pinkish cinnamon; in $\mathrm{F}_{3}$ they were all described as oxblood red/light pinkish cinnamon (plate 1, fig. 21). No red/testaceous beans were recognized in the $\mathrm{F}_{2}$; in $\mathrm{F}_{3}$, they were labeled oxblood red/testaceous (plate 1, fig. 27). The purple phenotype included raisin black and Indian purple in $\mathrm{F}_{2}$, dull violet-black (plate 1, fig. 23), and Indian purple (plate 1, fig. 29). The red beans were described as Victoria lake in $\mathrm{F}_{2}$ and as oxblood red (plate 1, fig. 25) in $\mathrm{F}_{3}$. Buff was called light pinkish cinnamon in $\mathrm{F}_{2}$ and pinkish cinnamon (plate 1 , fig. 7) in $\mathrm{F}_{3}$. The testaceous (plate 1, fig. 1) phenotype was called by that color name in both $\mathrm{F}_{2}$ and $\mathrm{F}_{3}$ generations.

The $\mathrm{F}_{2}$ population of 458 plants gave a poor fit for the expected ratio. This was because of the fact that one phenotype, red/testaceous, was not recognized. This was clearly an error in classification because one of the thirteen red/buff $\mathrm{F}_{2}$ plants subjected to $\mathrm{F}_{3}$ progeny test proved to be a red/testaceous genotype. In the purple/buff $\mathrm{F}_{2}$ plants grown in $\mathrm{F}_{3}$ ten segregated for $R, R k$, and $B l$; three for $R$ and $B l$; two for $R$ and $R k$; and four for $R$ only. Fifteen purple/testaceous $\mathrm{F}_{2}$ plants were tested. Seven segregated for $R$ and $B l$, and eight for $R$ only. Twelve red/buff plants were grown in $\mathrm{F}_{3}$. Three segregated for $R$ and $R k$ and nine for $R$ only. The single red/testaceous plant tested in $\mathrm{F}_{3}$ was classed as a red/ buff in $\mathrm{F}_{2}$; it segregated for $R$.

In the purple phenotypes two shades of purple were distinguished in $F_{2}$, raisin black and Indian purple. In breeding behavior these were identical. Five raisin black $\mathrm{F}_{3}$ progenies segregated for $\mathrm{Bl}$ and ten bred true; seven Indian purple progenies segregated for $B l$ and three bred true. The oxblood red group was called Victoria lake in $\mathrm{F}_{2}$; however, in $\mathrm{F}_{3}$ ten progenies bred true for oxblood red. No buff or testaceous $\mathrm{F}_{2}$ plants were grown in $\mathrm{F}_{3}$.

\section{IONG ROMAN X CHINA RED, AND RECIPROCAL}

(Formulas: $P M R R k b l \times P m R R k b l$ and $P m R R k b l \times P M R R k b l$ )

In the cross, Red Kidney $\times$ Long Roman (table 3 ) the red/buff Long Roman (plate 1, fig. 3) was found to be of the genetic constitution $P M$ 


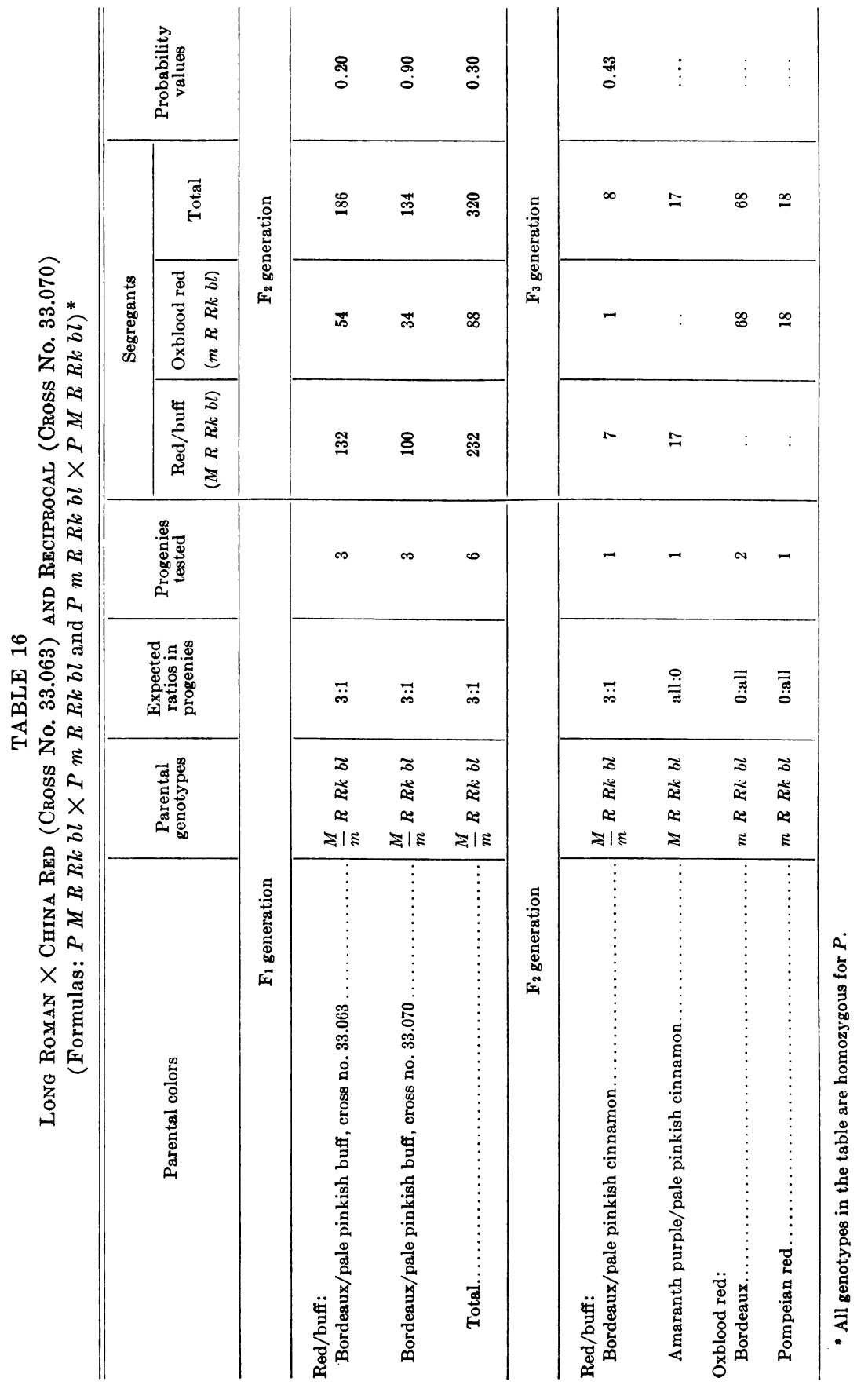


$R k b l$. The China Red has been found to be $P R R k b l$ (table 12) and $P R r k b l$ (table 13). Since genes for two types of mottling, $R r$ and $M$, have been shown in these two varieties it was hoped that an interaction of the two could be seen in this cross. In that case the $F_{1}$ should show double mottling and the $\mathrm{F}_{2}$ should segregate into 6 double mottled $\operatorname{Rr} M$ : 2 mottled $R r: 6$ mottled $M: 2$ self-colored $r m$ and $R m$.

However, in this reciprocal cross shown in table 16, the $\mathrm{F}_{1}$ was red/ buff and in $\mathrm{F}_{2}$ there was segregation for mottled and self-colored oxblood red in the ratio of $3: 1$, with a probability value of 0.30 , for a population of 320 . On the basis of a $3: 1$ ratio there should be 80 reds. There were actually 88 so that a $14: 2$ ratio is very improbable.

As expected, there is no segregation for $B l$ since both varieties have been shown to be homozygous for $b l$.

In the $\mathrm{F}_{2}$, four colors were recognized: the red/buff phenotype was classified as Bordeaux/pale pinkish cinnamon and amaranth purple/ pale pinkish cinnamon; and the red phenotype was divided into Bordeaux and Pompeian red. In the $\mathrm{F}_{3}$ progeny tests there was overlapping of the colors so that in table 16 they are grouped in only two classes, $\mathrm{red} / \mathrm{buff}$ and red.

Only four $\mathrm{F}_{2}$ plants were grown in $\mathrm{F}_{3}$. One red/buff segregated for $M$ and one bred true. Both oxblood reds bred true.

Since no testaceous phenotypes arose in this cross both varieties must have been homozygous for $R k$; and since no purple plants were found they were both homozygous for $b l$. The genotype of the China Red may then be written, $P m R R k b l$; and for Long Roman, $P M R R k b l$. The presence of $R$ in Long Roman, however, was not detected in crosses with Red Kidney (table 3). The poor fit to expectation in the crosses reported there, however, was due to misfits of two mottled classes red/buff and red/testaceous. Segregation for $M$ was 256 mottled : 78 self-colored; expected, $250.5: 83.5$. Had $R$ been segregating simultaneously, the ratio of mottled to self-colored should have been $292.25: 41.75$. It seems probable that the red mottling is due to the interaction of $M$ and $R$. To explain all the facts presented here $M$ and $R$ would have to be linked. Such a linkage of $M$ and $R$ offers a workable hypothesis as to the nature of the red in red-mottled beans. In the previous crosses the cause of the red mottling was not discussed; $M$ was considered to be a gene which restricts the expression of the darker color in bicolored beans, and it has been shown to be independent of $R k$ and $B l$. If $M$ and $R$ were linked, the following color types would be expected: purple/buff would be $P M R$ $R k B l$ or $P \frac{m R}{m r} R k B l$; purple/testaceous, $P M R r k B l$ or $P \frac{m R}{m r} r k B l$; 
red/buff, $P M R R k b l$ or $P \frac{m R}{m r} R k b l$; red/testaceous, $P M R r k b l$ or $P \frac{m R}{m r} r k b l$; purple, $P m R R k B l$ or $P m R r k B l$; oxblood red, $P m R$ $R k b l$ or $P m R r k b l$. Thus the oxblood red color in both self-colored and red-mottled beans could be due to the same gene, $R$. If there is a linkage between $M$ and $R$ it must be very strong because no cross-overs have been noted. The crosses reported in tables 1,2 , and 3 are between red/buff mottled beans and Red Kidney. Assuming linkage, these crosses may be represented as $P M R R k b l \times P m r r k B l$; the $F_{1}$ would be $\frac{P}{P} \frac{M R}{m r} \frac{R k}{r k} \frac{b l}{B l}$. The cross-over classes would be $m R$ and $M r$; of these, the $m R$ cross-overs should be easily identified as self-colored oxblood red, $P m R b l$, or self-colored purple, $P m R B l$. Since none of these appeared in any of these crosses, the crossing-over would have to be very small, if any. This argument is faulty for the same reason that Emerson's (3) $Y Z$ mottling theory was. Tjebbes (24) found close linkage between a red gene $R$ and a striping gene $S$ which occurs in the Cranberry variety. His red gene is not the same as the one encountered here because when heterozygous it does not produce mottling. It is probable, also, that $M$ and $S$ are not identical. It seems to be a strange coincidence that two red genes should each be linked with a mottling gene. More critical data are needed to study the interaction of $M$ and $R$.

\section{CHINA RED $\times$ MEXICAN RED, AND RECIPROCAL}

Both these varieties are dark red, matching Ridgway's (18) oxblood red very closely. Mexican Red, however, has a black hilum ring. The $\mathrm{F}_{1}$ was slightly darker than either parent and was classed as Victoria lake although it was more purple than this color. The hilum ring was black. In $F_{2}, 52$ mottled beans were found in a population of 364 . These mottled ones were not recognized until some mottled beans appeared in $\mathrm{F}_{3}$. The remnant $\mathrm{F}_{2}$ seed was then reëxamined and the $\mathrm{F}_{2}$ results given in table 17 are based on the second examination. It is possible therefore that some $\mathrm{F}_{2}$ seed which were grown in $\mathrm{F}_{3}$, although described as selfcolored, were actually mottled. Unfortunately no remnant seed was available for those $\mathrm{F}_{2}$ plants submitted to progeny tests. As is indicated in table 17 some mottled beans appeared in $\mathrm{F}_{3}$ from all three colors tested. From Victoria lake, two progenies out of eighteen tested segregated 5 mottled and 26 self-colored; from oxblood red three progenies out of twenty-five segregated 11 mottled and 37 self-colored; and from Vandyke red five progenies out of twenty-seven tested segregated 25 
[VoL. 12, No. 9

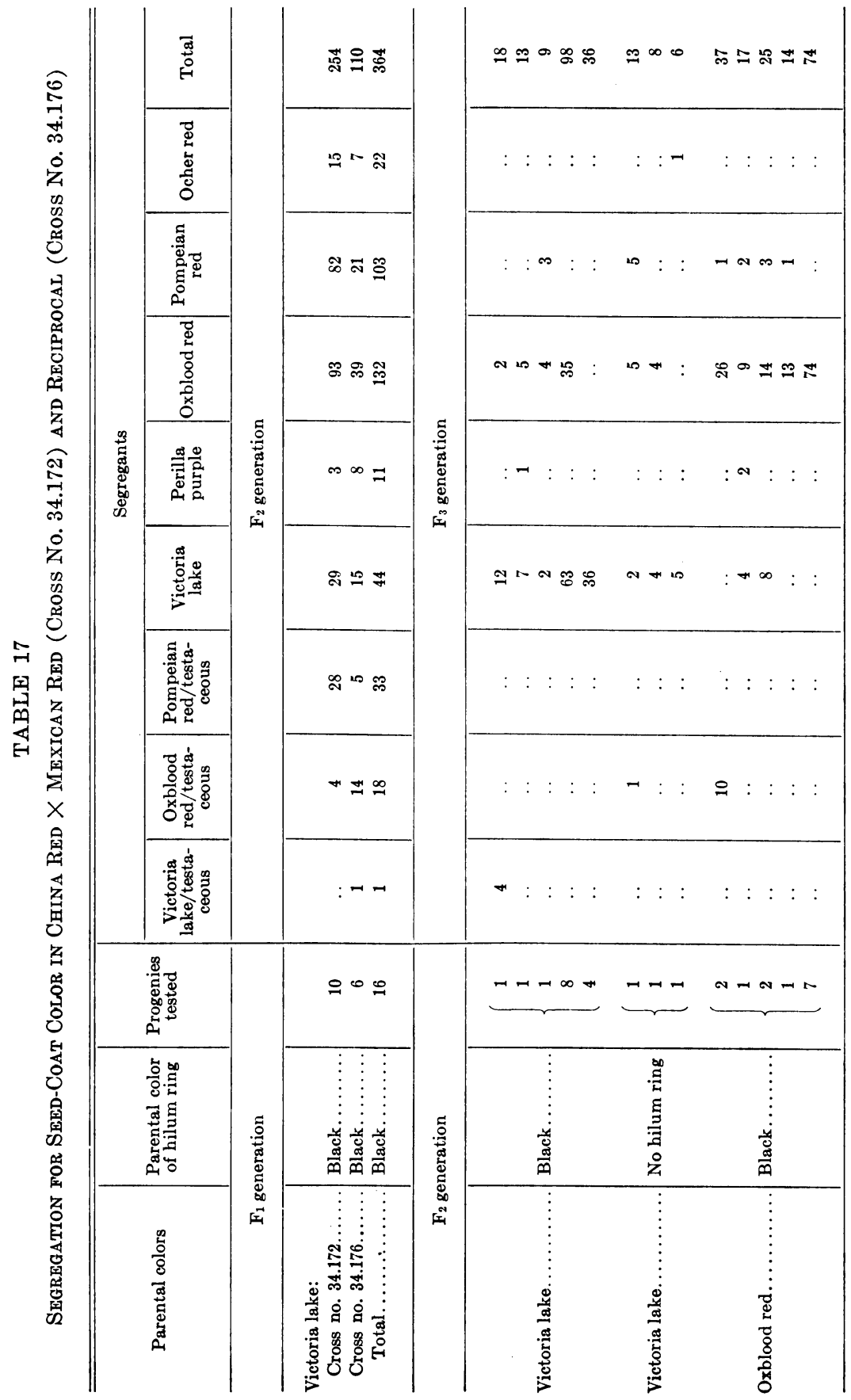




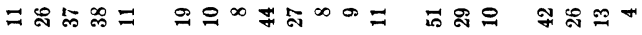

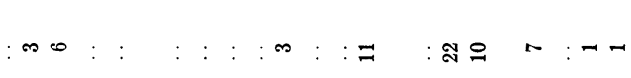

ヘ๓ை上:

๓ ニ

ก๓: :

$\neg: \quad: \quad: \quad \infty \quad \infty \quad \infty \quad: \quad: \quad: \quad: \quad: \quad: \quad: \quad:$

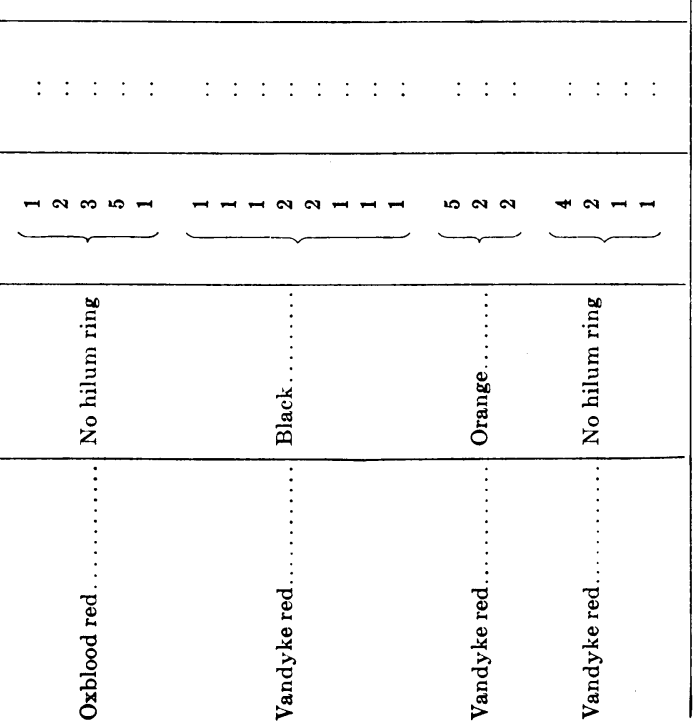


mottled and 73 self-colored. It is thus apparent the segregation of mottled and self-colored beans in this hybrid is not constant. If the mottling were due to the action of the $R$ gene, the self-colored beans should breed true unless some modifying factors prevented the expression of mottling. The mottled types should segregate mottled and self-colored plants in the ratio of $1: 1$.

The only available data on this question are the results from progeny tests of two $\mathrm{F}_{3}$ mottled plants. These segregated 10 mottled and 11 selfcolored. This information though meager bears out the assumption that the reactions of the $R$ gene were obscured in $\mathrm{F}_{1}$ and partially in $\mathrm{F}_{2}$ by modifying genes and it was not until these were eliminated in $F_{3}$ that clear-cut segregation for $R$ could be detected.

The segregation of color of the seed coat in this cross is almost as baffling. The shades of red obtained in the $\mathrm{F}_{2}$ and $\mathrm{F}_{3}$ were so numerous and gradual that separation into modal classes was difficult. It is certain, however, that no testaceous beans were obtained in any of the $\mathrm{F}_{2}$ or $\mathrm{F}_{3}$ populations. Since China Red has been shown to carry $R k$ (table 12) and $r k$ (table 13), and since no testaceous $r k$ types appeared in this cross, both parents must have been homozygous for the $R k$ gene. It must be assumed, however, that the presence of other modifying genes prevented the buff $R k$ types from appearing because no buff beans were found in any of the offspring from this cross.

The presence of a colored hilum ring is a difficult character to study because not all beans from a single plant show the hilum ring color. It is therefore very easy to make errors in classification. Furthermore, the color of the hilum ring depends largely on the color of the seed coat. This is demonstrated in the $\mathrm{F}_{2}$ data. The beans were classed as Victoria lake, perilla purple, oxblood red, Pompeian red, and ocher red. There were 44 plants with Victoria lake seed-coat color, 36 with black hilum ring, 1 with orange ring, and 7 with no ring. All 11 of the plants with perilla purple seed coats had black hilum ring. The oxblood red plants numbered 132 of which 89 had black ring, 15 had orange, and 28 had no ring. The 132 Pompeian red plants were classed as 72 with black hilum ring, 18 with orange, and 13 with no ring. In 22 ocher-red plants, 11 had black hilum ring, and 11 had orange. Segregation for hilum-ring character in this cross is shown in table 18. Some progenies bred true for both black and orange hilum ring but no true-breeding progenies with no hilum ring were obtained. Some of the $\mathrm{F}_{2}$ plants classed as having no hilum ring proved in progeny tests to have rings. The character for orange hilum ring bred true in two progenies of oxblood red and two of Vandyke red. Black ring seems to be dominant over orange but there 
are cases of $\mathrm{F}_{2}$ plants with orange ring segregating plants with black rings. The genetic nature of the hilum ring character therefore is difficult to understand.

TABLE 18

Segregation for Hilum-Ring Color in China Red $\times$ Mexican Red (Cross No. 34.172) AND RECIPROCAL (Cross No. 34.176)

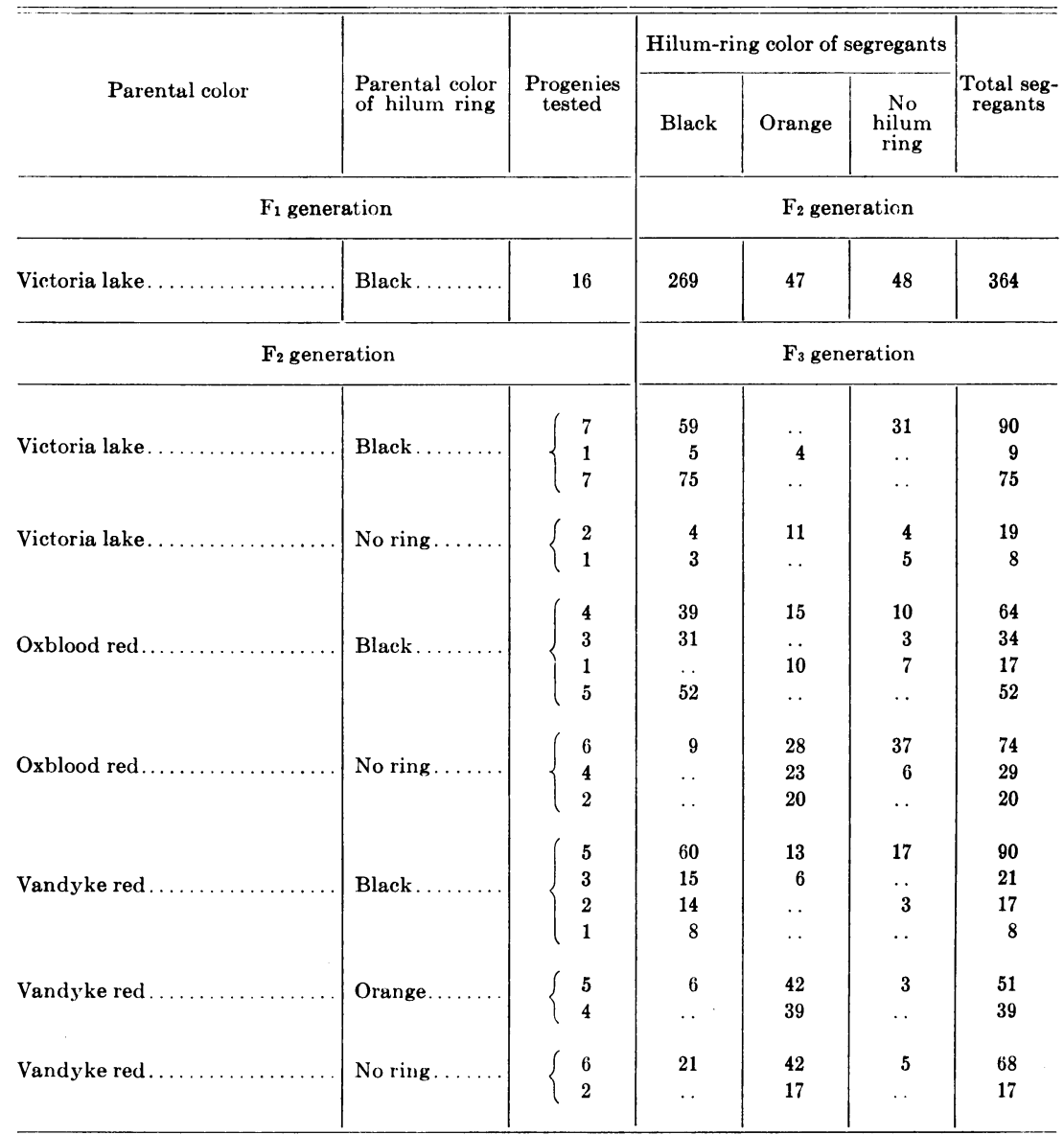

\section{MEXICAN RED $\times$ RED KIDNEY}

The results from this cross are summarized in table 19 . The $\mathrm{F}_{1}$ was violet carmine. The names given to the color classes varied somewhat between the $\mathrm{F}_{2}$ and $\mathrm{F}_{3}$ generations. The relation between them was as follows: Beans which were classified as dull purplish black in $\mathrm{F}_{2}$ were black and Indian purple in $\mathrm{F}_{3}$; Victoria lake was used in both generations; in $\mathrm{F}_{2}$ 


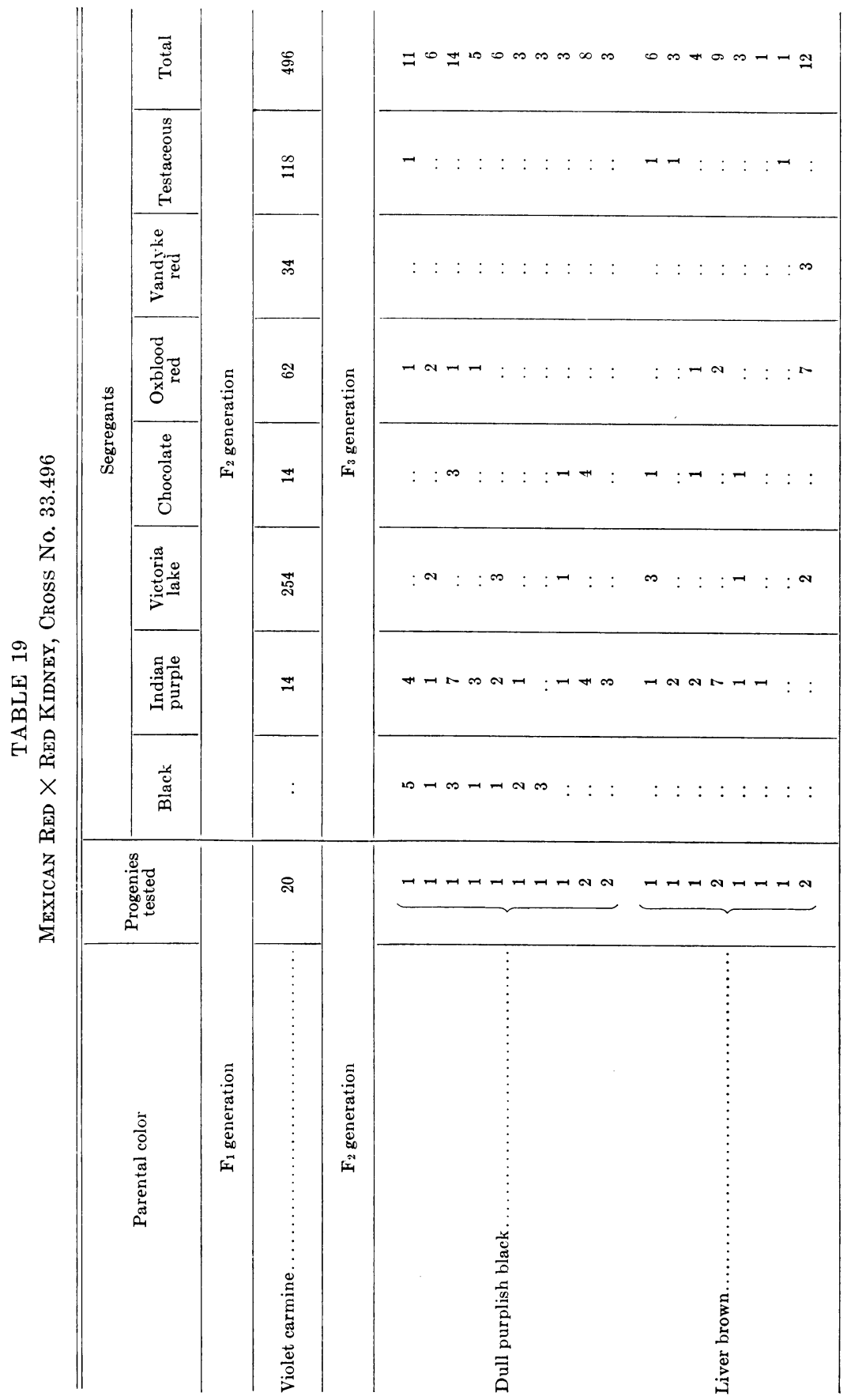




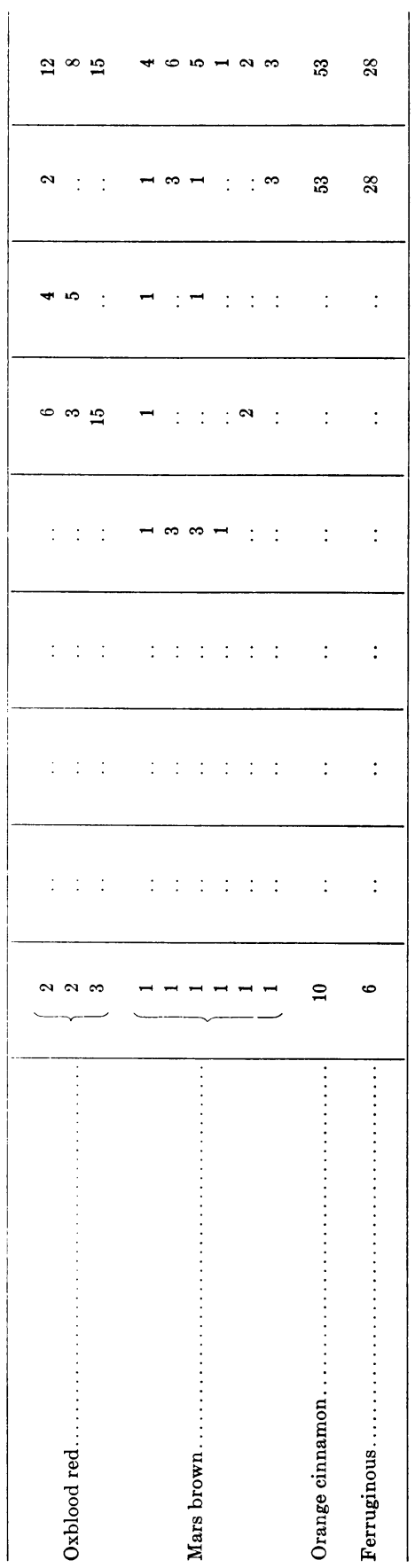


liver brown and burnt umber were grouped together as chocolate in $\mathrm{F}_{3}$; oxblood red was used in both generations; beans classed as Pompeian red in $\mathrm{F}_{2}$ were called Vandyke red in $\mathrm{F}_{3}$. A number of light-red types similar to testaceous were distinguished in $\mathrm{F}_{2}$ but all proved to be testaceous when submitted to progeny tests. These $\mathrm{F}_{2}$ color names, then, can all be grouped together : orange-cinnamon, Japan rose, ferruginous, and testaceous. $\mathrm{F}_{3}$ progeny tests were made of a number of $\mathrm{F}_{2}$ plants but owing to poor stand in the nursery, the $\mathrm{F}_{3}$ populations were too small to obtain accurate ratios.

Although the colors do not segregate in definable ratios a number of illuminating facts are observed. The colors obtained in this cross are illustrated in plate 2, figures 54-59. The $\mathrm{F}_{1}$ was purplish red (violet carmine) therefore the $B l$ gene was able to modify the color in this hybrid. It appears that each parent contributed some purple modifying genes because in $\mathrm{F}_{3}$ progenies from $\mathrm{F}_{2}$ Indian-purple plants (plate 2, figs. 6364 ), some beans appeared which could be described by no better word than black (plate 2, fig. 54). These may well be due to accumulation of darkening modifiers contributed from both parents. The light-red beans, such as Vandyke red (plate 2, fig. 58), may well be due to homozygous combinations of red genes with $b l$ and other recessive purple modifiers.

Another interesting fact noted in this cross is the absence of segregation of color of the hilum ring, presumably due to the fact that both Red Kidney and Mexican Red have colored hilum rings; the ring in the former is orange and in the latter, black. On this basis, crosses between Red Kidney and China Red or Dark Red Kidney should have segregated for colored hilum ring. This, however, was not observed; but no special attention was paid to this character in those crosses.

Still another fact is apparent in the Mexican Red $\times$ Red Kidney cross. In the $\mathrm{F}_{2}$ population of 496 plants, there were 118 testaceous plants (table 19). Fitted to a $3: 1$ ratio there should have been 124 ; the probability value for such a fit is 0.54 . In the $F_{3}$ progenies there were 7 which segregated 10 testaceous plants in a population of 47 . The probability value for these results, fitting a $3: 1$ ratio, is 0.57 . Thus it is apparent that the recessive gene $r k$ is segregating normally in this cross. But what has become of $R k$ since no buff beans were found in any of the progenies? It is now apparent that Mexican Red either has a third allelomorph of the $R k r k$ gene pair or other color genes prevent its expression as buff.

Still another fact is apparent in this cross which should not be overlooked and that is the absence of mottled beans. Since some mottled beans were obtained in the China Red $\times$ Mexican Red cross the assump- 
tion was made that the $R$ gene was segregating. China Red is known to carry the dominant allelomorph $R$; so, if mottling were due to heterozygous $R$, Mexican Red must carry $r$. This fits in with the facts obtained in this cross. Red Kidney has been shown to carry $r$ and if Mexican Red does also, no mottled beans are expected in the progeny of this cross.

\section{MEXICAN RED $\times$ DARK RED KIDNEY}

The $\mathrm{F}_{1}$ of this cross was classed as Vandyke red with a black hilum ring. In $\mathrm{F}_{2}$ it segregated for the hilum-ring character. The results of the segregation for seed-coat color are given in table 20 and for the hilum ring character in table 21.

Regarding mottling, much the same result was obtained here as in the China Red $\times$ Mexican Red cross. The faint mottling was entirely overlooked in $\mathrm{F}_{2}$. When the $\mathrm{F}_{3}$ was obtained showing mottled beans, the $\mathrm{F}_{2}$ remnants were reëxamined and four mottled beans were found which had been previously classified as Corinthian purple. Two $\mathrm{F}_{2}$ progenies segregated such a high proportion of mottled offspring in $\mathrm{F}_{3}$ that they must have been mottled in $\mathrm{F}_{2}$. These two progenies, which are indicated in table 20, consisted of 42 plants of which 22 were mottled. For a 1:1 ratio there should have been 21 . Fitted to such a ratio the probability value is 0.76 . It is apparent that the $R$ gene is segregating in this cross but some modifying genes prevent the expression of mottling in some cases. Further proof for the presence of $R$ was obtained by subjecting known mottled $\mathrm{F}_{3}$ beans of this cross to progeny tests. From eight progenies 120 plants were harvested, 56 being mottled and 64 self-colored. These data fitted to a $1: 1$ ratio give a probability value of 0.47 .

Since some reddish purple (Indian purple, plate 2, figs. 63,64 ), and purple (perilla purple, plate 2 , fig. 65 ) beans were obtained, it is assumed that the color genes in Dark Red Kidney (Indian purple, plate 1, fig. 4) were responsible. No blacks, however, were found in the $\mathrm{F}_{3}$ so there was no accumulation of dark modifiers as in Mexican Red $\times$ Red Kidney. In the cross Dark Red Kidney $\times$ Red Kidney (table 15) evidence of segregation of $B l$ was obtained. Thus the $B l$ gene carried by Red Kidney is not the same gene as the purple modifier in Dark Red Kidney or black beans would have been obtained in the $\mathrm{F}_{3}$ of the cross Mexican Red $X$ Dark Red Kidney. Oxblood red was reclaimed often in the $\mathrm{F}_{2}$ of this cross and so was a still lighter red, classed as acajou red (plate 2, figs. $69,70)$. Acajou red is lighter in color than the Mexican Red parent and indicates that it may have fewer dominant color genes for red or purple than either parental variety. No testaceous beans were obtained in this cross indicating that neither parent carries $r k$. 
[Vol. 12, No. 9

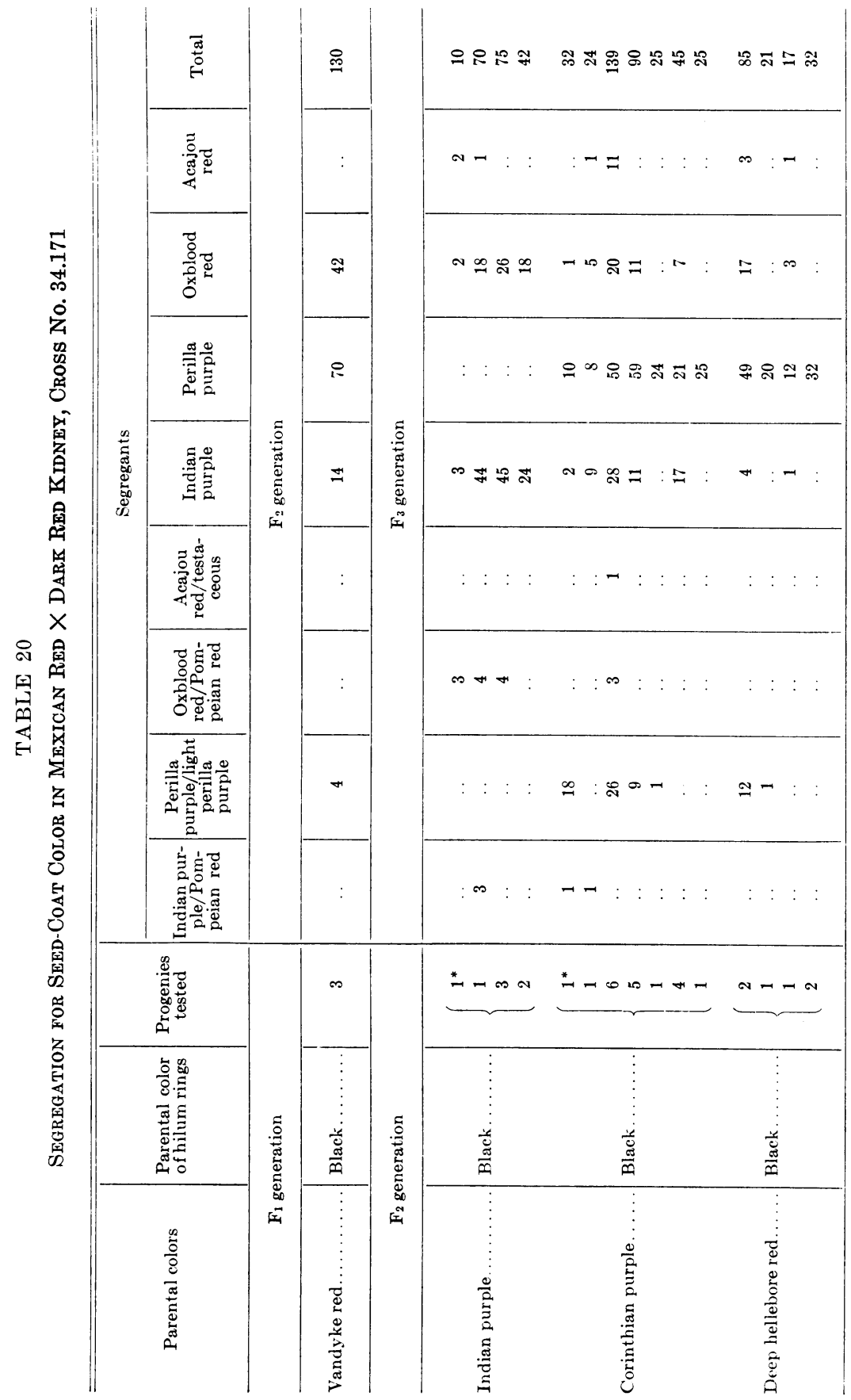




\begin{tabular}{|c|c|c|c|c|c|}
\hline లొ భ & ホี่ న̊ำ & 고 $\infty$ & 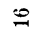 & 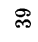 & $1 \mathscr{1} \cong \cong \Re$ \\
\hline-2 & $:: \infty 1-$ & จำ: & 10 & : & N : : : ه : \\
\hline ణొ ๓ & $0: 2$ & 윰둥 & $\infty$ & $\infty$ & $\forall \forall \infty \infty \Re$ \\
\hline$: \quad:$ & $\because 200$ & N : : & : & बू & $:: \infty:$ : \\
\hline$:$ : & $: \quad: \quad: \quad:$ & $: \quad: \quad:$ & : & r & ユエ : : : \\
\hline$:$ : & $::$ : : & $:::$ & : & : & $:::::$ : \\
\hline$\sim$ : & $:::$ : & $:::$ & : & : & $:::::$ : \\
\hline$: \quad:$ & $\infty 1:$ : & $: \quad: \quad:$ & : & : & $: \quad: \quad: \quad: \quad:$ \\
\hline$:$ : & $::: \quad:$ & $: \quad: \quad:$ & : & : & $:::: \quad:$ \\
\hline$\neg \sim$ & $N-T-1$ & NN & N & - & $\leadsto$ ガー \\
\hline$\frac{\dot{y}}{\frac{\tilde{m}}{m}}$ & 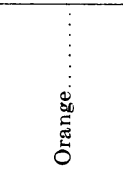 & 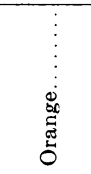 & 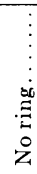 & 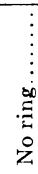 & $\begin{array}{l}\dot{\infty} 0 \\
\stackrel{\Xi}{\Xi} \\
\dot{0}\end{array}$ \\
\hline 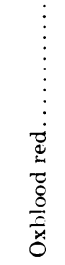 & 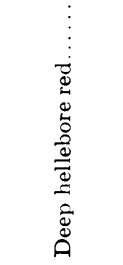 & 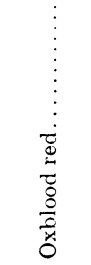 & 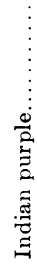 & 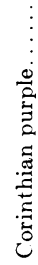 & 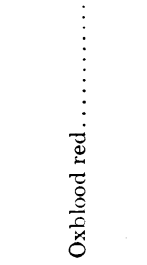 \\
\hline
\end{tabular}


In the study of the hilum-ring character, summarized in table 21, the same difficulties of clearly distinguishing the different phenotypes were encountered as described in the China Red $\times$ Mexican Red. Here there was further evidence that the color of the hilum ring and the color of the seed coat are associated. This condition has already been noted in the literature $(12,17)$. In the $\mathrm{F}_{2}$ generation the Indian-purple progeny

TABLE 21

Segregation for Hilum-Ring Color in Mexican Red $\times$ Dark Red Kidney, Cross No. 34.171

\begin{tabular}{|c|c|c|c|c|c|c|}
\hline \multirow[b]{2}{*}{ Parental color } & \multirow{2}{*}{$\begin{array}{l}\text { Parental color } \\
\text { of hilum ring }\end{array}$} & \multirow[b]{2}{*}{$\begin{array}{l}\text { Progenies } \\
\text { tested }\end{array}$} & \multicolumn{3}{|c|}{ Hilum-ring color of segregants } & \multirow[b]{2}{*}{$\begin{array}{l}\text { Total seg- } \\
\text { regants }\end{array}$} \\
\hline & & & Black & Orange & $\underset{\text { hilum }}{\text { No }}$ & \\
\hline \multicolumn{3}{|c|}{$F_{1}$ generation } & \multicolumn{4}{|c|}{$F_{2}$ generation } \\
\hline Vandyke red.... & Black... & 3 & $\$ 2$ & 20 & 28 & 130 \\
\hline \multicolumn{3}{|c|}{$F_{2}$ generation } & \multicolumn{4}{|c|}{$F_{3}$ generation } \\
\hline Indian purple. . & Black. & 7 & 93 & 39 & 65 & 197 \\
\hline \multirow{4}{*}{ Corinthian purple. } & \multirow{4}{*}{ Black. } & 9 & 122 & 42 & 33 & 197 \\
\hline & & 8 & 114 & 31 & . & 145 \\
\hline & & 1 & 11 & . & 2 & 13 \\
\hline & & 1 & 25 & . & . & 25 \\
\hline \multirow{3}{*}{ Deep hellebore red. . } & \multirow{3}{*}{ Black. } & 2 & 54 & 26 & 5 & 85 \\
\hline & & 3 & 35 & 14 & . & 49 \\
\hline & & 1 & 21 & . & . & 21 \\
\hline Oxblood red.. & Black. & 3 & E3 & 16 & 12 & 81 \\
\hline \multirow[t]{2}{*}{ Deep hellebore red. } & \multirow[t]{2}{*}{ Orange........ } & $\{2$ & . & 47 & 4 & 51 \\
\hline & & 3 & . & 41 & . & 41 \\
\hline \multirow{4}{*}{ Oxblood red.. } & \multirow{4}{*}{ Orange $\ldots . . .}$. & 2 & 7 & 45 & 8 & 60 \\
\hline & & 1 & 1 & 2 & . & 3 \\
\hline & & 3 & . & 37 & 12 & 49 \\
\hline & & 4 & . & 41 & . & 41 \\
\hline \multirow{2}{*}{ Indian purple.. } & \multirow{2}{*}{ No hilum ring } & 1 & . & .. & 1 & 1 \\
\hline & & 1 & $\cdots$ & 1 & 14 & 15 \\
\hline Corinthian purple...... & No hilum ring & 1 & 9 & 16 & 14 & 39 \\
\hline \multirow{4}{*}{ Oxblood red.. } & \multirow{4}{*}{ No hilum ring } & 1 & 2 & 2 & 8 & 12 \\
\hline & & 4 & .. & 17 & 21 & 38 \\
\hline & & 2 & . & 14 & & 14 \\
\hline & & 2 & . & . & 27 & 27 \\
\hline
\end{tabular}


were classed as 10 with black hilum ring and 4 with no ring; in the perilla purple, 59 had black hilum ring, 9 had orange, and 1 no ring; in the oxblood red, 9 had black hilum ring, 11 had orange, and 22 no ring; in the perilla purple/light perilla purple all 4 had black hilum rings.

The plants with black hilum rings seem to be able to segregate both orange rings and no rings as well as breed true. Orange hilum ring usually breeds true or segregates no ring but occasionally some progeny with black ring come from $\mathrm{F}_{2}$ plants with orange hilum ring. $\mathrm{F}_{2}$ plants classed as having no rings did not always breed true-in fact most of them reverted to orange rings or in a few cases black. Two $\mathrm{F}_{3}$ progenies from oxblood with no hilum ring bred true in $\mathrm{F}_{3}$.

As can be seen in table 20 there is some discrepancy in the color description of $\mathrm{F}_{2}$ and $\mathrm{F}_{3}$. The two colors, Corinthian purple and deep hellebore red recognized in $F_{2}$ were grouped together in $F_{3}$ as perilla purple.

\section{NATURE OF THE COLOR COMPLEX IN MEXICAN RED}

In the three crosses just discussed no attempt was made to give the genetic formula of Mexican Red. We can, however, make some assumptions which are based on the results of the crosses involving this variety.

Both China Red and Dark Red Kidney carry $R$ and since some mottled beans were found in $F_{2}$ and $F_{3}$, when these varieties were used in crosses with Mexican Red, the mottling was attributed to the action of $R . \mathrm{F}_{4}$ data from both China Red $\times$ Mexican Red and Mexican Red $\times$ Dark Red Kidney crosses were presented to show that mottled hybrid beans do segregate in the ratio of 1 mottled to 1 self-colored as expected. This was explained on the basis that the reactions of $R$ were obscured by interactions of other color genes but when these modifiers were eliminated in the $\mathrm{F}_{3}$ the action of $R$ could be readily seen. Thus Mexican Red carries $r$. Since Red Kidney also carries $r$ there should be no mottling in the progeny of a cross between these varieties. Since none were found this is further evidence that Mexican Red must carry $r$.

Some $\mathrm{F}_{3}$ beans were obtained in these crosses which were darker than either parent, a fact explained by assuming that the Mexican Red carries purple modifiers as well as the other varieties and the dark colors are due to accumulation of these modifiers in homozygous condition in some genotypes. The reverse situation was also observed. Some $\mathrm{F}_{3}$ beans were lighter red than either parent indicating the elimination of the dominant purple modifiers. The genetic nature of the colored hilum ring has not been settled in this work. Because it is difficult to always distin- 
guish this character, errors are easily made in classification. After they have been made it is hard to reconcile the notes on the hybrids in the succeeding generation. There is some evidence that the color of the ring is associated with the color of the seed coat but there are also enough exceptions to make a general rule untenable.

Mexican Red was shown in crosses with Red Kidney to carry a dominant allelomorph of $r k$ since one-fourth of the $\mathrm{F}_{2}$ and segregating $\mathrm{F}_{3}$ progenies were testaceous. China Red and Dark Red Kidney have been shown to carry $R k$ a dominant allel of $r k$ which makes beans buff in color in the absence of the dominant red gene $R$. Now, since Mexican Red does not carry $R$, and since no buff beans were found in any of the crosses, it must carry other red color genes which prevent $R k$ from appearing as buff. Another explanation, advanced earlier in the paper is that this variety may carry a third allel in the $R k r k$ series. No critical data are available to make a choice between these two possibilities.

Crosses involving Mexican Red were the most difficult to analyze genetically but the hybrids show more promise as a foundation for a breeding program to improve the color of Red Kidney than any other variety tested. The new light-red colors which may be useful are : Pompeian red (plate 2, fig. 44), and ocher red (plate 2, fig. 45) from the cross China Red $\times$ Mexican Red; Vandyke red (plate 2, fig. 58) from the cross Mexican Red $\times$ Red Kidney; and acajou red (plate 2, figs. 69, 70) from the cross Mexican Red $\times$ Dark Red Kidney. Whether these reds will prove useful to this end remains to be seen in later breeding work.

\section{SUMMARY}

Hybrids between red-seeded varieties of common beans were made to study the genetic nature of red. Ridgway's (18) color nomenclature was used in the descriptions. The results of this study are applicable in improvement of the Red Kidney variety, which changes in time from red to brown or tan while in storage or when in sunlight. Six genes were encountered which affect seed-coat color or its distribution.

$P$ is a primary pigmentation factor necessary for any color to develop. Beans with $P$ but without any complementary pigmentation color genes are white. All the bean varieties studied carried one or more complementary color factors. Beans homozygous for $p$ are white regardless of the color genes they may have.

$M$ is a mottling gene which was found in a number of red-mottled varieties; its recessive allelomorph, $m$, is self-colored.

$R k$, a gene for buff color, is the dominant allelomorph of $r k$, which is responsible for the testaceous color typical of the Red Kidney variety. 
The interactions of $R k r k$ have not been known heretofore. $M R k$ beans are mottled on buff background, and $M r k$ are mottled on testaceous background.

$R$ is a gene for deep red (oxblood red). In the genotypes studied $R R k$ and $R r k$ were oxblood red; $r R k$, buff; and $r r k$, testaceous. Beans heterozygous for $R$ are mottled: those with $R r R k$ are mottled on buff background and those with $R r r k$ are mottled on testaceous.

$B l$ is a color modifier which changes oxblood red to purple. It also changes red-mottled beans to purple-mottled when the mottling is caused by either heterozygous $R$ or $M$.

$E$ is the dominant allelomorph of $e$, a gene for eye pattern. $E$ beans are self-colored. The eyed variety used was white with a red eye, the red being due to $r k$.

No linkage was found between $R k M B l, R k R B l$, or $R k E$. Linkage between these genes and $P$ could not be demonstrated because all $p$ genotypes are white. Some data were obtained indicating complete linkage of $M$ and $R$. No cross-over classes were found.

Not one of these genes was suitable as a color modifier of Red Kidney. However, $\mathrm{F}_{3}$ segregates were obtained in crosses involving Mexican Red which were nearer the ideal type. Further experiments are necessary to ascertain the practical value of these reds. The genotype of Mexican Red was not obtained because it carries a number of modifiers which made classification difficult. No buff segregates were found in crosses involving Mexican Red, although about one-fourth of the $\mathrm{F}_{2}$ population was testaceous in the cross Mexican Red $\times$ Red Kidney. Mexican Red either has modifiers which prevent the expression of buff or it carries a third allelomorph for the $R k r k$ gene pair. 


\section{LITERATURE CITED}

1. Emerson, R. A.

1904. Heredity in bean hybrids (Phaseolus vulgaris). Nebraska Agr. Exp. Sta. Seventeenth Ann. Rept. p. 33-68.

2. EMERSon, R. A.

1909. Factors for mottling in beans. Amer. Breeders Assoc. Ann. Rept. 5: 368-76.

3. EMerson, R. A.

1909. Inheritance of color in the seeds of the common bean, Phaseolus vulgaris. Nebraska Agr. Exp. Sta. Twenty-second Ann. Rept. p. 65-101.

4. Fisher, R. A.

1936. Statistical methods for research workers, 6th ed., 252 p. Oliver and Boyd, London.

5. GLOYER, W. O.

1928. Two new varieties of Red Kidney bean: Geneva and York. New York Agr. Exp. Sta. Tech. Bul. 145:1-51.

6. Koolman, H. N.

1920. Over de Erfelijkheid van de kleur der zaadhuid van Phaseolus vulgaris [On the heredity of the seed-coat color in Phaseolus vulgaris.] Academisch proefschrift, Utretcht Bussum, van Dishoeck : 98 p.

7. KoOIMaN, H. N.

1931. Monograph on the genetics of Phaseolus. Bibliographia Genetica 8:295413.

8. KRISTOFFERSON, K. B.

1924. Color inheritance in the seed coat of Phaseolus vulgaris. Hereditas 5: 33-43.

\section{LAMPRECHT, H.}

1932. Beiträge zur Genetik von Phaseolus vulgaris. I. Zur Vererbung der Testafarbe. Hereditas 16:169-211.

10. LAMPRECHT, H.

1932. Zur Genetik von Phaseolus vulgaris. III. Zweiter Beitrag zur Vererbung der Testafarbe. Hereditas 17:1-20.

11. LAMPRECHT, H.

1932. Zur Genetik von Phaseolus vulgaris. V. Spaltungsergebnisse nach Kreuzung einer weisssamigen mit gefärbtsamigen Bohnenlinien. Hereditas 17: $54-66$.

12. LAMPRECHT, H.

1933. Zur Genetik von Phaseolus vulgaris. VI. Vierter Beitrag zur Vererbung der Testafarbe. Hereditas 17:249-316.

13. LAMPRECHT, $\mathrm{H}$.

1934. Zur Genetik von Phaseolus vulgaris. VIII. Ưber Farbenverteilung und Vererbung der Teilfarbigkeit der Testa. Hereditas $19: 177-222$. 
14. LAMPRECHT, H.

1934. Zur Genetik von Phaseolus vulgaris. IX. Über den einfluss des Genpaares $R-r$ auf die Testafarbe. Hereditas 20:32-46.

15. MeNDel, G. J.

1866. Versuche über Pflanzen-hybriden. Verh. Naturf. Ver. in Brünn Abhandl. 4. English translation in: Bateson, W., Mendel's principles of heredity. p. 335-79. Cambridge University Press, London. 1930.

16. Miyake, K., Y. ImaI, and K. TABUChI

1930. Contributions to the geneties of Phaseolus vulgaris. Jour. College of Agr. Tokyo. 11:1-20.

17. Prakken, $\mathrm{R}$.

1934. Inheritance of colours and pod characters in Phaseolus vulgaris L. Genetica $16: 177-296$.

18. RIDGWAY, R.

1912. Color standards and color nomenclature. 43 p., 53 plates. Published by the author. Washington, D. C.

19. SAX, K.

1923. The association of size differences with seed-coat pattern and pigmentation in Phaseolus vulgaris. Geneties 8:552-60.

20. Shaw, J. K., and J. B. NoRTon

1918. The inheritance of seed-coat color in garden beans. Massachusetts Agr. Exp. Sta. Bul. 185:59-104.

21. SHull, G. H.

1907. Some latent characters of a white bean. Science n.s. 25:828-32.

22. SHULL, G. H.

1908. A new Mendelian ratio and several types of latency. Amer. Nat. 42: 433-51.

23. SURFACE, F. M.

1916. A note on the inheritance of eye pattern in beans and its relation to type of vine. Amer. Nat. 50:577-86.

24. TJEBBES, $\mathrm{K}$.

1931. Two linkage groups in the garden bean. Hereditas $15: 185-94$.

25. TJebbes, K., and H. N KooImaN

1921. Erfelijkheidsonderzoekingen bij boonen. IV. Over den streepings-factor. Een geval van volkomen afstooting tusschen twee factoren. [On the striping factor, a case of complete repulsion between two factors]. V. Analyse eener spontane kruising van de stokkievtsboon. [Analysis of a spontaneous cross of the Speckled Cranberry bean.] Genetica 3:28-49.

26. TSCHERMAK, E. vON

1901. Weitere Beiträge über Verschiedenwertigkeit der Merkmale bei Kreuzung von Erbsen und Bohnen. Ber. Deut. Bot. Gesell. 19:35-51. 
27. TSCHERMAK, E. voN

1901. Weitere Beiträge über Verschiedenwertigkeit der Merkmale bei Kreuzung von Erbsen und Bohnen. Zschr. Landw. Versuchsw. Österr. 4:641731.

28. TSCHERMAK, E. VON

1902. Ueber die gesetzmassige Gestaltungsweise der Mischlinge (Fortgesetzte Studien an Erbsen und Bohnen). Zschr. Landw. Versuchsw. Österr. 5: 781-861.

29. TSCHERMAK, E. vON

1904. Weitere Kreuzungsstudien an Erbsen, Levkojen und Bohnen. Zschr. Landw. Versuchsw. österr. 7:533-637.

30. TSCHERMAK, E. vON

1912. Bastardierungsversuche an Levkojen, Erbsen und Bohnen mit Rücksicht auf die Faktorenlehre. Zschr. Induktive Abstam. u. Vererbungslehre. 7: 81-234. 
PLATES 
Parental Varieties:

Fig. 1. Red Kidney 4370.

Fig. 2. Nagazura 4390.

Fig. 3. Long Roman 4521.

Fig. 4. Dark Red Kidney (65)31. Fig. 8. Mexican Red 4437.

\section{$\mathrm{F}_{3}$ Segregants of White Kidney $\times$ Nagazura:}

Fig. 9. Raisin black/pinkish buff ( $P M R k B l)$.

Fig. 10. Indian purple/pinkish buff ( $P M R k B l)$.

Fig. 11. Dark heliotrope slate/pinkish buff $(P M R k B l)$.

Fig. 12. Raisin black/testaceous $(P M r k B l)$.

Fig. 13. Indian purple/testaceous $(P M r k B l)$.

Fig. 14. Maroon/pinkish buff ( $P M R k b l)$.

Fig. 15. Oxblood red/pinkish buff $(P M R k b l)$.

Fig. 16. Deep hellebore red/pinkish buff ( $P M R k b l)$.

Fig. 17. Maroon/testaceous ( $P M r k b l)$.

Fig. 18. Oxblood red/orange cinnamon ( $P M r k b l)$.

$\mathrm{F}_{3}$ Segregants of China Red $\times$ Red Kidney:

Fig. 19. Raisin black/pinkish buff $\left(P \frac{R}{r} R k B l\right)$.

Fig. 20. Raisin black/testaceous $\left(P \frac{R}{r} r k B l\right)$.

Fig. 21. Oxblood red/light pinkish cinnamon $\left(P \frac{R}{r} R k b l\right)$.

Fig. 22. Oxblood red/testaceous $\left(P \frac{R}{r} r k b l\right)$.

Fig. 23. Dull violet black $(P R B l)$.

Fig. 24. Dull purplish black $(P R B l)$.

Fig. 25. Oxblood red $(P r b l)$.

F $_{3}$ Segregants of Dark Red Kidney $\times$ Red Kidney:

Fig. 26. Raisin black/light pinkish cinnamon $\left(P \frac{R}{r} R k B l\right)$.

Fig. 27. Oxblood red/testaceous $\left(P \frac{R}{r} r k b l\right)$.

Fig. 28. Black ( $P R B l)$.

Fig. 29. Indian purple $(P R B l)$.

Fig. 30. Violet carmine $(P R B l)$.

F $_{3}$ Segregants of China Red $\times$ Mexican Red:

Fig. 31. Victoria lake/testaceous, with black hilum ring.

Fig. 32. Oxblood red/testaceous, with black hilum ring.

Parental Varieties:

Fig. 33. White Kidney 4516.

Fig. 34. Red Eye 4387.

$\mathrm{F}_{2}$ Segregant of Red Eye $\times$ Buff:

Fig. 35. Buff eye.

(All natural size.) 
HILGARDIA. VOL. 12 , NO. 9

[SMITH] PLATE 1
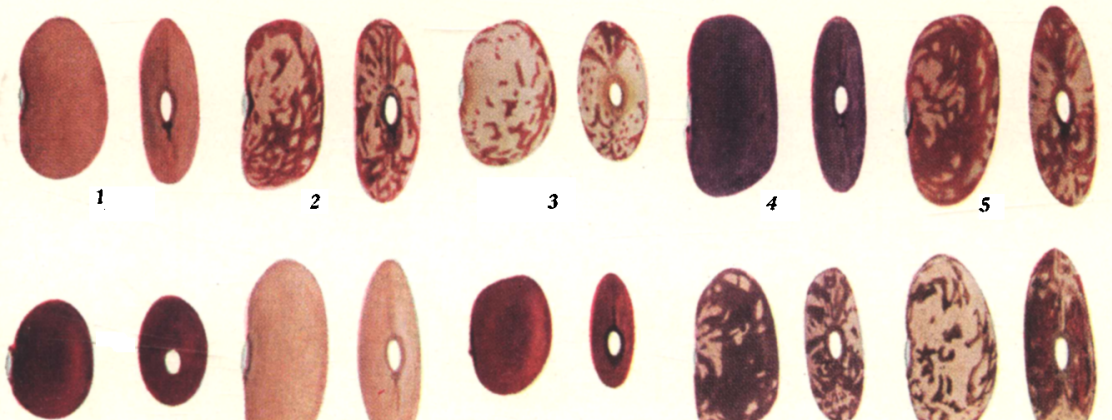

6
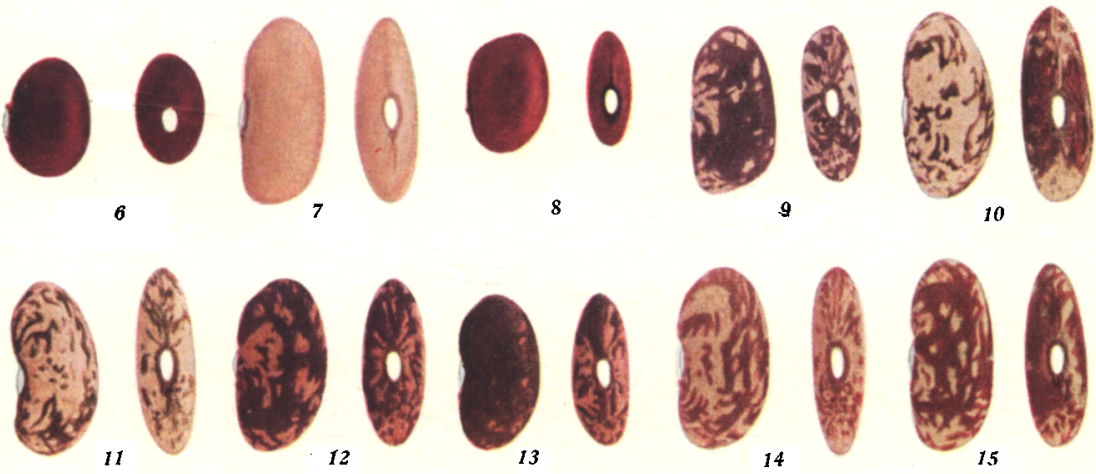

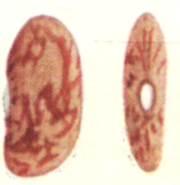

16
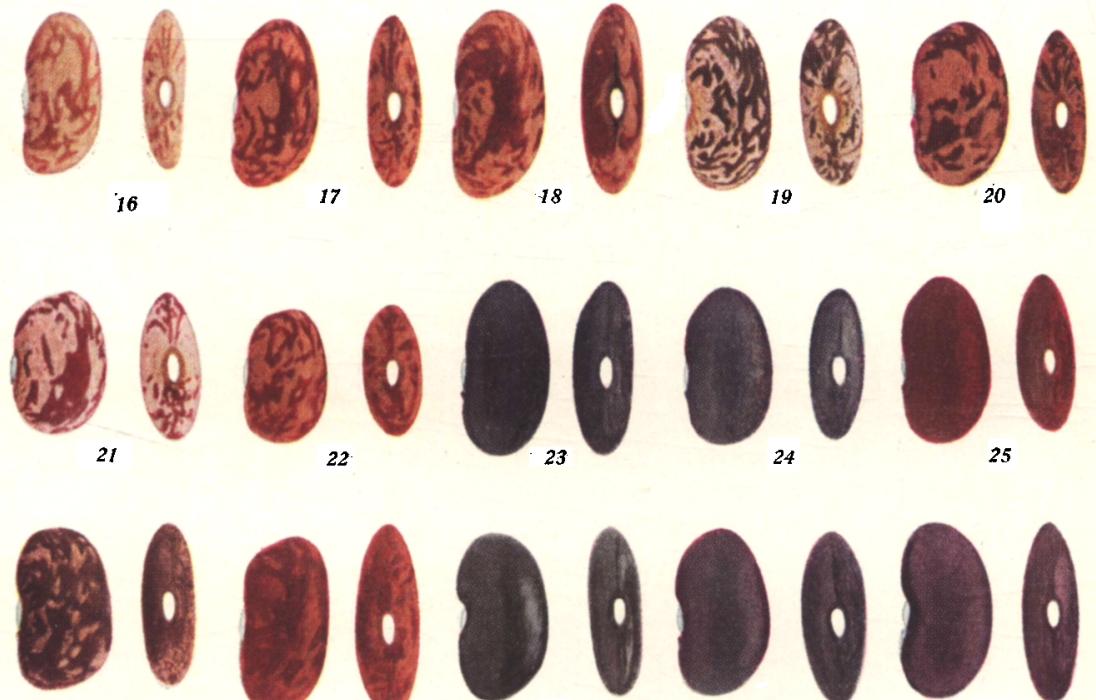

26
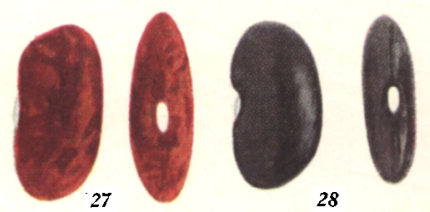

28
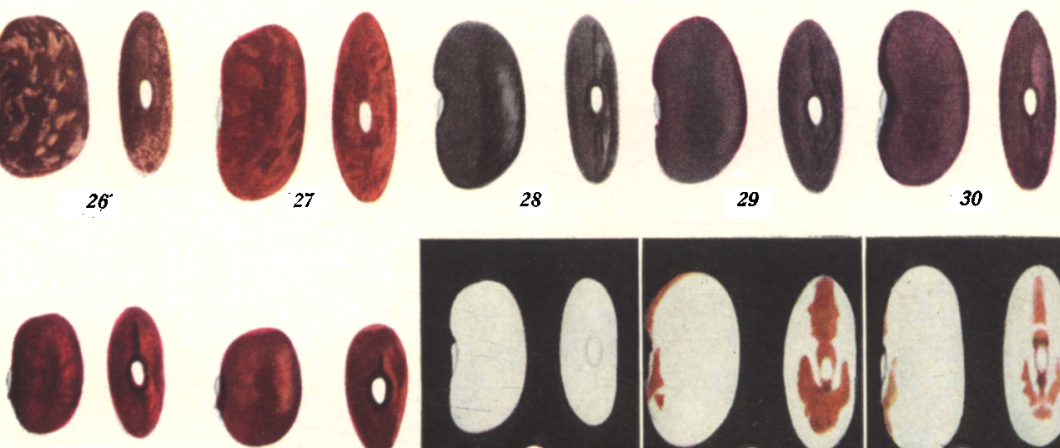

31

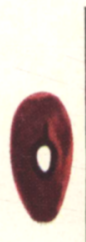

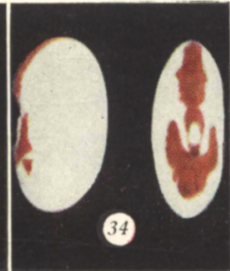

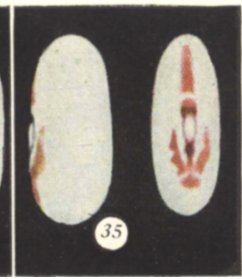

[ 619 ] 


\section{PLATE 2.}

F $_{3}$ Segregants of China Red $\times$ Mexican Red:

Fig. 36. Pompeian red/testaceous.

Fig. 37. Victoria lake, with black hilum ring.

Fig. 38. Oxblood red, with orange hilum ring.

Fig. 39. Oxblood red, with no hilum ring.

Fig. 40. Pompeian red, with black hilum ring.

Fig. 41. Victoria lake, with no hilum ring.

Fig. 42. Perilla purple, with black hilum ring.

Fig. 43. Oxblood red, with black hilum ring.

Fig. 44. Pompeian red, with orange hilum ring.

Fig. 45. Ocher red, with orange hilum ring.

\section{F. Segregants of China Red $\times$ Geneva Red Kidney:}

Fig. 46. Corinthian purple. Fig. 50. Deep Corinthian red.

Fig. 47. Liver brown.

Fig. 48. Chestnut brown.

Fig. 49. Hay's russet.
Fig. 51. Oxblood red.

Fig. 52. Vinaceous fawn.

Fig. 53. Testaceous.

F $_{3}$ Segiregants of Mexican Red $\times$ Red Kidney:

Fig. 54. Black.

Fig. 55. Victoria lake.

Fig. 56. Chocolate.
Fig. 57. Oxblood red.

Fig. 58. Vandyke red.

Fig. 59. Testaceous.

\section{$F_{3}$ Segregants of Mexican Red $\times$ Dark Red Kidney:}

Fig. 60. Indian purple/testaceous.

Fig. 61. Perilla purple/light perilla purple.

Fig. 62. Oxblond red/Pompeian red.

Fig. 63. Indian purple, with black hilum ring.

Fig. 64. Indian purple, with no hilum ring.

Fig. 65. Perilla purple, with black hilum ring.

Fig. 66. Oxblood red, with black hilum ring.

Fig. 67. Oxblood red, with orange hilum ring.

Fig. 68. Oxblood red, with no hilum ring.

Fig. 69. Acajou red, with black hilum ring.

Fig. 70. Acajou red, with orange hilum ring.

(All natural size.) 
HILGARDIA. VOL. 12. NO. 9

[SMITH] PLATE 2
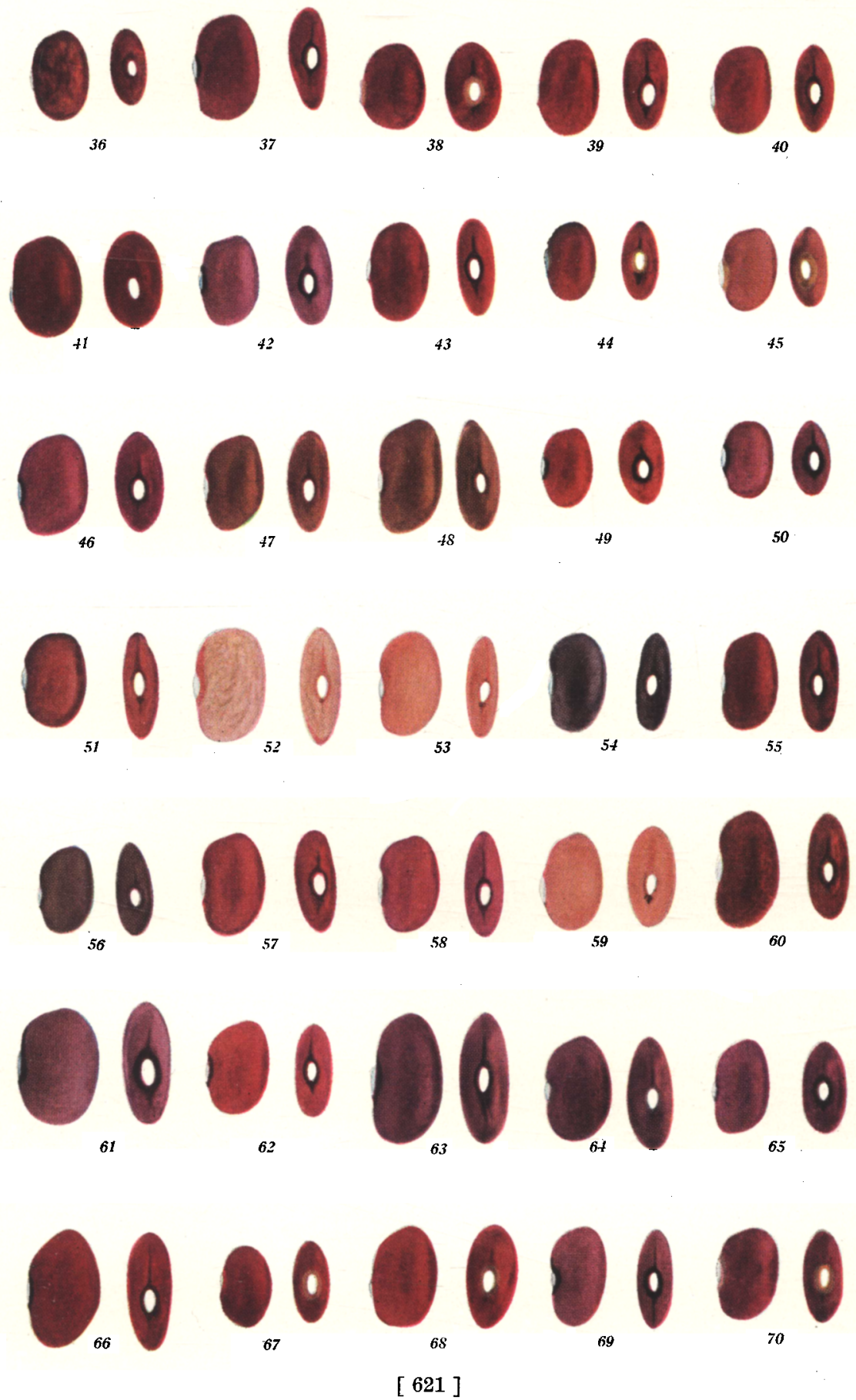
